


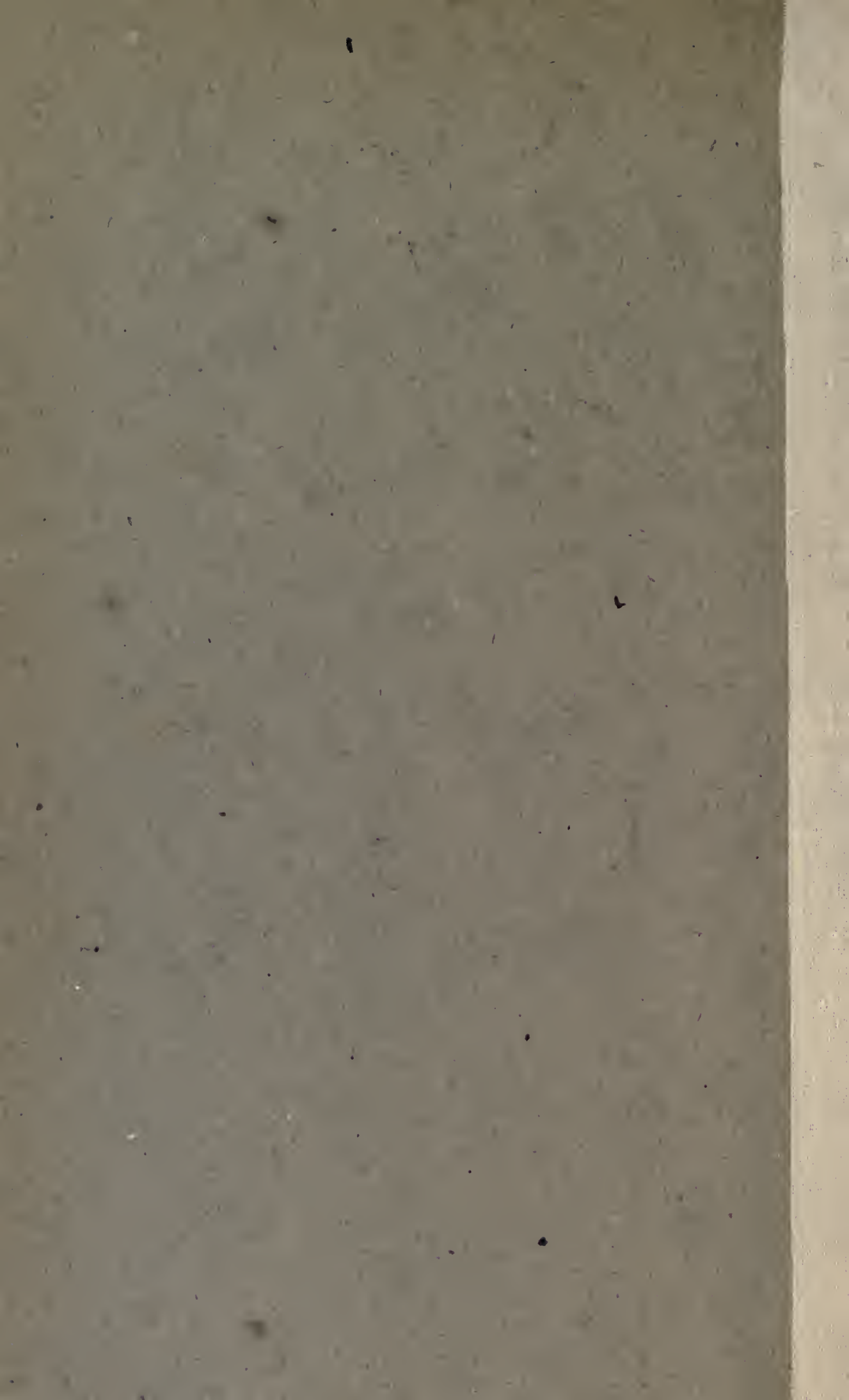




\section{DIE AMÖBEN}

insbesondere

vom parasitären und culturellen Standpunkt

ron

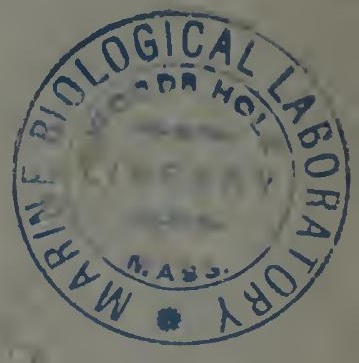

Sanitätsrath Dr. Robert Behla.

Mit einer lithogr. Thfel.

Berlin 1898.

Verlag von August Hirsehwald.

N.W. Vuter den Linden os. 


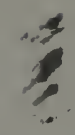

$\therefore$

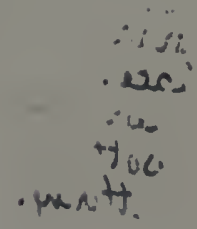




\section{DIE AMÖBEN \\ insbesondere}

\section{vom parasitären und culturellen Standpunkt}

Sanitätsrath Dr. Robert Behla.

Mit einer lithogr. Tafel.

Berlin 1898.

Verlag vón August Hirschwald. N.W. Unter den Linden 68. 
Alle Rechte vorbehalten!

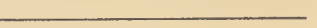




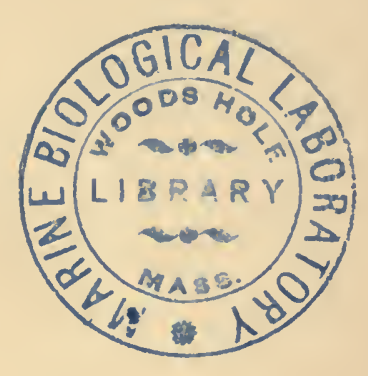

Seinem lieben Studiengenossen

Herrn Regierungs-Medicinalrath Dr. Emanuel Roth

freundlichst gewidmet

Verfasser. 


\section{Vorwort.}

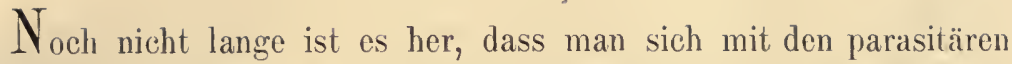
Protozoen beschäftigt; die zoologischen Lehrbücher brachten darüber nur sehr wenig, die medicinischen so gut wie garnichts. Dank der verdienstvollen Schrift L. Pfeiffer's: „Die Protozoen als Krankheitserreger", hat sich im letzten Decennium auch die Protozoenforschung Bahn gebrochen. Man ist zu der Erkenntniss gekommen, dass pathogene Protozoen in ätiologischer Beziehung zu manchen Infectionskrankheiten stehen. Einer der ersten und hervorragendsten Vertreter dieser Anschauung ist I. Pfeiffer. Nicht jede Infectionskrankheit hat ihren Grund in einem Spaltpilz. Es zeigt von Einseitigkeit, zu sagen, der Bacillus dieser oder jener ansteckenden Krankheit sei noch nicht entdeckt. Dies ist eine vorgefasste Meinung. Die Protozoenforschung ist bisher besonders den Sporozoen zu Gute gekommon. Die letzten Jahre haben mehrere Specialdarstelhungen über diese gezeitigt. Bereits 3 Schriften sind erschienen, welche sich eingehender damit beschäftigen. Es sind dies: von Wasielewski: "Sporozoenkunde", Braun: „Die thierischen Parasiten“ und Dantec und Berard: „Les sporozoaires et particulièrement les coccidies pathogènes". Die parasitären Flagellaten und Ciliaten haben bislang keine. grosse Rolle in der Pathologie zu spielen vermocht. Lindner's Vorticellen dürfte wohl eine pathogene Bedeutung abzusprechen sein. Dagegen haben die Amöben mehr von sich reden gemacht. L. P feiffer klagt gelegentlich der Besprechung der Leydenia gemmipara Schaudinn in der Münchener klinischen Wochenschrift über unsere mangelhafte Kenntniss der parasitären Rhizopoden, welche eine bedauerliche Lücke in der Welt der Kleinlebewesen darstelle. Dies und eigene Beschäftigungen mit dieser Classe der Urthierchen, sowie die aufmerksame Verfolgung der diesbezüglichen Literatur veranlassten mich, einmal Umschau zu 
halten, was an thatsächlichen Beobachtungen auf diesem Gebiete vorliegt. Bekanntlich ist die Dysenterieamöbe in den Vordergrund des medicinischen Interesses getreten und hat eine ausserordentlich reiche Casuistik hervorgerufen. Ebenso wie in der Bakteriologie sind gerade durch das medicinische Interesse erst diesbezügliche Forschungen in Fluss gekommen. Auch eine Amöbologie bahnt sich neuerdings an. Vor Allen sind italienische Forscher auf diesem Felde thätig gewesen. In Italien blühen vorzugsweise derartige Studien. Durch die biologischen Untersuchungen Celli's, Fioceas's, Casagrandi's, Barbagallo's, Grassi's ete. über Amöben, besonders durch die bahnbrechenden Arbeiten Celli's und Fiocca's über Amöbenculturen aut festem Nährboden, ist die Amöbenforschung in eine neve Phase getreten. Ihnen folgten die wichtigen Arbeiten Miller's, Beyerinck's, Schardinger's, Frosch's etc., welche diese culturelle Frage mehr vertieften und gewisse bestimmter zugespitzte Fragestellungen zur Folge hatten: Kommt den Amöben überhaupt eine krankheitserregende Bedeutung zu, wie wirken dieselben reizend auf die Zellen, scheiden sie Toxine aus, von welcher Beschaffenheit müssen ihre Nährböden sein, bedürfen dieselben zum Wachsthum und Gedeihen auf künstlichem Substrat organischer Kleinlebewesen, sind sie Gebilde sui generis oder repräsentiren manche Arten nur Durchgangsstadien anderer Protozoenclassen, wie ist die Art der Fortpflanzung bei ihrem parasitären Verhalten? etc. - Diese Punkte harren der weiteren intensiveren Bearbeitung und Klärung. Ich hielt es daher für angezeigt, die in vielen in- und ausländischen Fachzeitschriften zerstreuten Mittheilungen über Amöben und amöbenartige Rhizopoden übersichtlich zu ordnen, um einen orientirenden Leberblick über das bisher Geleistete im Allgemeinen zu geben und den augenblicklichen Stand einzelner Specialfragen zu fixiren. Nicht für den Zoologen rom Fach, als vielmehr für den Mediciner ist diese Schrift geschrieben, - gewiss nicht ohne Lücken und Mängel, wie es ein solcher monographischer Entwurf mit sich bringt. Jeder Zweig der Wissenschaft hat ja seine allmälige Entwiskelung durchzumachen. Mögen unsere Anschauungen über diese Gebilde sich mit der Zeit modificiren und amöbenhaft ändern, so hoffe ich doch, dass dieser erste Versuch einen Kern bilden wird, an dem die weitere Forschung zielbewusst ansetzen kann.

Luckau (Lausitz), im Juli 1897.

Robert Behla. 


\section{Inhalt.}

Capitel I. Eintheilung der Protozoen . . . . . . . . . . . 1 Capitel II. Die Amöben im Allgemeinen . . . . . . . . . . 5

Capitel III. Die Arten der Amöben . . . . . . . . . . . . 19

Capitel IV. Die parasitären Amöben . . . . . . . . . . . 30

Capitel V. Die Dysenterieamöbe . . . . . . . . . . . 37

Capitel VI. Die Züchtung der Amöben . . . . . . . . . . . 49

Capitel VII. Technik und Untersuchung . . . . . . . . . . 61

Capitel VIII. Literatur . . . . . . . . . . . . . . . 65 

Capitel I.

\section{Eintheilung der Protozoen.}

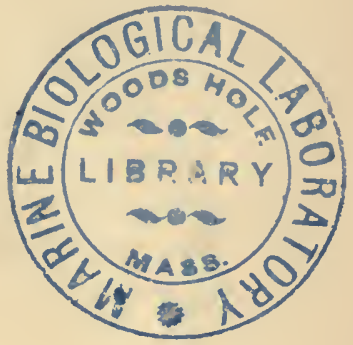

Unter Protozoen verstehen wir die niedersten thierisehen Organismen. Es sind einzellige, mikroskopische Lebewesen mit mehr oder minder eomplicirter Differenzirung des Protoplasmas und vorwiegend ungeschlechtlicher Fortpflanzung, die zuweilen Colonien bilden. Morphologisch haben sie den Werth einer Zelle. Ihre Leibessubstanz ist das Protoplasma, von welchem alle Lebensäusserungen ausgefïhrt werden. Besondere Organe, Nervensystem, Circulationsapparat ete. fehlen. Im einfachsten Falle repräsentirt das ganze Thier ein Klümpchen Sarcode, eine leicht körnig getrübte zähflüssige Substanz, welche Fortsätze (Pseudopodien) aussendet und einzieht, ohne äussere feste Haut. Bei viclen Protozoen lassen sich in der Structur 2 Schichten erkennen, das äussere hyaline Eetoplasma und das iunere körnchenreiche Entoplasma. Neist finden sich im Innern ein oder mehrere Kerne, deren Gestalt vielfach variirt. In anderen Organismen scheidet die Leibesmasse kieselige und kalkige, undurchbohrte und durchlöcherte Schalen aus, dureh welche zarte Fortsätze ausgesendet werden. Auf einer höheren Stufe treten weitere histologische Differenzirungen auf; eine äussere Membran zeigt Geisseln, Wimpern und Saugröhrehen, welche der Bewegung und Nahrungsaufnahme dienen. Die Protozoen ernähren sich im Allgemeinen von kleinen thierischen und pflanzlichen Organismen, sowic organischem Detritus durch Umfliessen, parasitische Arten häufig auf endosmotischem Wege; andere saugen durch Saugröhrchen die Beute aus. Zuweilen dient eine ausgebildete Mundöffnung zur Aufnahme der Nahrung und eine Afterstelle zum Ausstossen des Unverdauten. Bei vielen niederen Protozoen sammeln sich die auszuscheidenden Flüssigkeiten in sogenannten contractilen Vacuolen an, welche in bestimmten Pausen ihren Inhalt nach aussen entleeren. Die Vermehrung findet statt auf dem Wege der Theilung und Knospung, 
bei manchen Classen kommt Sporenbildung vor. Die Fortpflanzung ist meist eine ungeschlechtliche, doch giebt es Anklänge von amphigoner Fortpflanzung (Conjugation). Ein grosser Theil der Protozoen sind Parasiten.

Dem System der Protozoen liegt zu Grunde der Grad der organologischen und histologischen Differenzirungen, welche hervortreten in der Einrichtung zur Fortbewegung und Ernährung, daher ihre Eintheilung in Rhizopoden (Protoplasmafortsätze), Flagellaten (Geisseln), Ciliaten (Wimpern) und die durch Parasitismus in Fortbewegung, Salnung und Fortpllanzung beeinflusste Classe der Gregarinaria oder Sporozoen.

\section{Classe: Rhizopoden (Sarcodina).}

Hit einem oder mehreren Kernen. Bewegung und Nahrungsaufnahme durch Ausstossen rerschiedenartiger Fortsätze, welche lang, kur\%, stumpf, spitz, fadenförmig etc. sind. Fortpflanzung durch Theilung und Knospung, in aufsteigender Reihe werden die systematischen Ierkmale bestimmter (chitinöse, kalkige, kieselige Gehäuse). Körpergestalt erhält gesetzmässige Formen. Wir unterscheiden:

1. Unterclasse: Amoebina, nackt oder beschalt, Pseudopodien lappig und netzförmig, meist mit contractilen Vacuolen, hauptsächlich im süssen Wasser; zum Theil Parasiten.

2. Unterclasse: Foraminifera, mit meist kalkiger, einkammeriger, gewöhnlich vielkammeriger Schale, welche entweder von feinen Poren durchbohrt ist oder nicht. Durchtritt der Pseudopodien durch die Oeffnungen. Feine, spitze Psendopodien, die häufig in einander fliessen. Meist olne contractile Vacuolen. A. Imperforata. 13. Perforata.

3. Unterclasse: Heliozoa, nackt oder mit Kieselskelett, Gestalt kuglig, mit contractilen Vacuolen, mit radiär stehenden Fortsïtzen. Ecto- und Entosark. In letzterem der Kern. In den Pseudopodien ein $\Lambda$ chsenfaden.

4. Unterclasse: Radiolarien, Skelett meist kieselig oder chitinös, sehr variabel, selten fehlend. Körper durch eine Kapselmembran in äusseren und inneren Theil geschieden; in letzterem, der sogenannten Centralkapsel, die Zellkerne. Das Extracapsulum besteht aus Protoplasina und Gallerthülle, über der Oberfläche des letzteren feine weiche Pseudopodien ausstrahlend. Extra- und intracapsuläres Protoplasma in Verbindung durch Löcher in der Kapselmembran, Porulosa und Osculosa, mit 4 Ordnungen: Spumellaria, Acantharia, Nassellaria, Phaeodaria. 


\section{Classe: Flagellaten.}

Eine oder mehrere Geisseln am Vorderende des Körpers, mit contractiler Vacuole, allein lebend oder Colonien bildend. Fortpflanzung dureh Theilung oder Sprossung, zuweilen Copulation. 4 Ordnungen: Flagellata, Choanoflagellata, Cystoflagellata, Cilioflagellata (Dinoflagellata).

\section{Classe: Infusoria (Ciliata).}

Nit Wimpern oder wimperähnlichen Fortsätzen, mit Vund- und $\Lambda$ fteröffnung, contractiler Vaeuole, mit 2 Kerrien: Hauptkern oder Makronucleus und Ersatzkern oder Mikronucleus. Fortpflanzung durch Theilung, häufig Conjugation. \& Ordnungen: Holotricha, Heterotricha, Hypotricha und Peritricha. Anhang: Suctoria (Acineten), nur in der Jugend bewimpert; bei den ausgebildeten Thieren Wimpern nicht vorhanden. Kein IJund, mit contractiler Vacuole.

\section{Classe: Sporozoen.}

Einzellige, thierische Organismen, welche Keime (Sporozoiten) erzeugen; die aus Protoplasma und Zellkern bestehenden Keime haben Sichel- oder Amöboidform und sind meist einzeln oder mehrfach in beschalten Fortpflanzungskörpern (Sporen) eingeschlossen. Ohne Pseudopodien, ohne Wimpern und Geisseln, ohne Iund und After, ohne contractile Vacuole; meist mit einer Cuticula umgeben. Von grosser Mannigfaltigkeit der Gestalt. Ernährung nie durch Aufnahme fester Nahrung, sondern durch Endosmose. Sämmtlich Schmarotzer; wahrscheinlich alle - während eines Entwicklungsstadiums - Zcllschmarotzer. Weitverbreitete Parasiten. Noch nie bei Pflanzen, mehr aber in allen Thierclassen, ausgenommen bei Protozoen und Coelenteraten, angetroffen. Im Allgemeinen 3 Stadien der Entwickelung: 1. das Heranwachsen der Keime zu ausgebildeten Sporen; 2. die Aufspeicherung von Nahrungsstoffen im Entoplasma unter andauernder Grössenzunahme: 3. Vermehrung, ausschliesslich im encystirten Zustand. Eintheilung nach Wasielewski:

1. Ordnung: Gregarinen, einzellige, einkernige Zellschmarotzer, von kugliger, ovaler oder wurmförmig langgestreckter, in der Richtung der Längsachse symmetrischer Gestalt, zuweilen in $2-3 \mathrm{Ab}$ schnitte zerfallend. Von fester Cuticula umgeben, oft mit Haftapparaten versehen, ohne Vacuolenbildung. Im Jugendstadium amöboid beweglich. Ernährung endosmotisch. Vermehrung dureh Sporenbildung nach Encystirung. Zerfall in kleine Ballen, welche zu spindelförmigen Körpern werden. Die Sporen enthalten sichelförmige Keime, 
Sporozoiten, die stets intracellulär sich zu Gregarinen entwickeln. Diese leben frei im Darm oder der lueibeshöhle des Wirthes. Schmarotzer bei Echinodermen, Würmern, Gliederthieren, Molluscoiden, Weichthieren und Mantelthieren. Nie bei Vertebraten.

2. Ordnung: Haemosporidien, einzellige Parasiten des Blutes, von länglich gestreckter, gregarinenartiger Gestalt und Structur. Keim wächst im Blıtkörperchen, der erwachsene Parasit kann eine Zeit lang frei im Blute leben, dringt vor der Vermehrung von Neuem in die Zellen des Blutes. Innerhalb derselben dam Zerfall in eine Anzahl von Keimen. Schmarotzer nur bei Wirbelthieren.

3. Ordnung: Coccidien, einkernige Zellparasiten, von kugliger oder ovaler Gestalt. Unbeweglich. Thre Entwickelung läuft ganz und gar in einer Zelle ab. Der Körper kapselt sich ein und zerfällt in Sichelkeime, die entweder frei in der Cyste liegen oder in Sporenhüllen eingeschlossen sind. Endogene und exogene Keimbildung. Schmarotzer bei allen Classen der Wirbelthiere, bei Gliederthicren und Weichthieren. Massenhaftes Auftreten verursacht heftige Seuchen unter Rindern, Kaninchen, Geflügel.

4. Ordnung: Acystosporidien (Gymnosporidia), Zcllparasiten von amöboidem Bau, scheiden vor der intracellulär ablaufenden Keimbildung nie eine Hülle ab. Vermehrung durch Zerfall des kugligen Plasmaleibes in zahlreiche Keime von ovaler, amöboid veränderlicher oder sichelförmiger beständiger Form. Schmarotzer nur bei Vertebraten, häıfig bei Vögeln. Dazu die Malariaparasiten (systematische Stellung noch fraglich).

5. Ordnung: Myxósporidien, kernhaltiger, amöboid beweglicher Protoplasmaleib. Die Bildung von Sporoblasten beginnt schon im jugendlichen Individuum; in den Sporoblasten entstchen beschalte mit Polkapseln und Polfüden versehene Sporen, welche amöboide Keime einschliessen. Schmarotzer bei Würmern, Arthropoden, Eidechsen, Molluscoiden und Wirbelthieren, sehr häufig bei Fischen.

Anhang: a) Sarcosporidien, Schmarotzer der Muskelfasern, von schlauchförmiger, ovaler, bisweilen kugliger Gestalt. Ihr Protoplasma zerfällt in zahlreiche, nieren- oder sichelförmige kemhaltige Körperchen. Eine Cuticula sendet zahlreiche Septa in das Innere. Die Production von Fortpflanzungskörpern bereits vor Erreichung der vollen Körpergrösse. Ausschliesslich bei Wirbelthieren, vorwiegend bei Säugethieren, besonders bei Schafen und Schweinen. Mieschersche Schläuche.

b) Amoebosporidien, Gestalt amöboid veränderlich. Vermehrung entweder direct durch Theilung, oder nach vorhergehender 
Conjugation dureh Bildung einer Spore, welche Sichelkeime einschliesst. Stellung zu den Sporozoen fraglich (Ai. Schneider). Schmarotzer in den Nalpighisehen Gefässen einiger Käfer.

c) Serosporidien, nach I. Pfeiffer einzellige Schmarotzer aus der Leibeshöhle verschiedener Cruster, haben in der Entwickelung Aehnlichkeit mit Sporozoen. Gestalt rundlich, länglich gestreckt, oval oder spitz oval. Vermehrung entweder durch directe Theilung oder durch Abscheidung einer Hülle. Umwandlung in eine Cyste, deren Inhalt in zahlreiche Amöboidkeime zerfällt.

Capitel II.

\section{Die Amöben im Allgemeinen.}

Eine Amöbe repräsentirt im Allgemeinen ein kleines Klümpchen Protoplasma, welches aus einer äusseren körnchenfreien hyalinen Schicht und aus einer. inneren körnchenreichen dunkleren Masse besteht, an seiner Oberfläche Pseudopodien nach aussen vorstreckt, meist mit Kern und contractiler Vacuole versehen, bald nackt, bald beschalt ist.

Die bei den Rhizopoden überhaupt beobachteten Schalen sind in Bezug auf das Material, aus dem sie aufgebaut sind, chitinöse, Kalk-, Fremdkörper- oder kieselige Schalen.

Die auf chitinöser Grundlage durch secundäre Imprägnation und Auflagerung von kohlensauren Kalk entstandenen, complicirteren Kalkschalen, welche gewöhnlich den marinen Formen angehören, sowie die aus Kieselsäure bestehenden Schalen, deren Existenz noch zweifelhaft ist, lassen wir hier ausser Betracht. Bei den beschalten Amöben, vorwiegend Süsswasserformen, interessiren uns hauptsächlich die chitinösen und Fremdkörperschalen.

Die aus reiner Chitinmasse zusammengesetzten Schalen lassen keine besondere Structur erkennen, sind dünn, zart, biegsam und liegen in der Regel dem inneren Plasmakörper dicht an, z. B. bei Gromia, Leeythium, Lieberkühnia. Höchstwahrscheinlich verdanken sie ihr Dasein einer Secretion oder chemischen Umbildung der äusseren Plasmamasse. Die Schale kann aber auch dicker werden durch Auflagerung auf die äussere Fläche der Wandung. Während bei den 
marinen kalkschaligen Organismen der Weichkörper den Innenraum meist ganz ausfüllt, weicht bei den starrschaligen Süsswasserformen die Plasmamasse etwas von der Wandung zurück; dann befindet sich dazwischen eine Flüssigkeit. Zuweilen ist der innere Weichlkörper an der Mündung der Sehalen festgeheftet, z. B. bei Mierogromia, Platoum, manchmal halten kleine Fortsätze am Hinterende die Innenmasse mit der Schale zusammen, wie z. B. bei den Lobosen: Areella, Hyalosphenia, Quadrula, Difflugia und unter den Reticulosen bei Cyphoderia.

Ausser diesen structurlosen, homogenen Chitinschalen giebt es aber auch solche, welche eine feinere Structur auf der Oberfläche erkennen lassen, sei es dass kleine Höekerehen, eine zarte Strichelung, oder eine reticuläre Zeichnung darauf zu sehen ist.

Eine noch complicirtere Structur haben die aus Plättchen aufgebauten Sehalen. Letztere, deren chemische Natur noch zweifelhaft ist, sind entweder rundlich, seheibenförmig, dicht aneinander oder übereinander liegend, wie z. B. bei Trinema, oder sie sind ron vierund mehreckiger Form, viereckig bei Quadrula, sechseckig bei Euglypha. Sie stehen in mehr oder weniger festem Zusammenhang. Ihre Anordnung geschieht in ziemlich regelmässigen Reihen, die entweder nach der Längs- und Querrichtung verlaufen (Quadrula) oder schief zur Sehalenaxe stehen (Trinema). Bei manehen Formen zeigen diese Plättchen am Hinterende stachelartige Fortsätze, z. B. bei Quadrula; bei Euglypha erseheinen sie an der ganzen Oberfläehe, auch am Mïndungsrande, weshalb derselbe gezackt ist. Bei Areellasehalen beobachtet man zwei übereinander gelagerte Schichten, eine dünnere, innere, structurlose und eine äussere, dickere, mit reticulärer Zeichnung, bestehend aus einzelnen hexagonalen Feldehen. - Die Farbe der structurlosen Schalen ist homogen, hell, farblos, der structurirten im Allgemeinen gelblich, gelb, zuweilen braun (Arcella).

Die sogenannten Fremdkörperschalen werden dadureh herrorgebracht, dass die ursprünglich ausgesehiedene chitinöse Hülle zur Verstärkung verschiedenartige feste Partikelehen aufnimmt und mit einem Kitt verbindet. Diese Theilehen sind vorwiegend kleine Sandkörnchen, besonders Quarztheilehen, die Kieselhüllen der Bacillariaceen etc. (kieselsandige Schalen). Die eigenthümliche Schalenstructur maneher Difflugien bestehen in kleinen eylinder- oder mannigfach gebogenen stäbchenartigen Gebilden, welehe hexagonalen oder scheibenförmigen Plättchen ähnlich sind. Nach Wallich's Ansicht sind dies von aussen aufgenommene Diatomeensehalen, welehe dureh active Linwirkung des Plasmas eine Umwandlung erfahren haben. 
Nebenbei sei bemerkt, dass auch die kalkhaltigen Schalen der marinen Formen Fremdkörper aufnehmen. Dazu werden verwendet Neerkalksand, Schwammnadeln, Kalkschalen von Coccolithen etc. Was schliesslich den Kitt der Schalen der Süsswasserformen anbelangt, so ist derselbe im Allgemeinen chitinöser Natur, andererseits dient vielleicht auch als Kitt ein protoplasmatisches oder gallertiges Bindemittel. Hanche Amöbenforscher wollen zwischen den Fremdpartikelchen cin Hervorquellen kleiner Pseudopodien beobachtet haben.

Die morphologisehe Gestaltung der beschalten Süsswasserformen ist fast durchweg einachsig, die Form sack- bis eiförmig, durch röhrige Verlängerung des die Mündung tragenden Pols mehr flaschenförmig. Bei Arcellinen, Euglyphinen, Gromiinen zeigt sich gewöhnlich eine runde Contour, zuweilen jedoch tritt durch Abplattung in ciner der Längsachse parallelen Ebene eine zweistrahlige Form auf, auch Hinneigung zur bilateral symmetrischen Gestaltung, sogar eine spiralige Einkrïmmung der Schalenhauptachse ist constatirt worden (Difflugia spiralis).

Die Amöben kommen vor im süssen und Neerwasser, auch in der Erde und luft sind sie verbreitet. Man unterscheidet marine und Süsswasscramöben; nur wenige Formen haben ihr Gedeihen in beiden Medien. Gefunden wurden Amöben bisher im bebauten Erdboden, im feuchten Sand, auf Wiesen, im Sumpf und Moor, im Trinkwasser, im Nineralwasser, im Kanalwasser, im Flusswasser, in unreinen Brunnen und Teichen, besonders im Schlamm, ferner im Hoos auf Bäumen, im feuchten Moos von Dächern, im Dachrinnensand ete. Beschalte Formen wohnen mit Vorliebe im Wasser auf Steinen und Pflanzen. In fauligen Medien scheinen nur wenige Species dauernd existiren zu können. Ausserdem begegnet man ihnen im Darm und anderen Theilen von Thieren und Mensehen. Sie leben im kalten und warmen Wasser, ja sogar in den heissen Quellen von Civita vecchia, Abano und Ischia sind sie vertreten. In verhältnissmässig grosser Tiefe trifft man sie noch im Erdboden, sic wurden noch zwei Neter tief constatirt; aber auch auf Bergeshöhen haben sie ihren Wohnplatz. Celli und Fiocea fanden Amöben in 4500 Fuss Höhe, Perty in den Alpen Difflugien in 8000 Fuss, Ehrenberg im Himalaya Arcella und Euglypha in 5000-8000 Fuss, Leidy wies nach, dass die Rhizopodenfauna in Rocky-Mountains bei 10000 Fuss Höhe fast denselben Charakter trägt, wie in Philadelphia. Was die geographische Verbreitung anbelangt, so sind Amöben auf der ganzen Erde verbreitet. Einzelne Arten sind Kosmopoliten. In den nördlichen Strichen scheinen wach den bisherigen Untersuchungen dic Arten weniger 
zahlreich zu sein, als in den wärmeren Gegenden. Unser Wissen über die Verbreitung der einzelnen Species ist noch beschränkt und lückenhaft; aus einer Tabelle von Bütschli geht hervor, dass speciell manche Formen, wie Arcella, Difflugia, Hyaolosphenia, Quadrula, Euglypha etc. mehr oder weniger in allen Continenten angesiedelt sind.

Die Grösse der Amöben ist variabel, sie schwankt zwisehen $0,5 \mu$ bis $14 \mu$ und darüber. $\mathrm{Zu}$ den kleinsten Formen gehören Amoeba diaphana $(0,5-2 \mu)$ und Amoeba guttula $(1-2 \mu)$; zu den grössten Pelomyxa (bis $2 \mathrm{~mm}$ gross).

Die Gestalt der Amöben wechselt, daher der Name. Bewegliche nackte Formen zeigen keine Formbeständigkeit, beschalte sind an eive gewisse Constanz gebunden durch die mehr oder weniger starre Hülle. Ruhende nackte Amöben neigen in Durehschnitt zur Kugelform.

Die Bewegungsart der Amöben ist rerschieden, eine fliessende, wellenförmige oder kriechende, durch das Ausstrecken und Einziehen der Fortsätze bedingte. Dic fliessende Bewegung findet statt bei einigen Amöben, die keine Pseudopodien entwickeln, sondern mit der gesammten Leibesmasse, ohne eintretende Gestaltsveränderungen, fortrücken. So fliesst die abgeflaehte, scheibenförmige, nahezu runde Amoeba guttula tropfenartig nach einer gewissen Richtung; in ähılicher Weise fliesst die mehr bandartig gestreckte Amoeba Limax ohne Pseudopodienbildung; auch die Pelomyxa ändert lıäufig in dieser Weise ihren Platz. Die wellenförmige Bewegung zeigt Amoeba undulans in der schnellen Wellung der Contour, ohne dass besondere Fortsätze ausgestreckt werden. Sehr mannigfaltig ist die mehr kriechende Ortsveränderung durch Pseudopodien. Diese zeigen im Grossen und Ganzen zwei Hauptunterschiede, lobose Fortsätze: stumpf, kurz, breit, ohne Anastomosirung und reticuläre: lang, dünn, netzförmig, verzweigt. Sie repräsentiren jedoch nicht zwei scharf getrennte Gruppen, es finden auch Uebergänge statt, ja manche Species treiben Scheinfüsse beiderlei Gestalt, z. B. Amoeba radiosa. Wenn gleichzeitig von dem gesammten Rand des scheibenförmigen Körpers Fortsätze entstehen, so erhält die Amöbe ein strahliges Aussehen, wie Amocba polypodia (Dactylosphaera). Sie sind spitz bei der Amoeba spinosa. Bei Amoeba arboreseens sehen wir Zweige, die in einem Punkte zusammenlaufen, aber nicht unter einander anastomosiren. Bei Amoeba vermicularis zeigt sich die Bewegung besonders in einer seitlichen Beugung, so dass die Amöbe einen Bogen bildet, ein S oder einen Vrinkel und sich dann zusammenknäuelt, um sich wieder 
7u strecken, zum Haken zu krümmen etc. Die Enden der Pseudopodien können sich ferner zersehlitzen wie bei Amoeba lacerata. Sie vermögen sich auch am Ende schwimmhautartig zu verbreitern (Petalopus) und noch merkwürdigere membranartige Fortsätze schen wir bei Placopus, die sich in verschiedener Richtung vom Körper erheben, unter sich winklig zusammenfliessen und so trichterförmige $\mathrm{H}_{0} \mathrm{l}$ räume zwischen sich lassen. Wenn sich die imneren dünnen, ausgesponnenen zarten Fäden mehrfach verästeln, so haben wir das Bild der Amoeba reticulosa, die in geringerer Zahl bei einigen Süsswasserformen (Mierogromia, Lieberkühnia), vor'zugsweise bei den marinen Formen vorkommen. Zuweilen, bieten manche Species in feinen langen Fäden das Bild schwingender Geisseln dar (Podostoma). Auch finden wir merkwürdiger Weise am Hinterende einiger Amöben kurze Franzen oder haarartige ectoplasmatische Fortsätze, welche einen starren Eindruck machen, wie z. B. Amoeba monociliata Carter. Mitunter beobachtet man stachelartige Fortsätze an der ganzen Oberfläche (Chaetoproteus), so ist die Oberfläche von Dactylosphaera vitr. Hertw. u. Less. mit Protoplasmazöttchen besetzt. Gallertige Umhüllungen des Amöbenkörpers sind ein seltenes Vorkommniss. Amphizonella lässt eine ziemlich dicke hyaline Umhüllungssehicht erkennen, welche von fingerförmigen Pseudopodien durchbohrt wird etc.

Die inneren Vorgänge bei der Bewegung der Amöben stellen sich folgendermaassen dar; zunächst bei der fliessenden Bewegung von Amoeba Limax erscheint eine Strömung des Plasmas von hinten nach vorn, dort angekommen geht dieselbe rückwärts zu beiden Seiten des Körpers. Ungefähr in der Nitte macht dieselbe Halt und es tritt ein relatives Ruhestadium ein. Darauf wird diese ruhende Partie wieder in den nach vorwärts rüekenden Strom hineingezogen, so dass also eine Art Circulation des Leibesplasmas entsteht und eine fliessende Bewegung damit verbunden ist. - Beim Ausstrecken eines Fortsatzes richtet sich die Strömung des Plasmas nach einer local beschränkten Stelle, die Oberfläche wölbt sich als Höeker hervor, zuerst die hyaline Schicht, dann folgt das Körnerplasma nach. Nun bewegt sich das Plasma in dem axialen Theil des Fortsatzes vorwärts und fliesst am Ende desselben nach den Seiten ab. Indem dieses sich in der Mitte in einem fast ruhenden Zustand anhäuft, wäehst durch andauernden inneren Zufluss das Pseudopodium in die Länge. Letzterer hört schliesslich auf und dadurch, dass sich an einer anderen Stelle der Oberfläche ein Höcker vorwölbt, zieht sich der Strom in den ersten Fortsatz zurück, es tritt eine Verkürzung ein und nach einiger Zeit ist derselbe wieder ganz in die Leibesmasse aufgenommen. So bietet 
Finziehen und Ausstrecken der Seheinfüsse ein wechselndes interessantes Spiel dar. Wenn hyalines und körniges Plasma gesondert ist, so ist der Strom in dem Fortsatz zuerst hyalin, die körnige Mlasse rückt nach. Bei solchen Species, wo keine deutliche Scheidung vorhanden ist, besteht das Pseudopodium aus feinkörnigem Plasma, wie \%. B. bei den beschalten Amöben Difflugia, Hyalosphenia ete. - Fin ausgezeichnetes Object für die Bewegung des Plasmas in netzförmig ver\%weigten Fïden giebt uns die Gromia oviformis, welche in verschiedenen Arten im süssen und salzigen Wasser vorkommt. Aus der weiten Mündung des einen Pols des ovalen Gehäuses dringt das körnige Protoplasma hervor und überzieht die Oberfläche in dünner Schicht. Von diesem nun strahlen feinste Fädchen nach allen Richtungen, manche gabeln sich, andere lösen sich in zahlreiche Fädehen auf und geben Seitenzweige ab, dureh welche sie sich mit benachbarten Pseudopodien verbinden. Bei der mikroskopischen Beobachtung zeigen auch die kleinsten Füdchen Bewegung. Mehr oder weniger schnell geht eine Strömung entweder der Peripherie zu oder in umgekehrter Richtung, nicht selten in manchen Fäden vor- und rückwärts. Nicht alle Körnchen eines Fadens laufen gleich sehnell. Viele, sagt II ax Schulze in seiner trefflichen Schilderung dieses Vorganges, laufen offenbar an der äussersten Oberfläche der Fäden, über welche man sie deutlich hervorragen sieht. Oft bemerkt man auch grössere Substanzklümpchen mit spindelförmigen Anschwellungen oder seitlichen Auftreibungen eines Fadens in ähnlicher Bewegung wie die Körnchen. Selbst fremde Körper, welche der Fadensubstanz anhaften und in sie aufgenommen werden, schliessen sich dieser Bewegung an, deren Gesehwindigkeit bis $0,02 \mathrm{~mm}$ in der Secunde erreichen kann. Wo mehrere Körnchen zusammenstossen, sieht man die Körnchen von einem auf den anderen übergehen. An solehen Stellen befinden sich oft breitere Platten, welche aus einer stärkeren Anhäufung der Fadensubstanz hervorgegangen sind. Was die Sehnelligkeit der Ortsveränderung der Amöben im Allgemeinen anbelangt, so ist dieselbe träge und lebhaft, je nach der Dicke des Eetoplasmas und der dichteren oder dümneren Consistenz des Plasmas. Junge Amöben bewegen sich schneller als ältere. Die grösseren in der Erde lebenden Formen mit zäherer Consistenz nehmen nur langsame Ortsveränderungen vor. Man hat berechnet, dass die Amöben im Durchschnitt in einer llinute eine Wegstrecke von $1 / 2 \mathrm{~mm}$ zurücklegen können.

Ueber die feinere Struetur des Weichkörpers sei Folgendes angeführt. Ecto- und Entoplasma sind an Masse sehr variabel, dünn und \%ähıllüssig, fein und stark gekörnt. - In der Mch»\%ahl sind bei 
nackten Amöben beide Schichten vorhanden, manchmal ist das hyaline Plasma minimal, kann auch ganz fehlen. Beschalte Amöben zeigen im Allgemeinen wenig Differenzirung in Ento- und Ectoplasma, noch weniger marine.

Im Durchschnitt bergen Amöben im Innern einen Kern, derselbe ist bläschenförmig, kugelig, ellipsoidisch oder scheibenförmig abgeplattet, mit Kernkörperchen. Manche Formen entbchren desselben, \%. 13. Amoeba diaphana und reticularis. Celli und Fiocea berichten, dass sie niemals 2 Kerne in Amöben gesehen haben. Dies wird jedoch mehrfach bestätigt. Bei Arcella und Difflugia sind mehrere vorhanden, deren Zahl schwankt. Die Lage derselben ist: verschieden.

Im Innern des Amöbenplasmas werden ferner angetroffen nicht contractile Flüssigkeitsräume, sogenannte Vacuolen, variabel an Grösse und Zahl. Bei Amoeba spinosa bemerkt man 1-7, welche Form und Platz bei den Bewegungen wechseln. Zuweilen treten so viel auf, dass dadurch ein schaumiges oder alveoläres Aussehen bedingt ist, z. B. bei der von Mereschkowsky beschriebenen Amoeba alveolata. Daneben kommen häufig contractile Vacuolen vor, die sich durch Contraction des umgebenden Plasmas zusammenziehen und verschwinden, in regelmässigen Intervallen; sie haben wahrscheinlich im Dienste der Athmung und Excretion eine wichtige Function. Lage und Zahl schwankt. Bei Arcella hat man 1 bis 12 getroffen. Claparède und Lachmann zählten in manchen Formen bis 20.

Auch Gasvacuolen finden sich, die schnell entstehen und vergehen, z. B. bei Arcella. Die Natur des Gases ist nicht klar. Bütschli vermuthet Kohlensäure, wegen der raschen Absorption durch Kalilauge. - Es existiren weiter im Endoplasma feinkörnige Pigmente, rothe, gelbrothe, gelbbraune etc. Ein tiefviolettes Pigment besitzt Amphizonella violacea. Zinnoberroth, zuweilen braunroth ist dasselbe bei Placopus ruber. Nanche haben grüne Kerne, z. B. Dactylosphaera vitr. Hertw. u. Less. Mitunter zeigen sich zahlreiche Chlorophyllkerne, welche von aufgenommener Nahrung herrühren; sie sind kein endogenes Erzeugniss des Amöbenkörpers. $\Lambda$ usser gefärbten kernigen Einschlüssen sind zu nennen kleine stark lichtbrechende Fettkügelchen, ferner dunkle Kernchen von äusserster Kleinheit mit unregelmässigen Formen, zuweilen auch krystallinischer Bildung, deren chemische Natur zweifelhaft ist. Bütschli fasst sie als Exeretkörner auf. Der sogenannten Glanzkörper gedenken wir später.

Die Ernährung der Amöben geschieht durch Aussenden der Pseudopodien und Aufnehmen von festen Partikelchen, wie Gewebs- 
trümmer, Bacterien, Blutkörperchen ete. Auch Theilchen ohne Nährwerth werden aufgenommen, wie Carmin- und Zinnoberkernehen. Unverdautes wird wieder ausgestossen. Hat ein Pseudopodium ein Körperchen berührt, so umfliesst es dasselbe, verkürzt sich und inkorporirt es allmälig in die Hauptmasse des Plasmas. Interessant ist das Spiel der Aufnahme von Fremdkörpern bei netzförmigen Fortsätzen. Es bilden sich plattenartige Anhäufungen an den Fäden, las Körperchen wird umflossen, die Fäden eontrahiren sich, bis die Nahrung in den Körper aufgenommen ist.

Die Vermehrung der Amöben findet statt durch Theilung, Sprossung und möglicherweise durch endogene Sporenbildung.

Die Theilung erfolgt bei nackten und beschalten Amöben in der Regel ohne vorhergehende Befruchtung. Sie lässt sich unter dem Mikroskop genau beobachten. Die Zeitdauer dieses Vorganges ist verschieden, sie währt ca. 10 Ninuten bis 1/4 Stunde. Bei manchen Formen ist die Vermehrung eine schnelle, fast so rasch wie bei Schizomyceten, z. B. Amocba reticularis. Wie Celli und Fiocea bei ihren Culturen beobachteten, ist die Theilung theilweis sehr lebhaft, die Exemplare werden feiner, aus einem bilden sich 2 Elemente, die scheibenförmig, birnenförmig, rundlich sein kömen und durch äusserst feine Fäden vereinigt sind, diese zerreissen später, so dass die Theilstücke selbstständig werden. Bei anderen Amöben spielt sich die Vermehrung langsamer ab, z. B. bei Amoeba arborescens. Es ist lange eine Streitfrage gewesen, ob der Theilung der Individuen eine Theilung des Kerns vorausgeht. Celli und Fiocea gestehen, dass sie selbst bei den grössten Amöben gelegentlich ihrer Culturversuche dies nicht zu entseheiden vermochten. In der Amöbenliteratur sind jedoch mehrfach sichere Beobachtungen im bejahenden Sinne beschrieben. Der Vorgang wurde von F. E. Schulze unter dem Mikroskop genau verfolgt bei Amoeba polypodia; er spielte sich innerhalb 10 Minuten ab. lis ging eine Einschnürung des Kerns vorher, derselbe wurde hantelförmig und ging in 2 Theile auseinander; dann kam erst die Theilung des Plasmaleibes an die Reihe, es bildeten sieh zwei je einen Kern enthaltende Theilstücke. So konnte femer Beyerinek bei seinen Culturen von Amoeba zymophila constatiren, dass die beiden Theile, der Kern vorn und die pulsirende Vacuole diesem nachfolgend sich voneinander entfernen. Er sagt bei dieser Gelegenheit: „Offenbar hat der Kern sich zunächst getheilt, die Vacuole erst nachträglich. Dass die Vacuole sich in diesem Falle durch Einschnürung theilt, habe ich sicher beobachtet, doch kounten wälırend dieses Vorganges die Nebenvacuolen nicht gesehen werden. 
Die nicht pulsirenden Vacuolen entstehen unabhängig von den pulsirenden nicht durch Theilung, sondern spontan an unbestimmter Stelle im Körwerplasma" ete. - Bei beschalten Formen tritt, nach vorhergehender Neubildung von kleinen uhrglasförmigen Schalenplättchen im Innern, das Plasma in Form einer von jenen bedeckten Knospe aus der Oeffnung hervor, z. B. bei Englypha. Dann umgiebt sich der Sprössling ausserhalb mit einer Schale und entwickelt sieh. zur Grösse und Gestalt des Mutterorganismus. Bei sehr dünnbeschalten Formen, bei denen der Weichkörper dicht anliegt, kann eine Theilung mitsammt der Schale stattfinden, z. B. bei Amoeba Lieberkühnia.

Ausser der Vermehrung durch Theilung findet auch vielfach Knospung oder Sprossung statt. Die kleinen knospenartig abgesehnïrten Theile wachsen allmälig zu grösseren Exemplaren heran. Einige Arten zeigen beide Vermehrungsweisen. Nanche Formen bilden auch coloniale Verbände, wie Microgromia socialis, Lecythium etc. Die einzelnen Nitglieder bleiben in lebendiger Verbindung durch protoplasmatische Pseudopodienfüden.

Dass Verschmelzungen von Individuen bei Amöben vorkommen, ist beobachtet worden. Ob dieses Phänomen aber mit dem Vermehrungsprocess im Zusammenhang steht, ist noch zweifelhaft. Einige Autoren treten allerdings für diese Ansicht ein. Carter, Greeff etc. sind der Ieinung, dass die bei Arcellen und Difflugien gesehene Conjugation die Einleitung zur Entwicklung von Geschlechtsprodueten ist. An Stelle des Kerns sollen sich zahlíreiche kleine kuglige, bläschenförmige Körperchen bilden und in das Protoplasma austreten (Fortpflanzungszellen). Auch Buck und IIaggi wollen die Ausbildung zahlreicher körnchenartiger Sporen nach der Copulation verschiedener Amöben gesehen haben. Einige Forseher hingegen fassen diese Beobachtungen als einen vielkernigen Zustand der Amöben auf und verwerfen die Sporenbildung als irrthümliche Dentungen. Jedenfalls ist dieser Vermehrungsmodus noch zweifelhaft. Hierher gehört auch die Vermehrung durch Theilung innerhalb der Cysten. Wallich, der über die Fortpllanzung der Amöben viele Untersuchungen angestellt hat, lässt dieselbe ausser durch Theilnng und Knospung vor sich gehen: 1 . durch directes Lebendiggebären kleiner schon vollständig entwickelter Amöben, 2. durch Entwicklung von ihm Sareoblasten genannter Inhaltskörner des Amöbenleibs zu jungen Amöben mit oder ohne gleichzeitige Eneystirung des Mutterkörpers, 3. durch Zerfall der Sarcoblasten in die sie constituirenden Körner und dureh Entwicklung dieser zu jungen Amöben. - Es sei hier noch gedach 
der sogenannten Glanzkörper Greeff's, welche er mit der Fortpflanzung der Pelomyxa in Verbindung bringt. Diese sind von g]änzender, homogener Beschaffenheit; auf der Oberfläche erscheint eine kapselartige, glänzende Hüllschicht. Gestalt und Grösse sind variabel, im Allgemeinen herrseht die lingelgestalt vor, aber auch ovale und ganz irreguläre werden bemerkt. Greeff vermuthet, dass dieselben aus den freigewordenen Kernkörperchen der zahlreichen Kerne hervorgehen und schliesst aus den bisquitähulichen Gestaltungen, dass sie sich selbstständig vermehren können.

Die Frage der endogenen Sporenbildung der Amöben ist auch hente noch nicht endgültig gelöst. Celli und Fiocea, welche wohl die meisten Züchtungen bislang angelegt haben, betonen ausdrïcklich, dass sie stets nur Vermehrung durch Theilung bemerkt haben. Beyerinck erwähnt Sporenbildung bei der von ihm cultivirten Amoeba nitrophila. Celli und Fiocea fassen diese nur als Cystenzustand auf, "welcher von Beyerinck Sporen genannt wird". Letzterer aber betont ausdrücklich die Sporenbildung ron 1, 2 bis 3 Sporen im Innern seiner Amöben; er sagt wörtlich: „Dabei kann nicht an Eneystirung gedacht werden, weil nur ein Theil der Körpersubstanz für den Process in Anspruch genommen wird."

Diese Erage zum Austrag zu bringen, ist für die Zukunft von der grössten Wichtigkeit. Mehrfach wurden in den Cysten von Amöben kleine Körner gesehen, welche ron rerschiedener Seite als Sporen gedeutet worden sind, so z. B. auch bei Amoeba coli. Nach Grassi scheint während der Eneystirung der letzteren eine Vermehrung einzutreten. In Bezug auf Amoeba coli ist folgendes Experiment auffallend: Abgesehen davon, ob die Amoeba coli der wirkliche Erreger der Tropendysenterie ist, liessen Kruse und Pasquale amöbenhaltige Dejectionen eine Stunde lang frieren in einer Kältemischung, nach dem dufthauen konnten in ihnen keine Amöben, auch keine Cysten mehr entdeckt werden und dennoch entstand nach Einverleibung derselben in den Katzendarm eine hämorrhagische Enteritis "mit reichlicher Bildung von Amöben". Nach dieser Beobachtung fragt man sich, giebt es in der That ausser dem Cystenzustande noch einen anderen Dauerzustand zur Erhaltung der Art? Gehört dazu eine vorhergehende Conjugation? Geschieht diese nur bei cinzelnen Individuen und unter welchen Umständen? Dies sind Punkte, welche in der Folgezeit näher erörtert werden müssen.

Es hängt diese Frage innig zusammen mit der möglichen Existenz von einzelligen Organismen, die eine Mittelstellung einnehmen zwischen Amöben und Sporozoen, Wer sich genauer mit den kleinsten Lebe- 
wesen beschäftigt hat, weiss, dass sich die einzelnen Gruppen vielfach miteinander berühren. Es giebt in der That Uebergangsglieder. So bildet der Soor ein Uebergangsglied zwischen den Faden- und den Sprosspilzen. Er tritt unter bestimmten Ernährungsverlältnissen, z. B. auf zuckerreichen Substraten in hefeartiger Form als ausgesprochener Sprosspilz auf, bildet dagegen unter anderen Bedingungen, z. B. in der Tiefe der Reagenzglaseulturen, lange, fadenförmige Mycelien. Aehnliches ereignet sich unter den Protozoenclassen. Nicht bloss Anklänge an Bildungen pflanzlicher Natur, wie bei den Vycetozoen, findet man hier, es wird auch beobachtet, dass Flagellatenzustände in amöboide Formen ïbergehen. Ai. Schneider hat ron ihm sogenannte Amoebosporidien beschrieben, deren Stellung noch dunkel ist. Noch unaufgeklärt sind auch die Verhältnisse des Parasitismus. Werden ausserhalb des Körpers freilebende Rhizopoden durch das Anpassen an andere Lebensbedingungen zu anderen Vegetationsformen gezwungen? Nanche Form, die wir im Körper beobachten, ist vielleicht nur als Durchgangsstadium, als bewegliche amöboide Vegetationsform eines anderen Protozoons oder Ifycetozoons aufzufassen. Nur Züchtungen werden uns schliesslich darüber Klarheit verschaffen. Im Hinblick aut die bisher nieht geglückte Zïehtung des Malariaparasiten ete., dürfte es nach meiner Meinung empfehlenswerth sein, die Züchtung nicht aus dem regetativen Stadium, sondern aus dem trockenen Material zu versuchen. Dabei ist zu bedenken, dass Colonien im Sinne von Schizomyceten kaum zu erwarten sind, da ein Sporenkeim doch nur zu einem Schwärmer oder einer amöboiden Form, also zu einem beweglichen Dinge auswachsen kann. Vielleicht sind hierzu mehr flüssige Nährböden geeignet.

Wir betrachten noch das Cystenstadium der Amöben. Die nackten Formen pflegen sich nach einiger Zeit zu encystiren. Sie ziehen bei diesem Ruhestadium die Pseudopodien ein, werden kuglig, weniger beweglich und scheiden sehliesslich eine Hüllhaut aus. In diesem Zustand heissen sie Dauercysten oder encystirte Amöben. Die Gründe zu diesem Phänomen sind nieht immer klar; sie mögen sein Schutz gegen äussere Einflüsse, wie Austrocknung, faulige Verderbniss des Wassers, oder Nahrungsmangel, Ruhe zur Assimilation der Nahrung spielen dabei mit. Wie Celli und Fiocea bei ihren Culturen bemerkten, ist der Entwicklungseyelus der Amöbenspecies nicht immer von gleicher Dauer, er schwankt von 24-84 Stunden, bei Amoeba arborescens zieht er sieh über mehrere Tage hin. Im Stadium der Eneystirung besteht die Amöbe aus einem mehr oder weniger gekörnten Inhalt (maulbeerförmiges Aussehen bei Amoeba spinosa), aus einem mehr 
oder weniger deutlichen Kern und einer Hülle. Letztere kann einfach sein, meist ist sie doppelwandig. Die innere Hülle ist glatt rund, die äussere entweder glatt oder gerunzelt. - So ist bei Amoeba guttula, oblongata und spinosa die innere Contour rund, die andere gezackt. Bei Amoeba spinosa ist die innere Wand nicht ganz kreisrund, sondern mehr oder weniger rundlich oder eckig, so dass zuweilen Fünf- oder Seehsecke entstehen. Die Cystenformen sind bei den einzelnen Species ziemlich constant, so dass sie cin wichtiges differential-diagnostisches Merkmal abgeben. Auch bei den beschalten Süsswasserformen seheint die Eneystirung ganz allgemein zu sein. Dieselbe kann innerhalb der Schalen, als auch ausserhalb erfolgen. Gewöhnlich encystiren sie sich innerhalb der Schalen und unter deren Schutz. Zuweilen bildet sich eine solche nur an der ovalen Seite des Weichkörpers, z. B. Pseudochlamys patella. Doppelte Cystenhüllen scheinen bei den Euglyphinen allgemein zu sein.

Bringt man Cysten in einen hängenden Tropfen, so kann man nach 2-6 Stunden die Keimung derselben beobachten. Der körnige Inhalt beginnt sich allmälig zu bewegen und zwar derartig, dass er sich nach einer Seite zusammenzieht. Die Hülle klappt auf, der granulirte Inhalt tritt allmälig als junge Amöbe aus dem Spalt hervor. Einige Minuten hängt sie dann noch mit der Cyste zusammen, dann wird der Sprössling frei. Die Cyste rollt sich zusammen und verschwindet mit der Zeit.

Zur Biologie der Amöben, ihrem Verhalten gegen versehiedene Temperaturen, Medien, Gase und Chemikalien, Reizen etc. sei noch Folgendes registrirt:

Wenn man Amöben einer Wärmetemperatur von ca. $40^{\circ} \mathrm{C}$. aussetzt, gehen sie zu Grunde. Sie ziehen die Fortsätze ein und wandeln sich in eine kugelförmige, scharf und doppeltcontourirte Blase um, welche einen grossen trüben, im durchfallenden Licht bräunlich erscheinenden Klumpen birgt (Wärmetod). Bei einer Temperatur von einigen Graden niedriger ziehen die Amöben dic Pseudopodien ein, runden sich ab, die Körnehenströmung sistirt, es tritt ein Zustand der Ruhe ein, ohne dass der Tod erfolgt (Wärmestarre). Bei Aenderung der Temperatur kann sich die Bewegung wieder einstellen. Ebenso tritt ein Zustand der Ruhe ein bei Abkühlung (Kältestarre); durch Zunahme der Wärme tritt wieder Bewegung und Strömung des Protoplasmas ein. Niedrige Temperaturen sind den Amöben weniger schädlich als hohe. Bei sehr niedriger, anhaltender Temperatur erfolgt der wirkliche Kältetod; das Protoplasma gerinnt und trübt sich; unter Quellungserscheinungen beginnt dasselbe zu zerfallen. Celli 
und Fioecia haben bei ihren Culturversuchen das Verhalten der Amöben gegen bestimmte Temperaturgrade studirt; nach ihren Angaben konnten die amöboiden und encystirten Formen Temperaturen von $0-15^{0}$ während mehrerer Stunden und Tage aushalten, ohne abzusterben. $45^{\circ}$ C. tödtete sic in 5 Stunden, $50^{\circ}$ in einer Stunde $i_{m}$ amöboiden Stadium. Encystirt sind sie im Stande $55^{\circ}$ C. vier Tage lang zu ertragen, bei $60^{\circ}$ C. eine Stunde und sogar bei mehrstündiger Einwirkung von $67^{\circ} \mathrm{C}$. halten sie sieben 'l'age ans. Gegen Sonnenlicht sind sie widerstandsfähig, trocken und feucht, bis zu 11 Tagen bei einer mittleren Temperatur von $12-15^{\circ}$. Der mehr oder weniger schnellen Austrocknung widerstehen sie bei diffusem Licht oder in der Dunkelheit dauernd. Ohne Luftzutritt gedeihen sie nicht; versetzt man sie aber nach 4-6 IIonaten auf den gewöhnlichen Nährboden zuräck, so tritt wieder eine Vermehrung ein. Hält man die Luft 10 Nonate ab, so sterben sie allmälig.

Das allmälige Absterben der Amöben documentirt sich in folgender Weise. Die Beweglichkeit lässt 1sach, die Kugelgestalt tritt ein, die Scheidung zwischen Ecto- und Entoplasma verliert sich, der Kem wird deutlicher. Nach und nach zeigt sich Degeneration. sie werden homogen, fettähnlich glänzend und zerfallen körnig, öfters, nachdem sie sich vorher in einzelne runde Stücke getheilt haben.

Wasser hat je nach Beschaffenheit und Temperatur einen verschiedenen Einfluss auf die Amöben. Plötzliche Veränderungen wirken meist schädigend. IIeerwasseramöben gedeihen fort, wenn durch langsame Verdunstung das offenstehende Neerwasser einen Salzgehalt von 10 pCt. erlangt hat. Süsswasseramöben kann man allmälig an eine 4 proc. Kochsalzlösung gewöhnen, aber durch plötzlichen Zusat\% schon von einer 1 proc. Lösung findet eine Zusammenziehung in Kugeln und langsamer Zerfall in glänzende Tropfen statt. Die versehiedenen Species sind verschieden resistent gegen Veränderungen des Wassers. Die successive Anpassung spielt hierbei eine wichtige Rolle. Wie wir früher gesehen haben, können Amöben sogar im Thermalwasser und in heissen Quellen vegetiren. Faulende Medien wirken aber auf die Dauer schädigend ein. Nach Celli und Fioeca gehen sie darin im amöboiden Zustand nach 23 Tagen, encystirt nach 33 Tagen zu Grunde.

Gegen antiseptische Mittel (Kalkwasser, Salicylsäure, Gerbsäure, Phenol, Lysol, Sublimat ete.) sind sie empfindlicher als Bakterion im amöboiden und encystirten Stadium. Wasserstoffsulfid tödtet die amöboiden Formen binnen 8 Stunden, Hydrogenium arsenicosum binnen 3-10 Minuten, Kohlenoxyd bimen 5-30 Ninuten, Kohlensulfid binnen 
7 Stunden, Amylalkohol binnen 8 Stunden. Chininlösung 1: 1000, Chloralhydratlösung 0,5:100 etc. tödten nach meinen Beobachtungen Strohamöben in kurzer Frist. Anaesthetica, wie Chloroform, Aether etc., nur einige Zeit angewendet, wirken lähmend anf das Protoplasma, bei Sanerstoffzufuhr tritt jedoch wieder Erholung ein. Kohlensïure scheint den Amöben nicht zu schaden.

Es crïbrigt noeh, den Einfluss von Jicht, mechanischen, elektrischen und ehemischen Reizen in aller Kürze anzuführen, wie er von $\|$ ax Schulze, Kühne, Engelmann, Verworn etc. studirt worden ist. Die Einwirkung eines mässig starken Lichtstrahls bei Pelomyxa palustris bewirkt Einzichung der Pseudopodien zur Kugel. Erst nach einiger Zeit der Ruhe fängt die Amöbe im Schatten an, sich allmälig wieder zu bewegen. Ebenso wirken plötzliche heftige mechanische Erschütterungen und directe Reizungen der Fortsïtze mittclst einer Nadel. Nach Verworn sehnellen dabei manche Fäden so lieftig zurück, dass die Spitzen, welche an dem Objectträger kleben, abreissen. Bei schwacher Reizung dureh Inductionsschläge stockt die Körnchenbewegung und das Vorwärtskriechen der Amöben eine kurze Zeit lang, um nach einiger Frist wieder in der alten Weise fortgesetzt zu werden. Stärkere Schläge bewirken eine rasche Contraction der Fortsätze und Einziehen zur Kugclgestalt. Sehr starke Ströme zerstören den kuglis zusammengezogenen Körper durch Platzen. Längere Zeit fortgesetzte Inductionsströme haben eine stückweise Zerstörung und Verkleinerung zur Folge. Durch Anwendung des constanten Stromes entsteht beim Schliessen, z. B. bei Pelomyxa, an dem positiven Pol eine Erregung, die sich in Contraction der Fortsätze und länger einwirkend in einer Plasmazerstörung an der Eintrittsstelle des Stromes documentirt. Beim Oeffnen desselben sistirt die Einschmelzung an der Anode und es erfolgt dagegen eine bald vorübergehende Contraction an der der Kathode zugewendeten Körpcroberfläche. - Die dureh chemische Mittel hervorgerufenen Reizwirkungen auf Bewegung und Plasma der Amöben sind sehr verschicdener Natur, worauf wir hier nicht näher eingehen. Nur kurz erwähnt seien schliesslich die Bewegungen, welche durch die genannten Reize nach einer bestimmten Riehtung veranlasst werden. Man hat diese unter dem Namen Heliotropismus, Chemotropismus, Galvanotropismus etc. zusammengefasst und zwar je nach der Anzichung und Abstossung, sowie nach der Richtung zur Kathode oder Anode als negativen oder positiven Heliotropismus, Chemotropismus, Galvanotropismus etc. bezeichnet. Was z. B. den Galvanotropismus anbelangt, so erleiden die Amöben unmittelbar bei der Schliessung des 
constanten Stromes eine Sistirung der Körnchenströmung, damı treten plötzlich an dem der Kathode zugerichteten Ende hyaline Fortsätze auf, und indem in derselben Richtung die andere Leibessubstanz nachfliesst und immer wieder neue Scheinfüsse gebildet werden, kriechen die Amöben nach der Kathode zu. Bei Umkehr des Stromes tritt auch eine plötzliche ruekweise Umkehr der Strömung ein und die Amöben bewegen sich nach der entgegengesetzten Richtung.

\section{Capitel III.}

\section{Die Arten der Amöben.}

Bütschli veranschlagt die gesammten Arten der Rhizopoden auf ca. 650-700 an Zahl. Davon kommen ca. 600 auf die Meerwasserund ca. 100 auf die Süsswasserformen. Ihre Erforschung beginnt im 17. Jahrhundert mit dem Bekanntwerden des Mikroskops. Eine grosse Reihe von Arbeiten sind nothwendig gewesen, um die Natur der Rhizopoden klar darzulegen und ihre Stellung im zoologisehen System zu sichern. Im Grossen und Ganzen sind vier Hauptgruppen aufgestellt worden, die wir im ersten Capitel kurz angeführt und skizzirt haben.

Die Geschiehte der Amöbenforsehung geht mit dem Rhizopodenstudium Hand in Hand. Ihr Anfang ist in die Mitte des vorigen Jahrhunderts zu verlegen. 1755 beschrieb Rösel von Rosenhof die erste Amöbe unter dem Namen Proteus. Darauf entdeckten Gleichen und andere Forscher ähnliche Süsswasserformen. Der Name Amöbe rührt her von Bory de St. Vincent, der anfangs sehr weit gefasst war. Die verschiedenartigsten kleinen Thiere waren darunter einbegriffen. Bereits 1815 beschrieb Leelerc eine beschalte Süsswasseramöbe, eine Difflugie, die er in riehtiger Deutung auch als Verwandte des Rösel'schen Proteus bezeichnete. Sodann fand Ehrenberg noch eine andere beschalte Amöbe, die Arcella, auf deren Achnlichkeit mit Difflugia er hinwies. In seinem Werk „Die Infusionsthierchen als vollkommene Organismen", Leipzig 1838, unterschied er die beiden Familien Amoebaea und Areellina. Obwohl Ehrenberg sehr viel zur Kenntniss der Rhizopoden, besonders dureh Beobachtungen der fossilen Reste, beigetragen hat, hatte er doch von der inneren Structur dieser Organismen eine falsche Meinung. Bekanntlich 
vindieirte er ihnen die verschiedensten Organe, Ovarien, Darm ete. Erst durch Dujardin's zahlreiche und grundlegende Untersuchungen an lebenden recenten Formen brach sich allmälig die Ansicht durch, dass man es hier nicht mit complicirt zusammengesetzten, sondern einfacheh, einzelligen Organismen, deren Körpersubstanz aus Sarcode besteht, zu thun habe. Bei weiterem Studium dieser Lebewesen suchte man anch besondere Arten unter den Amöben festzustellen. Die ersten Kriterien zur Unterscheidung ron Arten bezogen sich auf Forthewegung, Form, Farbe und andere variable Punkte. Dujardin elassifieirte hauptsächlich nach der Grösse und Form der Pseudopodien, als dem Nächstliegenden, ohne diesen Eigenschaften den Werth wirklicher specifischer Unterseheidungsmerkmale zuzuerkennen. $\mathrm{Cla}$ parède und Lachmann hielten nicht viel von der Aufstellung gewisser Speeies der Amöben und verwiesen die Classification derselben auf eine spätere Zeit. In den folgenden Jahren wurden weitere Arten beschrieben, indem dieses oder jenes Merkmal in den Vordergrund gestellt. wurde. Line grosse Reihe von Autoren sind hier zu nennen, die sich "um die genauere Kenntniss der Amöbenformen viele Verdienste erworben haben. Abgesehen von den Forschern, welche die fossilen Arten zum Gegenstand ihrer Beobachtungen machten, führe ich an: Leidy, Maggi, Wallich, Joh. Müller, Schlumberger, Perty, Reuss, Lieberkühn, Auerbach, Leuckart, Greeff, Carter, Carpenter, Stein, Max Sehulze, Haeckel, Neresehkowsky, Archer, Frommentel, Entz, M. Braun, Cienkowsky, Hertwig, F. E. Sehulze, Lesser ete. Besonders hat Bütschli sich um diese Kleinlebewelt hervorragend verdient gemacht. Die feinere Structur, die Theilungs- und Fortpllanzungsvorgänge, die Vorgänge der Kerntheilung ete. wurden allmälig mehr in den Kreis der Betrachtung gezogen. Fine Zusammenstellung der einzelnen in der Literatur beschriebenen Species der Amöben versuchte Maggi, er kommt auf 44 Arten, Grassi, mit Hinzufügung neuer, auf ea. 50 Arten. Trotz emsigen Fleisses auf diesem Ciebiete hat man sich bislang über die Classificationsprincipien nicht einigen können. Man hat untersehieden in Bezug auf Kernlosigkeit und Kernbesitz: Nucleata und Innucleata, in Bezug auf die Anwesenheit oder $A$ bwesenheit einer entractilen Vacuole: Sphygmica und Asphyeta, in Bezug auf die Art der Pseudopodienbildung: Lobosa und Reticulosa, in Bezug auf die Anwesenheit oder Abwesenheit einer Schale: Nuda und Testacea etc. Auch feinere Structurverhältnisse, wie Vorhandensein oder Nichtvorhandensein von Ectoplasma, die Verschiedenartigkeit des Schalenmaterials etc. hat man als Hilfsmittel zur Trennung hervorgehoben. Als scharfe, durch- 
greifende Unterschiede sind die genannten Kriterien nicht immer stichhaltig geblieben. Wir unterscheiden mit Bütschli 2 Unterabtheilungen der Amöben, welehen sich das bisher Bekanntgewordene am besten einreihen läst, Amoeba nuda und Amoeba testacea.

\section{Nuda.}

Kernhaltige Organismen von versehiedener Gestalt mit stumplen und netzbildenden Pseudopodien, zuweilen ohne Fortsätze fliessend sich bewegend. Contractile Vacuolen sind meist vorhanden. Fortpflanzung dureh Zweitheilung und Sprossung. Wohnort: Süss- und Meerwasser.

Von Amöbenarten sind in der Literatur, wie erwähnt, eine grosse Reihe beschrieben worden, wie z. B.:

Amoeba proteus, Roesel von Rosenhof,

Trichamoeba, Frommentel,

Jithamoeba, Lankester,

Dinamoeba, Leidy,

Chaetoproteus, Stein,

Amoeba princeps, Ehrenberg, Auerbach.

Amoeba difluens, Ehrenberg,

Hyalodiscus, Hertwig und Lesser,

Amoeba guttula, Dujardin,

Amoeba vermicularis, Weisse,

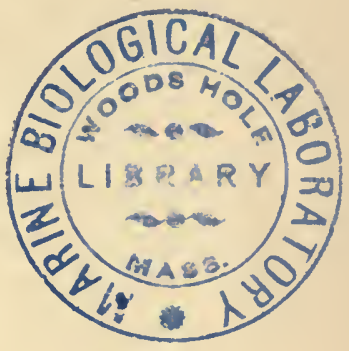

Amoeba oblonga, Lieberkühn (Maggi),

Amocba lobosa, Bütschli,

Amoeba reticulosa, Bütschli,

Amoeba Gleicheni, Dujardin,

Amoeba villosa, Wallich,

Amoeba radiosa, A uerbach (Perty),

Amoeba polypodia, F. E. Sehulze,

Dactylosphaera, Hertwig und Lesser,

Podostoma, Claparède und Lachmann,

Amoeba verrucosa, Dujardin,

Amoeba quadrilatera, Carter,

Amoeba brevipes, Greeff,

Amoeba oblonga, Schmarda,

Amoeba crystalligera, F. Schneider,

Mastigamoeba, F. E. Schulze,

Amoeba bilimbosa, Auerbach,

Amoeba bachiata, Dujardin,

Amoeba lacerata, Dujardin, 
Amocba sphaerococea, Haeckel,

Amoeba monociliata, Carter,

Amoeba terrieola, Greeff,

Amoeba alveolata, Mereschkowsky,

Amoeba jelaginia, Mereschkowsky,

Amoeba Limax, Dujardin,

Amoeba Blattae, Dujardin,

Amoeba succinea, I. Pfeiffer,

Amoeba coli, Loesch,

Amoeba intestini vulgaris, Quinke und Roos,

Amoeba coli mitis, Quinke und Roos,

Amoeba muris, Grassi,

Amoeba coli, Schardinger,

Amoeba gingivalis, Gros,

Amoeba bucealis, Sterniberg,

Amoeba dentalis, Grassi,

Amoeba urogenitalis, Baelz,

Leydenia gemmipara Schaudinn ete.

Wir sehen, die soeben aufgezählten Species sind nach ganz versehiedenen Criterien benannt, nach Wohnort, Fundort im mens'hlichen Körper, der allgemeinen Gestalt, der Art der Fortsätze, dem Fortpflanzungsmodus, dem Namen des Entdeckers ete. Darunter sind vicle Species identisch, Varietäten oder Synonyma, vielleieht auch nur Entwiekelungsstadien anderer Protozoen. Kaum in einer Abtheilung der Thierwelt herrseht eine so grosse Verwirrung in der Artbegrenzung. Die

\begin{tabular}{|c|c|c|c|c|c|}
\hline \multirow{2}{*}{ Species } & \multirow{2}{*}{ Varietät } & \multirow{2}{*}{ Wohnort } & \multicolumn{3}{|r|}{ Im Amöben- } \\
\hline & & & Form & Bewegung & Grösse \\
\hline A. Iobosa & guttula. & $\begin{array}{l}\text { Boden, Luft, Was- } \\
\text { ser, Darm. }\end{array}$ & $\begin{array}{l}\text { Buchtig ge- } \\
\text { streckt. }\end{array}$ & $\begin{array}{l}\text { Lebhaft, mit Aus- } \\
\text { streckung von ge- } \\
\text { lappten Pseudopo- } \\
\text { dien Fortbewegung. }\end{array}$ & $\begin{array}{c}\text { Längsdurch. } \\
\text { messer } 2-4, \\
\text { Querdurchm } \\
1-2 \mu .\end{array}$ \\
\hline A. labosa & oblonga. & $\begin{array}{l}\text { Boden, Wasser, } \\
\text { Darm. }\end{array}$ & Idem. & Idem. & $\begin{array}{l}\text { Id. } 4-8 \mu . \\
\text { ld. } 2-4 \mu \text {. }\end{array}$ \\
\hline A. lobosa & undulans. & Boden, Wasser. & $\begin{array}{l}\text { Breit u. buch- } \\
\text { tig. }\end{array}$ & $\begin{array}{l}\text { Lebhaft, mit Wellen- } \\
\text { bewegungen d. Con- } \\
\text { tour und Fortbewe- } \\
\text { gung. }\end{array}$ & $6-12 \mu$ \\
\hline A. lobosa & $\begin{array}{c}\text { coli, s.spät. } \\
\text { ausführl. }\end{array}$ & - & - & - & - \\
\hline
\end{tabular}


kritische Würdigung allein kann hier nicht Ordnung schaffen; es ist. klar, dass bei weiterem Studium eine Reduction der Arten eintreten muss mit bestimmt fixirten Ilerkmalen; aber diese genauere Auseinanderhaltung ist nur möglich durch den von einzelnen Forschern bercits betretenen Weg der Züchtung. Diese gewährt ein Gesammtbild der constanten biologischen Eigensehaften einer Species und ermöglicht cine rationelle systematische Classification. Den Anfang dazu haben gemacht Celli, Fiocea, Beyerinck, Schardinger, Maggi, Monti, Casagrandi, Barbagallo, Froseh ete. Vor allem sind die beiden italienischen Forscher auf diesem Gebiete thätig gewesen und haben eine Reihe von einzelnen Aınöbenspecies auf künstlichem Nährboden gezïchtet. Ein Ensemble von Unterscheidungsmerkmalen dient ihnen bei der Benennung als Richtschnur. Diese sind: 1. Wohnort, 2. Zeichen des amöboiden Stadiums: Form, Bewegung. Grösse, Structur; 3. Fortpllanzungsmodus; 4. Merkmale des Ruhezustandes; 5. Merkmale des Cysten-oder Dauerzustandes; 6. Entwickelungscyklus. Ganz recht betonen diese Autoren, dass Form, Grösse, Struetur wegen der Aehnlichkeit zur Unterscheidung nicht genügen; es gehören dazu auch die anderen Merkmale. Celli und Fiocea heben besonders die Constanz der Cysten der cinzehnen Species als maassgebend hervor; sie führen an, dass ein geübtes Auge dic von ihnen cultivirten Amöbenarten mit Ausnahme von Amoeba vermicularis und A. diaphana mit Sicherheit nach dem eigenartigen Cystenzustand erkennen kann. Eine gute Uebersicht der culturell charakterisirten Species geben sic in folgender Tabelle:

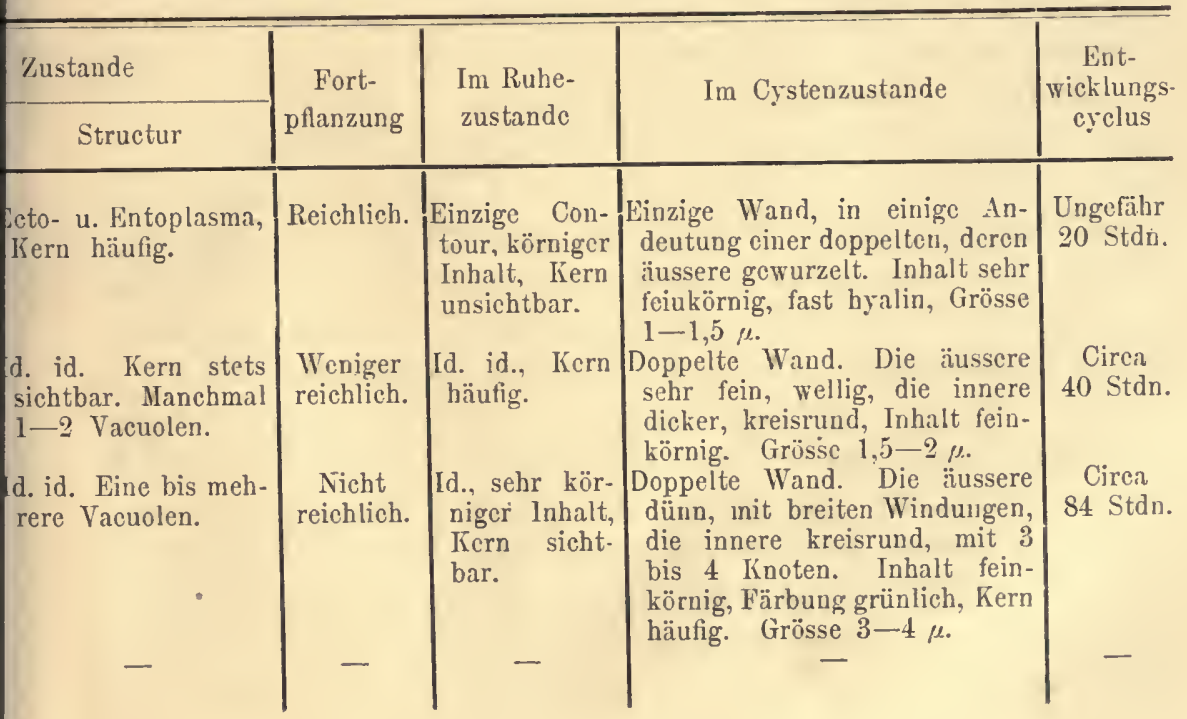




\begin{tabular}{|c|c|c|c|c|c|}
\hline \multirow{2}{*}{ Species } & \multirow{2}{*}{ Varietät } & \multirow{2}{*}{ Wohnort } & \multicolumn{3}{|c|}{ Im Amöben- } \\
\hline & & & Form & Bewegung & Grösse \\
\hline A. spinosa & - & $\begin{array}{l}\text { Boden, Sumpf, } \\
\text { Luft, Wasser, ge- } \\
\text { sunder und kran- } \\
\text { ker Menschen- } \\
\text { darm, Scheide, } \\
\text { Thierdarm. }\end{array}$ & $\begin{array}{l}\text { Rundlich, zer- } \\
\text { klüftet. }\end{array}$ & $\begin{array}{l}\text { Träge, mit Ausstreck. } \\
\text { von spitzen Pseudo- } \\
\text { podien, wenig oder } \\
\text { keine Fortbewcgung. }\end{array}$ & $6-10$ \\
\hline $\begin{array}{l}\text { A. dia- } \\
\text { phana }\end{array}$ & - & Boden, Darm. & Unregelmässig & $\begin{array}{l}\text { Sehr lebhaft, mit Aus- } \\
\text { strecken von Pseudo- } \\
\text { podicn oder von } \\
\text { Spitzen oder Wellen- } \\
\text { bewegung. Wenig } \\
\text { oder keine Forthe- } \\
\text { wegung. }\end{array}$ & $0,5-2 \mu$. \\
\hline $\begin{array}{l}\text { A. vermi- } \\
\text { cularis }\end{array}$ & - & $\begin{array}{l}\text { Boden, Wasser, } \\
\text { Sehlamm, Schei- } \\
\text { denseerct, Dy- } \\
\text { sent. Darm. }\end{array}$ & $\begin{array}{l}\text { Gestreckt wie } \\
\text { ein Würm- } \\
\text { chen. }\end{array}$ & $\begin{array}{l}\text { Träge, hakenförmig. } \\
\text { Langsame Fortbe- } \\
\text { wegung. }\end{array}$ & $\begin{array}{c}3-6 \mu . \\
1 \mu .\end{array}$ \\
\hline $\begin{array}{l}\text { A. reti- } \\
\text { cularis }\end{array}$ & - & $\begin{array}{l}\text { Boden, Thermal- } \\
\text { schlamm, Sumpf, } \\
\text { dysent. Darm. }\end{array}$ & $\begin{array}{l}\text { Unregelmäss., } \\
\text { mit zu einem } \\
\text { Netz vereinig- } \\
\text { ten Fäden. }\end{array}$ & $\begin{array}{l}\text { Sehr träge, kaum eine } \\
\text { Veränderung der } \\
\text { Contour. Wenigoder } \\
\text { keine Fortbewegung. }\end{array}$ & $\begin{array}{l}2-4 \mu, \text { mit } \\
\text { den H'äden } \\
S-14 \mu .\end{array}$ \\
\hline $\begin{array}{l}\text { A. arbo- } \\
\text { rescens }\end{array}$ & - & Sumpfschlamm. & $\begin{array}{l}\text { Ganz aus ver- } \\
\text { zweigten } \\
\text { Pseudopodien } \\
\text { bestehend. }\end{array}$ & $\begin{array}{l}\text { Ziemlich lebbaft, mit } \\
\text { Ausstrecken ron } \\
\text { stets verzweigten } \\
\text { Pseudopodien. Lang- } \\
\text { same Fortbewegung. }\end{array}$ & $5-12 \mu$. \\
\hline
\end{tabular}

Sodann wurden von Beyerinck zwei Arten bekannt gemacht, welche er auf künstlichem Nährboden gezüchtet hat, seine Amocba nitrophila und Amoeba zymophila.

Amocba nitrophila: Grösse $15-20 \mu$. Protoplasma sehr hyalin, Zellkern deutlich, meist 2 Vacuolen, wovon die eine langsam pulsirt, während die andere ruht. Mit der pulsirenden Vacuole stehen oft drei Nebenvacuolen in Verbindung. Bildet Sporen mit doppelter Wandung, aus denen junge Amoeben auskeimen, die sich theilen. In der Gartenerde von Delft sehr verbreitet. In jedem Dekagramm Erde fast ausnahmslos auf den nitrificirenden Agarplatten gefunden.

A moeba zymophila. Grösse 10-12 $\mu$ mit einem Zellkern. Sporen- und Cystenbildung nicht beobachtet. Vermehrung nur dureh Theilung, sehr sehnell vor sich gehend. Pulsirende und Nebenvacuolen fehlend. Gezüchtet von Trauben aus einem Garten in Gelderland, welche durch Wespen angenagt und in spontane Gährung übergegangen waren, auf einem Nïhrboden von Malzextractgelatine, welcher Essigbacterien enthielt. 


\begin{tabular}{|c|c|c|c|c|}
\hline Zustande & \multirow{2}{*}{$\begin{array}{l}\text { Fort- } \\
\text { pflanzung }\end{array}$} & \multirow{2}{*}{$\begin{array}{l}\text { Im Ruhe- } \\
\text { zustande }\end{array}$} & \multirow{2}{*}{ Im Cystenzustande } & \multirow{2}{*}{$\begin{array}{l}\text { Ent- } \\
\text { wicklungs } \\
\text { cyclus }\end{array}$} \\
\hline Structur & & & & \\
\hline $\begin{array}{l}\text { ärliches oder un- } \\
\text { ichtbares Ectoplas- } \\
\text { na, Kern nicht im- } \\
\text { ner sichtbar. } 1 \text { bis } \\
\text { t Vacuolen. }\end{array}$ & $\begin{array}{l}\text { Ziemlich } \\
\text { reichlich. }\end{array}$ & $\begin{array}{l}\text { Oberfläche oft } \\
\text { warzig, Inhalt } \\
\text { körnig, Kern } \\
\text { manchmal } \\
\text { sichtbar. }\end{array}$ & $\begin{array}{l}\text { Wie in A. oblonga, aber mit } \\
\text { innerer Wand, eckig oder rund- } \\
\text { lich. }\end{array}$ & $\begin{array}{c}\text { Circa } \\
60 \text { Stdn. }\end{array}$ \\
\hline $\begin{array}{l}\text { hr spärliches und } \\
\text { iicht immer sicht- } \\
\text { oares Protoplasma, } \\
\text { iern meist unsicht- }\end{array}$ & $\begin{array}{l}\text { Schr reich- } \\
\text { lich. }\end{array}$ & $\begin{array}{l}\text { Einzige Con- } \\
\text { tour, körniger } \\
\text { Inhalt. }\end{array}$ & $\begin{array}{l}\text { Einzige Wand, punktirter In- } \\
\text { halt. Grösse } 0,6--2 \mu \text {. }\end{array}$ & $\begin{array}{c}\text { Circa } \\
30 \text { Stdn. }\end{array}$ \\
\hline $\begin{array}{l}\text { inzige hyaline oder } \\
\text { ehrfeinkörnige Sub- } \\
\text { itanz, Kern häufig. }\end{array}$ & $\begin{array}{l}\text { Ziemlich } \\
\text { reichlich. }\end{array}$ & $\begin{array}{r}\text { Id. id., Grösse } \\
\text { einheitlicher. }\end{array}$ & $\begin{array}{l}\text { Id. id. Grössc einheitlicher, von } \\
0,5-1 \mu .\end{array}$ & $\begin{array}{c}\text { Cirea } \\
70 \text { Strn. }\end{array}$ \\
\hline $\begin{array}{l}\text { inzige hyaline Sub- } \\
\text { tanz, ohne sicht- } \\
\text { oaren Kern. }\end{array}$ & $\begin{array}{l}\text { Ausser- } \\
\text { ordentlich } \\
\text { reichlich. }\end{array}$ & $\begin{array}{l}\text { Id. id., Grösse } \\
\text { sehr wech- } \\
\text { selnd. }\end{array}$ & $\begin{array}{l}\text { Einzige Wand, hyaliner oder } \\
\text { schr fein getiupfelter Inhalt. } \\
\text { Grösse sehr wechselnd, } 0,2 \text { bis } \\
2\end{array}$ & $\begin{array}{c}\text { Circa } \\
20 \text { Stdn. }\end{array}$ \\
\hline $\begin{array}{l}\text { I. id., Kern manch- } \\
\text { nal sichtbar. }\end{array}$ & $\begin{array}{l}\text { Sehr ge- } \\
\text { ring. }\end{array}$ & $\begin{array}{l}\text { Id., körniger, } \\
\text { sehr licht- } \\
\text { brechender } \\
\text { Inhalt, Kern } \\
\text { sichtbar. }\end{array}$ & $\begin{array}{l}\text { Doppelte Wand, äussere dicker, } \\
\text { leicht gewölbt, innere kreis- } \\
\text { rund. Der Inhalt besteht aus } \\
1 \text { bis } 2 \text { grossen Körnchen und } \\
\text { aus einer feinkörnigen und } \\
\text { hyalinen Masse. Grösse ron } \\
1,5-2 \mu .\end{array}$ & $\begin{array}{l}\text { Einige } \\
\text { Tage. }\end{array}$ \\
\hline
\end{tabular}

Als eine gezüchtete Species ist ferner anzuführen die Amoeba coli Schardinger. Grösse durchschnittlich 15-20 $\mu$. Lebhaft beweglich. Pulsirende Vacuolen nicht beobachtet. Cystenbildung. Cysten rund oder polygonal mit einem farblosen, scharf abgegrenzten Saum und einem gekörnten Inhalt von bräunlicher Farbe; darin 1-2 Kerne. Wachsthum bei Bruttemperatur auf einem Nährboden von Heuinfusagar. Gezüchtet aus dem Darm eines an fieberhafter Diarrhoe leidenden Mannes.

Weiter hat Frosch eine Amöbenart cultivirt, welche der Gartenerde entstammt, im Allgemeinen ähnlich der Amoeba nitrophila Beyerinck, jedoch in einzclnen Punkten von ihr abweichend. Charakteristische Nerkmale: lappige Fortsätze, sich stetig verändernd, mit Kern und contractiler Vacuole. Vermehrung durch Theilung, unter gewissen Umständen auch durch Sprossung, bildet Cysten von durchschnittlich $12 \mu$ Grösse, mit deutlich doppeltcontourirter, stark lichtbrechender Schale, in deren Innern stets ein kernähnliches Gebilde liegt, umgeben von cincm Kranz radiär gestellter Stäbchen. Die 
Schale hat an drei Stellen, welche gdeichweit von einander entfernt sind, kegelstumpfähnliche Verdünnungen von der inneren Wand ausgehend, welehe mit der schmalen Basis an der äusseren Wand endigen, ohne jedoch dieselbe zu durchbreehen. Gezüchtet auf einem Agarnährboden von bestimmter Zusammensetzung (cf. Cap. Züchtung der Amöben). Ferner ist anzuführen die Amoeba albuminis, welche von Balsamo-Crivello und Maggi sowie Monti auf Eiereiweiss cultivirt wurde, und melirere Amöben, welche von Casagrandi und Barbagallo gezüchtet wurden, wie Amoeba viridis, foliata, nudosa, diffluens, gracilis etc.

Ausser den aufgezählten cultivirten Amöben seien hier noch folgende unbeschalte amöbenartige Rhizopoden aus der literatur aufgeführt, Bütschli folgend. Die Moneren Häckel's, Protamoeba, Myxodictyon, Protomyxa ele., deren Zugehörigkeit zu den Rhizopoden fraglich ist, schliessen wir hier aus.

Pelomyxa palustris Greeff, amöbenartig, von beträchtlicher Grösse (bis $2 \mathrm{~mm}$ ) Durchmesser, mit bruchsackartigen, stumpfen Pseudopodien, mit zahlreichen Kernen und sogenannten Glanzkörpern, gewölnnlich auch mit kleinen, stäbchenartigen Körperchen. Süsswasser.

Amphizonella Greeff, amöbenartig, mit ziemlich dicker gallertiger Ḧ̈lle, die von kurzen, hyalinen, fingerartigen Pseudopodien durchbohrt werden. Wohnort: feuchte Erde, Süsswasser.

Placopus F. E. Schulze. Synon. Hyalodiscus Mereschkowsky. Mit Kern und contractiler Vacuole. Pseudopodien abweichend, schwimmhautartige Plattenfortsätze. Es treten mehrere unter verschiedenen Winkeln zueinander gestellte und miteinander versehmelzende Lamellen auf der Oberfläche des Thieres hervor; dieselben sehliessen trichterartige oder kappenförmige Hohlräume mit weiter nach aussen gerichteter Mündung ein. Zuweilen jedoch auch in hyalodiseusartigen Zustand übergehend. Encystirung ziemlich wahrscheinlich, die dünne Cystenwand besitzt eine regulär kugelige Bildung und liegt dem Weichkörper dicht anf. Wohnort: Süsswasser.

Leydenia gemmipara Schaudinn, amöbenähnlicher Rhizopode. Gewöhnlich 1 Kern und 1 pulsirende Vacuole. Pseudopodienbildung ähnlich wie bei Placopus. Fortpflanzung durch Theilung und Knospung. Näheres später im Capitel Parasitäre Amöben.

\section{Testacea.}

Auch diese bilden keine fest abgeschlossene Gruppe. Die Ausbildung der Schalen ist manchmal eine sehr geringe. Wir rechnen hierher mit Bütschli auch die mit weniger gut ausgebildeter Hülle 
versehenen Formen, die ron R. Hertwig als Lepamocba unter die Familie Amoebina gezählt werden. Charactermerkmale: Schalenwandung mehr oder weniger solid, nicht von feinen Poren durehbohrt, dagegen mit einer Mündung rersehen. Es gehören hierher die einaxigen, einschaligen, einwandigen Formen. Die Abgrenzung gegen die Foraminifera ist schwer. Die Amplistomata bei Seite lassend, führen wir hier an dic 3 Familien Arcellina, Euglyphina und Gromiina.

1. Familie. Arcellina: meist ein Kern und contratile Vacuole. Schale einachsig, kappenförmig bis langgestreckt. Lappige Pseudopodien.

Cochliopodium, Hertwig und Lesser, Schale biegsam, dünn und von kappenartiger Gestalt, dem Weichkörper dicht anliegend. Weite IIündung. Jobose Fortsätze, bündelartig hervortretend. Cochliopodium bilimbosum Auerbach. Süsswasser.

Arcella vulgaris, Ehrenberg und von zahlreichen anderen Forschern beschrieben. Schale von feiner Gitterstructur, uhrglasförmig, mit convexer Oberseite und flacher Oralseite, in letzterer Mündung in der Mitte kreisrund. Farbe braun. Weichkörper die Schale nicht ganz ausfüllend. In der Regel mit mehreren Kernén und Vacuolen. Wohnort: Süsswasser, feuchter Sand und Moos. Mehrere Arten. Aehnlich Pyxidicula Ehrenberg und Pscudochlamys Claparède und Lachmann, nach Bütschli vielleicht Jugendzustände der Arcella.

Hyalosphenia Stein. Gestalt oval oder birnenförmig, mit verlängerter Hauptachse. Etwas comprimirt. Schalc chitinös, strueturlos. Mündung einfach. Thierkörper die Schale nicht völlig ausfüllend. Süsswasser. Mehrere Arten.

Quadrula F. E. Schulze, Gestalt oval, birnenförmig, weniger comprimirt als Hyalosphenia, Schale meist aus quadratischen, glashellen Plättchen aufgebaut, am Hinterende der Schale zuweilen bestachelt. Verschiedene Arten, z. B. Quadrula symmetrica Wallich.

Difflugia proteiformis, Ehrenberg. Von vielen Forsehern beschrieben. Gestalt variabel, einachsig, kugelig, bis langgestreckt. Hinterende zuweilen in eine Spitze ausgezogen oder mit mehreren hornartigen Fortsätzen versehen. Häufig stark comprimirt. Mündungsrand nicht selten nach innen oder aussen umgeschlagen. Weichkörper die Schale in der Regel nicht ganz ausfüllend. Fortsätze lappig, selten etwas zerschlitzt. Kerne und Vacuolen mehr oder weniger zahlreich. Schalc mit Fremdkörpern incrustirt, die durch chitinöses oder zum Theil protoplasmatisches Bindemittel verkittet werden (vor- 
zugsweise Sandkörnchen, Diatomeenschalen, seltener runde bis ovale Scheibchen sowie cylindrische Stäbchen von zweifelhafter Herkunft). Circa 1 Dutzend Arten sind beschrieben, z. B. Difflugia oblonga Stein, - triangulata Lang, - carinata Archer, - globulosa Dujardin, - marsupiformis Wallich, - aculeata (Echinopyxis Claparède nnd Lachmann, Centropyxis Stein) Ehrenberg, - acropoda Hertwig und Lesser, - corona Wallich, -- pyriformis Perty, -- acuminata Ehrenberg, - lageniformis Wallich (urceclata Carter), - Lecquereusia spinalis Leclere, - bipes Carter, - Pseudodifflugia (?) Helix Entz, Pseudodifflugia amphitrematoides Areher.

Petalopus, Claparède und Lach mann. Schale zweifelhaft, oval. Pseudopodien mit vorn abgestutztem Vorderende ausgehend, etwas verästelt und an den Enden plattenartig verbreitert. Ob Nucleus und contractile Vacuole? Süsswasser.

2. Familie. Euglyphina: Schale chitinös oder kieselig, aus hexagonalen oder rundlichen Plättchen bestehend, einachsig bis bilateral. Fadenartige Fortsätze, wenig anastomosirend. Mit Kern und contractiler Vacuole.

Euglypha. Dujardin und andere Untersucher, Carter, Hert-. wig, Lesser, F. E. Schulze etc. haben sie zum Gegenstand ihrer Forschungen gemacht. Schale aus kieseligen, kreisförmigen bis hexagonalen Plättchen bestehend, in schiefen Reihen angeordnet, einachsig, ellipsoidisch bis beutel- und birnenförmig. Weite Mündung mit zackigem Rand. Am hintern Ende lıäufig Stacheln, auch zuweilen an der ganzen Oberfläche kurze Stacheln. Fortsätze nicht anastomosirend. Süsswasser. Verschiedene Arten, z. B. Euglypha alveolata Dujardin, - globosa Hertwig und Lesser, - compressa Carter etc.

Trinema Dujardin (Carter, Hertwig, Lesser; F. E. Schulze etc.), ähnlich Euglypha in der Schalenstructur und Gestalt. Mündung auf etwas abgeplattete Unterfläche gerückt und somit Schale bilateral. Süsswasser.

Cyphoderia margaritacea, Schlumberger (Hertwig, Lesser, F. E. Schulze etc.). Schale aus chitinösen Plättchen gebildet, jedoch kleiner als bei Euglypha und Trinema. Gestalt länglich beutelförmig, mit halsartig gerader oder nach der Seite gewendeter Mündung. Süsswasser und Ostsce.

3. Familie. Gromiina, Bütschli: Schale chitinös, fast immer ganz structurlos. Gestalt einachsig, oder etwas bilateral, oval. Mlündung verengt. Fortsätze dünn, fadenförmig, spitzig, reticulös. Mit oder ohne Vacuole und Kern.

Lieberkühnia, Claparède und Lachmann. Syn. Gromia 
Cienkowsky. Gestalt eiförmig, Schale dünn, dicht anliegend. Mündung hinter dem etwas zugespitzten Vorderende. Fortsätze von einem Pseudopodienstiel, aus der Mündung hervortretend, sehr reiche Netzbildung. Olme contractile Vacuole und Kern. Süsswasser.

Microgromia socialis, R. IIertwig. Schale beutelförmig, klein, etwas bilateral. Mündung halsartig ausgezogen. Weichkörper die Schale nur zum Theil ausfüllend. Fortsätze von einem ovalen Pseudopodienstiel entspringend. 1 Kern und 1 contractile Vacuole. Häufig coloniebildend. Süsswasser.

Platoum, F. E. Schulze, ähnlich der vorigen. Mündung etwas spitziger ausgezogen. Schale biegsam, den Weichkörper nicht völlig ausfüllend. Häufig coloniebildend. Wohnort: Süsswasser, feuchte Erde und faulende Stoffe. Mehrere Arten, z. B. - stercoreum Cienkowsky.

Plectophrys, Entz, nur durch eine eigenthümliche faserige Schalenstructur von der vorigen abweichend. Wohnort: Salzteich bei Klausenburg (Ungarn).

Lecythium, Hertwig und Lesser. Schalengestalt ähnlich Microgromia, der Weichkörper dicht anliegend. Mit Kern. Gewöhnlich ohne contractile Vacuole. Zuweilen Colonien bildend. Süsswasser.

Gromia, Dujardin und von anderen Forschern beschrieben. Gestalt oviform oder sphärisch, Schale chitinös, dicht anliegend, biegsam. Wanddicke variabel. Weite Mündung. Fortsätze treten etwas nach aussen und überziehen die Oberfläche des Gehäuses dünn. Von diesem Protoplasma gehen feinste Fädchen nach allen Richtungen, sehr lang sich gabelnd und netzförmig sich verbindend mit benachbarten Fortsätzen. Kern ein- oder mehrfach. Meist ohne contractile Vacuole. Im süssen und Meerwasser. Mehrere Arten, z. B. - oviformis.

Diaphoropodon, Schale einachsig, oviform, aufgebaut aus losen vereinigten Fremdkörpern (besonders Diatomeen). Pseudopodien zweierlei Art; entweder zahlreiche, sehr lange, hyaline, zuweilen tannenbaumartig verästelt, aus der Mündung hervortretende oder haarförmige, nicht retractile, allseitig zwischen den Schalenpartikelchen hervorspringende, deren Pseudopodiennatur noch zweifelhaft ist. Mit contractiler Vacuole. Süsswasser. 
Capitel IV.

\section{Die parasitiiren Amöben.}

Unter den Protozoen befinden sich eine grosse Zahl parasitïrer Formen, welche für Thier und Menschen gesundheitsschädlich sind. Die Sporozoen besonders sind sämmtlich Parasiten und gefährliche Gäste. Die übrigen 3 Classen der Protozoen weisen im Allgemeinen nicht so pathogene Formen auf, sie sind nur theilweis parasitär. Parasitische Flagellaten beim Menschen kennen wir mehrere, z. B. Plagiomonas urinaria, Trichomonas vaginalis, Trichomonas hominis, Cercomonas intestinalis Lambl (Megastoma entericum Grassi). Thre pathogene Bedeutung ist nicht ïberall festgestellt. Von den Infusorien (Ciliaten) sind parasitische Formen aus den Ordnungen Heterotricha und Peritricha bekannt, wie Balantidium coli beim Nenschen und Schwein; auch deren Pathogenität ist nicht zweifellos. Den Vorticellen ist wohl ein schädlicher Einfluss abzusprechen.

Die Rhizopoden scheinen im Allgemeinen, soweit bis jetzt bekannt, selten eine parasitische Lebensweise zu führen. Was in dieser Beziehung von ihnen bekannt ist, bezieht sich auf Amöben, welche als Schmarotzer bei Thieren und Menschen gefunden sind. Nur unter den nackten Formen scheinen Parasiten vorzukommen. Von den beschalten Amöben ist Sicheres nicht beobachtet.

E. Buck theilt mit, dass Lecythium hyalinum sowohl in verschiedenen Räderthieren, Cyclopslarven und Infusorien, als auch in den Zellen von Süsswasserpflanzen parasitisch vorkomme. Durch Eindringen von Sporenkeimen und Entwicklung dieser Amöbenart sollen sic tödtlich auf dieselben wirken. Lambl will im Darmschleim cines Kindes Arcellen und Difflugien angetroffen haben, was wohl auf Täuschung zurückzuführen ist.

Die Literatur über parasitäre nackte Amöben besagt Folgendes:

1. Amöben in der Mundhöhle des Menschen. Es werden genannt: Amoeba gingivalis Gros, Amoeba buccalis Sternberg und Amoeba dentalis Grassi. Die beiden ersterwähnten sind im Weinstein der Zühne entdeckt worden. Thre pathologische Bedeutung ist nicht bewiesen. Ebenso ist zweifelhaft, ob es selbstständige Species oder nur Entwicklungsstadien anderer Organismen sind. Bei der Amoeba dentalis lässt Grassi selbst eine Verwechslung mit Speichelkörperchen zu. Celli und Fiocea haben in der Mundhöhle des Menschen 
niemals Amöben constatiren können. Dasselbe negative Resultat muss ich bestätigen, obwohl ich den Inhalt derselben anlässlich verschiedener Krankheiten mehrmals daraufhin untersucht habe. Dagegen bin ich mehrmals Amöben mit spitzen Fortsätzen in der Maulhöhle von aphthenseuchekranken Rindern begegnet, die jedoch nur als gelegentliche Mitbewohner, aus dem Trinkwasser herrührend, aufzufassen sind.

2. In dem Nasenschleim von Nenschen haben sich bisher nach meinen, sowie Celli's und Fiocea's Beobachtungen Amöben nicht gezeigt. Untersuchungen bei Thieren fehlen.

3. Unter den Parasiten der Ohren des Mensehen werden Amöben nicht erwähnt.

4. Der Augenschleim des Menschen wies keine Amöben auf.

5. Ebenso vermisst man sie bisher in dem Auswurf der Luftwege.

6. Im Mageninhalt des Menschen sind die beiden genannten italienischen Forscher auf Amöben gestossen und zwar auf Amoeba spinosa. Im Magen frisch geschlachteter Rinder fand ich mehrmals Amoeba oblonga neben verschiedenen Infusorien, die ohne Zweifel dureh Saufen von schlechtem Wasser hineingelangt waren.

†. Häufiger enthält der Darm des Nenschen Amöben. Von Celli und Fiocea wurden hier constatirt Amoeba guttula, oblonga, spinosa, diaphana; vermicularis, reticularis. Quincke und Rons entdeckten im Darm Amoeba intestini rulgaris und Amoeba coli mitis. Die Amoeba coli Loesch, welche von den versehiedensten Forschern bestätigt wurde, verdient wegen des ausserordentlichen Interesses, das sie in ihrer Bezichung zur Dysenterie hervorgerufen hat, ein eigenes ausführliches Capitel. Nicht nur im menschlichen, auch im Thierdarm sind verschiedentlich Amöben bemerkt worden, so von Celli und Fiocea z. B. bei Fröschen, was auch Lieberkühn's Untersuchungen bestätigen. Sie charakterisirten dieselke als Amoeba spinosa, die ich ebenfalls mehrfach im Darm von Rana esculenta antraf. Sodann fand man sie bei Mäusen (Amoeba muris, Grassi), Hühnern, Lämmern, Meersehweinchen, Katzen, Kaninchen (Waldenberg) etc.; ich beobachtete Amoeba spinosa auch im Darm von Schweinen und Ratten. L. Pfeiffer notirt als parasitäre Amöbe aus dem Darm von Blatta orientalis Amoeba blattae Bütsehli. Dieselbe ist gross, mehrkernig, vaenolenhaltig, hat lappige Pseudopodien, Cystenbildung. Bewegung träge. Vermehrung dureh directe Theilung. In dem Darm von Limax kommt vor Amoeba Limax. Diese ist langgestreckt, keulenförmig und streckt Fortsätze gewöhnlich nur an den Längspolen aus. Der die Richtung angebende Pol ist immer der breitere, weniger 
gekörnte. Bewegung meist gradlinig. In der Ruhe sich kuglig contrahirend. L. Pfeiffer entdeckte im Darm von Suecinea eine Amöbe, die er $\Lambda$ moeba succineae benannte. Sie ist einkernig, hat spitze Fortsätze, so dass der Rand zackig aussieht. Langsame Bewegung.

8. Amöben im Urogenitalapparat des Menschen; A inoeba urogenitalis Bael\%. In dem blutigen Urin einel 23 jährigen tuberculösen Patientin bemerkte Bael\% sich sehr lebhaft bewegende, der Amoeba coli gleichende Amöben, welche in der Ruhephase $0,05 \mathrm{~mm}$ gross waren, später auch in der Vagina, wesshalb er annimmt, dass sie aus der Vagina in die Blase gewandert seien. Ferner entdeckte 1889 Jürgens in kleinen Schleimhautcysten einer männlichen Harnblase Amöben. Drittens beobachtete 1893 Kartulis im blutigen Harn eines an einem Blasentumor leidenden Patienten träge und-kurze Pseudopodien ausstossende Amöben von 0,012-0,020 mu Grösse, deren Kerne und Vacuolen bei Methylenblaufärbung deutlich zu Tage traten. Ausserdem berichtet noch Posner 1893 von Amöben im Harn. Im blutigen, eiweisshaltigen, rothe und weisse Blutkörperchen und vereinzelte Nierenepithelien mit Cylind»rn enthaltenden Urin eines im Juli 1892 an Schüttelfrost erkrankten 37 jährigen Mannes zeigten sich amöboide Gebilde (0,050 mm lang, 0,028 mm breit) mit mehrfachen Kernen, Vacuolen, welche neben anderen fremden Einschlüssen rothe Blutkörperchen enthielten und langsam ihre Form veränderten. Nach einigen Tagen war der Urin blut- und amöbenfrei. Diese Attaque wiederholte sich später noch in unregelmässigen Pausen mehrere Male. Posner führt in diesem Falle die Erkrankung auf Amöben zurück und glaubt, dass dieselben von der Blase aus in das Nierenbecken gelangt sind, sich dort in einer Cyste eingenistet und von hier aus die mehrfachen Rückfälle hervorgerufen haben. Ob in den angeführten Beobachtungen den Amöben cine ätiologische Bedeutung zukommt, darüber können nur weitere Untersuchungen Aufschluss geben. Jedenfalls fordern sie auf, in ähnlichen Fällen mehr als bisher auf Amöbenfunde zu achten. - Celli und Fiocca fanden den männlichen Urogenitalapparat stets frei von Amöben. Dagegen erkannten sic im weiblichen Amoeba spinosa und vermicularis.

9. Auch in der Scheide bei Frauen fehlen sie nicht. - Wie vorhin erwähnt, constatirte sie Baelz daselbst, ferner Celli und Fiocea (A. spinosa und vermicularis). Die $\Lambda$. vermicularis bemerkten letztere auch in der Scheide einer krebskranken Frau. Rossi Doria fand bei Endometritis chronica glandularis ebenfalls Amöben. Ueber den Scheidenschleim von Thieren liegen keine Veröffentlichungen vor. 
10. Amöben in einem Abscess am Boden der Mundhöhle. Flexner machte 1892 eine Nittheilung über derartige Befunde bei einem 62 jährigen Manne, der, soweit sich dies feststellen liess, früher an Dysenterie litt. "Nach Exstirpation eines kleinen Knotens unter dem Zahnfleische des Unterkiefers entstand eine ausgedehnte entzündliche Schwellung am Boden der Mundhöhle, welche bis zum Angulus maxillae inferioris und bis zur Cartilago cricoidea reichte. Es bildete sich Eiter. In dem entleerten Eiter waren unter anderen auch Amöben, besonders in den Fetzen. Sie hatten körniges Plasma und Vacuolen, sie bewegten sich, Fortsïtze aussendend, in Kochsalzlösung ca. 15 Minuten und konnten durch Erwärmung des Objectglases auf kurze Zeit wieder bewegungsfähig gemacht werden. Kern undentlich. - Ferner hat Kartulis Amöbenbefunde publicirt aus einem Submaxillarabscess eines 43 jährigen Arabers in Alexandria. Es handelte sich $1 \mathrm{~m}$ eine Caries des rechten Unterkiefers. Der Eiter sowie die extrahirten Knochenfragmente enthielten neben Bakterien auch Amöben ron grobkörnigem, Erythro- und Leukocyten einschliessendem Protoplasma mit lebhafter Bewegung und schnell austretenden langen Fortsïtzen. Grösse 0,030-0,038 mm. Kerne und Vacuolen nicht deutlich sichtbar.

11. Von cinem in den verschiedensten Organen verbreiteten Vorkommen der Amöben berichten Nencki, Sieber und Wyznikiewicz bei pestkranken Rindern. Sie fanden dieselben nicht allein im Verdauungstractus, im Uterus- und Nasenschleim, sondern auch in den inneren Organen, wie Leber, Milz, Niere. Ueber die Form und Species machen sie keine näheren Angaben.

12. Ich selbst traf Amöben an gelegentlich der Untersuchung des Secretes eines schr ausgedehnten, eiternden Unterschenkelgeschwürs einer alten Frau Chr. R. im Dorfe B., welche sich lebhaft bewegten und durch die Art der Fortsätze als Amoebac spinosae documentirten. Die Frau hatte die Gewohnheit, da ,alle anderen Flüssigkeiten ihr Schmerzen verursachten", Grabenwasser zum Kühlen жu verwenden, und dürfte auf diese Weise ihre Anwesenheit in dem Uleus zu erklären sein, um so mehr, als in dem betreffenden Grabenwasser die Amoeba spinosa heimisch war.

13. Ein cinziger Fall ist notirt von einer Amöbenansiedelung auf der Haut bei Schafen mit sehwerer Hautaffection (Lendenfeld).

14. Schliesslich haben wir noch einer sehr wichtigen Publication zu gedenken von Leyden und Schandinn 1896. Es betrifft diese die "Leydenia gemmipara Schaudinn, ein nener in der Ascites- 
flüssigkeit des lebenden Menschen gefundener amöbenähnlicher Rhizopode".

Bei zwei auf der ersten medicinischen Klinik zu Berlin befindlichen Patienten, einem 22jährigen Mädchen mit starkem, bereits wiederholt punktirtem Ascites, nach dessen Entfernung regelmässig knollige Tumorèn im Abdomen gefühlt wurden, und einem 63jährigen an Nagenearcinom und $\Lambda$ scites leidenden Manne, fanden sich in ter durch die Punktion entleerten trüben Bauchflüssigkeit bei der mikroskopischen Untersuchung neben anderen Bestandtheilen grosse blasse, rundliche Zellen mit strahlen- oder borstenförmigen Ausläufern, erheblich grösser als Leukocyten und mit fettartigen Tropfen und gelbem Pigment ausgefüllt, meist in Nestern zusammenliegend. In den heissen Julitagen zeigten dieselben eine lebhafte Bewegung unter dem Ilikroskop. Auch beobachtete man, wie sie sich zu eigenthümlichen, netzförmigen Gebilden vereinigten, auf deren Ausläufern knopfartige Knospen aufsassen, die sich loslösten und wieder zu Zellgebilden entwickelten. Diese Bewegungsrorgänge liessen bei Zimmertemperatur ron $24-25^{\circ} \mathrm{C}$. sich 4-6 Stunden lang beobachten, selbst in einer Aseitesflüssigkeit, welche bereits $3-7$ Tage steril aufbewahrt gestanden hatte. Die Auffassung Leyden's, dass es sich hier um Lebewesen handelte, die der Classe der Protozoen angehörten, wurde von Dr. Schaudinn, Assistent am Berliner zoologischen Institut, einem gründlichen Kenner der Protozoen, bestätigt.

Schaudinn stellte fest, dass es sich in beiden Fällen um dicselbe Species eines parasitären amöbenähnlichen Rhizopoden handelt, den er zu Ehren seines ersten Beobachters und weil derselbe sich durch Knospung fortpflanzt, "Leydenia gemmipara Schaudinn" nannte.

Die Untersuchung geschah folgendermassen:

Sofort nach der unter allen aseptischen Cautelen ausgeführten Punktion wurde die trübe Ascitesflüssigkeit meist centrifugirt, ein Tropfen des Bodensatzes oder auch der uncentrifugirten Flüssigkeit auf einen Objectträger gebracht und mit einem Deckgläschen bedeckt, das durch vorhergegangenes Umschmelzen der Ecken in der Flamme verhindert wurde, einen Druck auf das Präparat auszuüben. Die Deckgläschen wurden darauf mit Wachs umzogen und bei $25^{\circ} \mathrm{C}$. Zimmertemperatur (Juli) oder im Thermostaten untersucht.

Nach Schaudinn's Untersuchungen haben diese Gebilde im contrahirten Zustand kuglige oder unregelmässig polygonale Gestalt mit höckeriger Oberfläche, von 3-36 " Grösse. Im nichtcontrahirten Zustand sind sie noch grösser. Sie besitzen eigene Bewegung und verändern, wenn auch langsam, ihre Gestalt. Sie senden ihre Pseudo- 
podien nach versehiedenen Richtungen aus. Dic Fortsaitye sind entweder hyalin, lamellös, oder körnig; fadenförmig; beide Formen treten gewöhnlich combinirt auf. Das Plasma ist dicht besetzt mit gelblich glänzenden, stark lichtbrechenden Körnern, ihr Aussehen bei durehfallendem licht ziemlich opak. Eeto- und Entoplasma sind nie seharf greschieden. Beim Aussenden der Fortsätze rückt das körnige Entoplasma allmälig in die hyalinen Lamellen. In letztere hinein treten Stränge körnigen Plasmas, welche sich über die Grenzen der Lamellen hinaus in das umgebende Medium ausdehnen und lange spitze Pseudopodien bilden. Thre Basen werden dann durch die lamellösen Plasmaplatten wie durch Schwimmhäute verbunden. Diese plattenartigen P'seudopodien sind eigenthümlich und crimern sehr an den von F. E. Schulze beschriebenen Placopus; es brechen bei beiden mehrere unter verschiedenen Winkeln zu einander gestellte und mit einander versehmelzende Lamellen auf der Oberfläche des Organismus hervor, dieselben schliessen trichterartige oder kappenförmige Hohlräume mit nach aussen gerichteter llündung cin. Während bei Placopus die Stränge mit körnigem Inhalt an den Lamellenkanten nur bis zur Grenze der Lamellen reichen, entwickeln sie sich bei Leydenia als lange filöse Fortsätze öfters darüber hinaus. Versehmelzung derselben zwischen verschiedenen Individuen findet häulig statt. Wine vorhandene Neigung zur Plastogamie liefert grosse Aggregat-Plasmodien. Als Einschlüsse im Plasma sind zu nennen Körner fettartiger Natur, eckige, krystallähnliche, von grünlichem Selimmer, vielleicht Exeretkörner, Nahrungsreste ete. Die Nahrung scheint aus Blutkörperchen zu bestehen, welche der Parasit umfliesst und aussaugt. Gewöhnlich besitzt die Leydenia mehrere Flüssigkeitsvaeuolen, eine pulsirende Vacuole (1/4 stündl. Contraction) und einen Kern.

Der Kern hat gewöhnlich $1 / 5$ der Grösse von dem Gesammtdurchmesser des Individuums und einen grossen stärker lichtbrechenden Kernkörper. Er tritt durch Färbung mit verdünntem Grenacherschen Hämatoxylin und mit Heidenhain'schem Hämatoxylin deutlich hervor. Durch die Färbung mit Thionin, Brasilin, Boraxcarmin sind im Centrum des Kernes gehäufte Chromatinkörner nachgewiesen worden. Die Fortpflanzung erfolgt durch Theilung und Knospung. Die Knospung der Amöben war in der Ascitesflüssigkeit zur Zeit so lebhaft, dass kaum ein Individuum ohne Knospe angetroffen wurde. In den kleinsten 3-4 " messenden Knospen ist der Kern gerade noch als Punkt zu sehen. Dic Kerntheilung geht der Plasmatheilung der Amöbe voran. Der Kern schnürt sich in zwei ziemlich gleiche Theile, wird hantelförmig und schnürt sich dureh, dann lösen sich die 
'Theile von einander; diese wachsen weiter und können sich sofort wieder theilen. In Anbetracht aller charakteristischen Eigenschaften setzt Schaudinn die Parasiten, was die zoologisehe Stellung anbelangt, in die Nähe des freilebenden Placopus. Ob dieser Parasit mit der Krebskrankheit etwas zu thun hat, darüber enthalten sich sowohl Leyden wie Sehaudinn jedes Urtheils, geben aber die Möglichkeit zu. Un diese Frage zum Austrag zu bringen, sind weitere Beobachtungen und Culturversuche nebst Impfungen durchaus nothwendig. J. P feiffer hat diese Veröffentlichung in der Münchener medicinischen Wochenschrift 1896 (No. 38. S. 894) kritisch besprochen. Er giebt die Parasitennatur der Jerdenia nicht ohne Weiteres zu. Er weist darauf hin, dass grosse voluminöse amöboide Zellen mit Körncheninhalt, mit Pseudopodienbildung, mit selbstständiger Ortsbewegung, mit Umfliessen der Nahıungskörper etc. vorkommen im Bläscheninhalt von Variola, Vaccine, Varicellen, Herpes zoster, Pempligus etc. und ähnliche Zellen von annähernder Grösse in dem Ausschlag von Hundestaupe, im Speichel bei Klauenseuche, im Auswurf bei Keuchhusten, bei Noma im Eiter, im trüben Pleuraexsudat und wahrscheinlich bei noch sehr vielen Exsudationsprocessen. Daher ist nach L. Pfeiffer's Insicht dic Leydenia kein Parasit, sondern ein Abkömmling von eincm Gewebe der Kranken, eine Exsudatzelle. Er betont, dass diese Zellen Abkömmlinge von Binde-, Muskel- und Epithelgewebe sein können. Er giebt dafür Jiteraturbeläge ${ }^{1}$ ) und bezeichnet im Gegensatz zu scinen früheren Anschauungen diese Art Zellen als Exsudatzellen zur Unterscheidung von den kleinen Leukocyten. "Alle diese Zellen", sagt er, „haben die einfache und die beschleunigte Kerntheilung, ihre Bewegungen unterscheiden sich in nichts von denen der Amöben, es ist cine active Bewegung des hyalinen Protoplasmas, dem das mehr oder weniger gekörnte Protoplasma passiv folgt. Eine pulsirende Vacuole haben sic nicht." - Schaudinn erwähnt aber ausdrücklich eine solche bei der Leydenia. Er sagt: .An flach ausgebreiteten Individuen kann man sich leicht ron dem Vorhandensein einer pulsirenden Vacuole überzeugen, ihre Contractionen erfolgen ziemlich langsam.* Die Klarstellung über die Jeydenia muss der Kukunft überlassen werden.

1) A. o. O. Kückenthal hat bei den Anneliden und Polychaeten für die in der Leibeshöhle frei umlıerschwimmenden Amöboidzellen den Zusammenhang mit Bindegewebszellen des Blutgefüsssystems nachgewiesen. Mletschnikoff lässt diese Amöboidzellen direct aus dem Huslielgewebe entstehen, z. B. bei der Sarcolyse des Froschschwanzes. - Er verweist ferner auf die neuerdings ron Grawitz untersnchte Lebenszähigkeit der Epithelialgebilde und deren Abkömmlinge. 
Dasselbe gilt von den anderen in diesem Capitel aufgezählten Amöben. Abgesehen davon, dass Täuschungen bei diesen Veröffentlichungen mit Leukocyten vorliegen können, ist der strenge Beweis zu bringen, ob ihnen cine pathogene Bedentung zukommt, oder ob sie nur secundäre Begleiter des betreffenden Krankheitsprocesses sind. Auch hier kann nur die von Koch aufgestellte strenge Forderung: Reinzüchtungen, Impfungen und Lirzeugen derselben Krankhcit, eine endgiltige Lösung bringen. Ausser den Bacterien ist auch diesen Gebilden eine grössere Aufmerksamkeit als bisher zu schenken im ungefärbten frischen Präparat. Sie verdienen, - nicht mehr übersehen zil werden.

Capitel V.

\section{Die Dysenterieamöbe.}

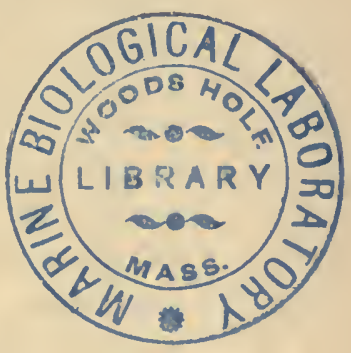

Die Aetiologie der Dysenterie hat eine interessante Geschichte. Bercits Lambl in Prag hatte 1860 im Schleim eines zweijährigen an Enteritis verstorbenen Kindes amöbenartige Gebilde von 4,6-6,2 " bemerkt. 1870 sahen Lewis und Cunningham bei Cholerafällen und anderen Darmkrankheiten in Indien Amöben. 1875 machte Loesch die erste ausführliche Mittheilung von Amöben bei einem echten Falle von Dysenterie. Sie erschien in Virchow's Arehiv. Es handelte sich um einen 24 jährigen Bauer in Petersburg, welcher schon längere Zeit an heftigen dysenterischen Erscheinungen litt. Er fand im Stuhl ausser weissen und rothen Blutkörperchen, zerfallenen Darmepithelien, Zellendetritus, Bacterien, Speiseresten etc. zellenartige Gebilde von rundlicher, ovaler, birnförmiger und unregelmässiger Form, sich immer bewegend und den Ort wechselnd. Nach den Bewegungen war es ihm kein Zweifel, dass er es nicht mit pathologisehen oder physiologischen zelligen Elcmenten, sondern mit thierischen Lebewesen, und zwar Amöben, zu thun hatte. Er giebt ron diesen folgende Beschreibung: Die im Allgemeinen rundliche Leibessubstanz hat grobkörniges, theilweise hyalines Protoplasma. Das Ectosark ist beim Ruhezustand kaum sichtbar, bei der Pseudopodienbildung hyalin hervortretend. Im Endosark finden sich feine Granula und Nahrungsreste, wie Bacterien, Amylumkörnchen, Darmepithelzellen, rothe Blutkörperchen, Lcukocyten etc., auch Zinnoberpartikelchen wurden in 
ihnen bemerkt, nach Ëinverleibung solcher per Klysma. Die „Amoeba coli“ besitzt einen runden blassen, bläschenförmigen Kern, ein Kernkïrperchen, das bei der Bewegung seine Stellung wechselt. Im Innern bemerkt man ausserdem Vacuolen, $1-2$ und mehrere. Bei der Beobachtung sind dieselben bald grösser, bald kleiner und nehmen bei der Bewegung statt der runden öfters eine ovale, länglich bohnenförmige oder unregelmässige Gestalt an. Contractile Vacuolen fehlen. Die Pseudopodien erscheinen in geringer Anzahl. An einer Stelle der Oberfläche erhebt sich ein glasheller Höcker, der sich weiter erstreekt und in den die körnige Substanz nachrückt. Einzichen und Aussenden der Scheinfüsse wechselt ab. Die Ortsveränderung ist eine lángsame. Innerhalb einer Mlinute legen sie eine Strecke zurïck, die der Länge des Körpers entspricht. Mit Anilinfarben färben sic sich weniger gut als mit Eosin. Die Grösse schwankt zwischen circa 15 bis $35 \%$. Die Zahl derselben in diesem Falle war eine enorme. Lösch sah bei ciner 500 fachen Vergrösserung in Gesichtsfeld 50 bis 60 Exemplare. Er brachte sie mit rler Krankheit in Beziehung, bezeichnete sie jedoch nicht als direkte lirreger der Ruhr. Er war der Ansicht, dass durch die Amöben heftige uleerative Entzündungen im Darmkanal hervorgerufen oder bei schon bestehender Darmaffection die Heilung hingezogen worden könne. In den folgenden Jahren wurden mehrfach Amöben bei Darmkrankheiten constatirt, so von Normand 1879 bei zwei an Enteritis leidenden Patienten in Hongkong, von Sonsino bei einem Kinde in Cairo; 1879 entdeckte sie Grassi bei Dysenterie-, Typhus-, Cholera-, Pellagrakranken in Rovellaria, Messina, Mailand, Pavia. 1882 erwähnt sie Perroneinto bei einem Fall von Enteritis in Mailand. Robert Koch stellte sie fest 1883 in Egypten bei 5 Dysenteriefällen, in der Tiefe ler Ulceration und im angrenzenden Gewebe, ebenso in Indien. Fine grössere Aufmerksamkeit wurde diesen Lebewesen zu 'Theil, als Kartulis 1885 sie mehrfach in den Darmentleerungen bei endemischer Dysenterie antraf und, da er sic bei anderen Darmkrankheiten, Typhus, Tuberculose etc. nicht fand, als Träger des Dysenteriecontagiums proclamirte. Darauf hat Kartulis dieser Affection sein besonderes Interesse gewidmet; es erschienen mehrere Publicationen und 1889 verfügte er bereits über ein Krankenmaterial von 500 Fällen. Er constatirte die Amoeba coli auch in Darmschnitten, sowie in dem Eiter dysenterischer leberabscesse und deren Wandungen. Die Folgezeit bestätigte seine Angaben. Eine Reihe von Forschern berichteten darüber, und es zeigte sich, dass die geographisehe Verbreitung eine weit grössere war. Nan stellte Amüben fest in den Dejectionen sowohl als in Darm- 
schnitten und Leberabscessen Dysenterischer. Hlawa fand sie in Prag (60 Fälle endemischer Dysenterie); Osler (Baltimore), Councilman, Lafleur, Simon, Musser, Eichberg, Dock, Stengel, Lutz in Amerika, Calandruceio und Fenoglio in Italien und Sardinien, Vivaldi in Padua, Massiutin in Kiew, Kartulis in Athen, Cahen in Graz, L. Pfeiffer in Weimar ${ }^{1}$ ), Kruse und Pasquale in Egypten, Lobas in Sachalin, Nasse in Florida, Rizzozero in Italien, Harold und Curnow in einem von Indien nach London versehleppten Falle, Kováes in Oesterreich (ron Sumatra eingesehleppt), Baelz in Japan, Ebstein in Prag ete. Da die Stimmen aus den versehiedensten Erdstrichen sich mehrten, so wurden die Amöben immer wahrscheinlicher in ursächlichen Zusammenhang mit der Ruhr gebracht, um so mehr, als von gelungener Uebertragung auf Thiere mittelst Injection von dysenterisehem Stuhl vielfach berichtet wurde.

Diese Thierexperimente datiren bis auf Loesch zurïck. Schon er hat an vier Hunden per os und rectum $1 \frac{1}{2}$ Unze amöbenhaltiger Fäees cingebracht; ron diesen erkrankte ein Hund an Dysenterie mit blutigem Stuhlgang; die Section 18 Tage später ergab im Rectum Röthung und Ulecra mit Amöben. Die drei anderen Hunde blieben gesund. Ferner latte Hlava positiven Erfolg bei 4 Katzen und 2 Hunden, während die Uebertragung auf Kaninchen, Hühnern, Meerschweinchen erfolglos war. Ebenso erreichte Kartulis durch mehrfache Experimente an Katzen die Erzeugung von Dysenterie. Kruse und Pasquale beobachteten unter 16 Versuchen 8 mal ein positives Resultat. Im bejahenden Sinne fielen auch die Versuche ron Quincke und Roos aus. Bei 8 Katzen wurden mittelst Nélatonkatheter per rectum dysenterische Fäces eingespritzt. Es trat Amöbendysenteric ein mit sehr ausgesprochener ulcerativer Entzündung der Dickdarmschleimhaut; schon vom 4.--6. Tage an zeigten sich Amöben. Zwei Katzen wurden per os Amöbeneysten eingeführt, diese erkrankten an Dysenterie. Auch Kovics experimentirte an Katzen, sowie verschiedene andere Forscher, welche theils negative, theils positive Resultate erhielten. Besonders bestärkten die mit bacterienfreiem Leberabscesseiter gelungenen Uebertragungsversuche, welchen Experimenten man den Werth von Reinculturinjectionen beilegte, noch mehr die Ansicht, dass in der That die Amoeba coli die Dysenterie verursache.

1) Ich constatirte Amöben bei einer unter Kindern auftretenden Rulı mit blutigen Stühlen 1896 in dem Dorfe Fysdorf (Kreis Luckau), welche den 1887 von L. Pfeiffer beschriebenen und abgebildeten ähnlich sind. 
Es wurden jedoch bald Gegenstimmen laut, welche die pathogene Bedeutung der Amöben bei Dysenterie anzweifelten. Man hob zunächst hervor, dass nicht in jedem Fall von Tropendycenterie Amöben rorkämen. Auch Kartulis hat nicht in jedem der untersuchten Fälle diese Parasiten bemerkt. Kruse und Pasquale fanden sie nur in $4 / 5$ der untersuchten Patienten, Celli und Fiocea auch nur in einem gewissen Procentsatz. Ebenso wurden auch nicht in jedem Falle von Jueberabscess Amöben constatirt.

Sodann wurden die Uebertragungen auf. Thiere nicht als correct anerkannt. Ein Ilal erkrankten nicht alle Thiere, ansserdem ist die Interpretation dieser Uebertragungsversuche nicht stichhaltig. Der Injectionsstoff war keir: absolut reiner, es wurden auch andere Mikroorganismen mit einverleibt, überdies besass der Darm bereits vorhandene Bacterien. Kartulis legte grosses Gewicht anf ein positiv gelungenes Experiment bei einer Katze, welcher er eine in Strohinfus gezïchtete Reincultur per rectum einspritzte, mit Verschluss des Anus. Die Katze erkiankte, in den Ausleerungen befanden sich Amöben, sie starb am 19. Tage. Im Dickdarm zeigten sich mehrere kleine punktförmige Hämorrhagien und Geschwüre. Der Darminhalt bestand aus Zellenpigment, rothen Blutkörperchen, Leukocyten und viclen Amöben; welche ron den mensehlichen Dysenterieamöben nicht zu unterscheiden waren. Aber auch dieser anscheinend schlagende Beweis für die Pathogenität dieser Parasiten wurde hinfällig dadurch, dass die Reincultur nicht als solche anerkannt wurde, worauf wir später noch znrïckkommen.

Es traten ferner bei der Untersuchung dysenterischer Fäces, wie Quincke, Roos, Piceardi zeigten, auch andere Protozoen wie Flagellaten, Cercomonaden etc. zu Tage. Amöben wurden schliesslich auch bei nichtdysenterischen Darmerkrankungen beobachtet, so von Grassi bei verschiedenen Intestinalkrankheiten, ron $\mathrm{Cuningham} \mathrm{bei}$ Cholerakranken (unter andern auch bei Pferden und Kühen), ron Grassi bei Diarrhoe, von Casagrandi, Barbagallo-Rapisardi bei Typhus ete. Ja sogar, was einen Haupteinwurf bildete, man constatirte sic vielfach auch bei ganz gesunden Personen. Cuningham, Grassi, Celli und Fiocea, Calandruccio wiesen darauf hin. Von Schuberg wurde diese Thatsache voll und ganz bestätigt. Nach Verabreichung von Carlsbader Salz bei 20 völlig gesunden Personen waren in etwa der Hälfte der Fälle im Stuhl Amöben vorhanden, während diese im festen Stuhl fehlten. Nach seiner Ansicht scheinen dic Amöben beim Weitervorrücken des Darminhaltes in Folge der physikalischen und chemischen Bedingungen entweder sich zurückzu- 
zichen oder aber in Folge der sauren Gährung in den Kothballen unterzugehen. Er glaubt, dass dieselben, wenn nicht überhaupt regelmässige, so doch sehr häufige Nitbewohner des Darmes sind.

Man hat deshalb behauptet, dass möglicherweise verschiedene Arten von Amöben im menschlichen Darm vorkommen, harmlose und schädliche. Zu dieser Ansicht haben hauptsächlich die Untersuchungen von Kruse und Pasquale, sowic von Quincke und Roos beigetragen. Im Sommer 1892 begaben sich Kruse und Pasquale nach Egypten zum Studium der Dysenterie und des Leberabscesses. Sie begegneten in der Mehrzahl der untersuchten Fälle Amöben und kamen zu dem Sehluss, dass diese Parasiten die Ruhrerreger sind, aber sie machten einen Untersehied in den Arten. Sie entdeckten nämlich in den normalen Fäces ihres Darmes morphologisch von Dysenterieamöben nicht differente Formen, welche für Katzen nicht pathogen sind. Sie nahmen in Folge dessen zwei verschiedene Arten der Amoeba coli an, eine unschuldige (Grassi, Calandruceio, Schuberg), für Menschen und Katzen unschädliche, und zweitens eine pathogene Art, wclche für Katzen stets pathogen und als die Ursache der endemischen Ruhr in Egypten zu betrachten ist.

Wichtig in dieser Beziehung ist dic Arbeit von Quincke und Roos (1893) über Amöbenenteritis; sie beobachteten in Kiel 2 Fälle, von denen der eine wahrscheinlich von einer Infection in Palermo herrührte, der zweite aber am Ort entstanden war. Bei dem ersten Patienten zeigten sich Amöben von $0,020-0,025 \mathrm{~mm}$ Grösse, mit feingetrübtem Plasma, kugeligem Kern, mit Einschluss von rothen Blutkörperchen; die Cysten derselben waren kugelig, doppelt contourirt. Diese Amöben waren für Katzen pathogen. Bei dem zweiten Falle waren die Amöben etwas grösser $(0,04 \mathrm{~mm})$, ihr Protoplasma grobkörniger; sie hatten Vacuolen, der Kern war nicht so scharf contourirt, die Bewegung nicht so lebhaft; im Innern beobachteten sie nie rothe Blutkörperchen. Injection dieser Amöben bei Katzen führte nicht zum Tode. Dieser Punkt und die verschiedenartigen Krankheitsbilder der Patienten bewogen sie zu der Annahme zweier verschiedener Amöbenarten. Dazu kamen Untersuchungen bei gesunden Menschen nach Schuberg's Vorgange, welche Amöben lieferten, die denen des zweiten Falles ähnlich waren. Auch diese waren für Katzen nicht schädlich. In Folge dieser Bcobachtungen unterschieden Quincke und Roos 3 beim Menschen parasitäre Amöbenarten: 1. Amoeba coli Loesch s. coli felis, klein, feingranulirt, für Mensch und Katze pathogen; 2. Amoeba coli mitis, gross, grobgranulirt, für die Menschen, nicht jedoch für Katzen pathogen; 3. Amoeba intestini 
vulgaris, gross, grobgranulirt, weder für Menschen noch für Katzen pathogen. Auch Blanchard hatte schon vorher Artunterschiede gemacht. Andere Amöbenuntersucher hingegen haben seitdem bemerkenswerthe Unterschiede zwischen den Dysenterieamöben und den Amöben der Gesunden nicht feststellen künnen. Jedenfalls sind die morphologischen Differenzen in Betreff der Grösse, Structur etc. noch nicht genügend klargestellt, dazu bedarf es noch weiterer Untersuchungen, besonders aber Reineulturen der betreffenden Amöben.

Schliesslich wurde der Amöbenätiologic der Ruhı ein starker Stoss versetzt von den Forschern, welche bei Ruhruntersuchungen überliaupt kcine Amöben, sondern nur Bakterien feststellten. Diese erweisen sich bereits als sehr zahlreich. Schon früher hatte Klebs kurze Bacillen gefunden. Marfan und Lion züchteten aus dem dysenterischen Darm Bacterium coli commune, Babes cultivirte Streptokokken, Proteus vulgaris, cholera- und typhusähnliche Bacillen; Petrone 1884 Kokken, mit deren Culturen er 2 Hunde dysenteriekrank gemacht haben will. 1885 Condorelli-Mangeri und Aradas erhielten in einer Ruhrepidemie Bacillen, die sie auch im Brumenwasser wieder beobachteten. Chantemesse und Widal 1888 isolirten in 5 Fällen von tropischer Ruhr ( 1 aus Tonkin, 4 aus Senegal und Cayenne) einen Diphtheriebacillus mit abgerundeten Enden, der auf den gebräuchlichen Nähıböden wächst und Anilinfarben schlecht annimmt. Culturen desselben per os et anum injicirt, brachten eine dysenterieähnliche Entzündung hervor. Ilaggiora 1891 in Turin entdeckte in dem Schleim dysenterischer Fäces rerschiedenartige Bacterien, wie Bacterium coli commune, fast stets in Gesellschaft ron Proteus vulgaris, in reichlicher Mlenge, seltener Eiterkokken, Bacillus pyocyaneus ete.; 1892 isolirte $0 \mathrm{gata}$ in Japan bei einer Ruhrepidemie ein kleines Stäbchen, welches nach Gram färbbar war, die Nährgelatine verflüssigt und für Thiere pathogen ist. Reinculturen desselben, per os et anum injicirt, erzeugten bei Meerschweinchen und Katzen Entzündung auf der Dickdarmschleimhaut; Laveran 1893 in Paris constatirte verschiedene Bacterien, olne jedoch einer derselben eine specifische Rolle zu ertheilen. Silvestri in Nebbiuno (Lago Maggiore) erzielte mehrere Bakterien, darunter $2 \mu-4 \mu$ lange, stark bewegliche Diplokokken, welche per rectum in Culturen eingebracht, bei Hunden und Katzen heftigen Darmkatarrh hervorriefen. Kruse und Pasquale eruirten neben Amöben hauptsächlich Streptokokken. Zancarol in Alexandrien stellte ebenfalls Streptokokken fest, deren Injection chronische Diarrhöe rerursachte. Arnaud in Tunis erzielte Bacterium coli commune und will durch Einimpfung dieser Culturen 
bei 5 Hunden Dysenterie zu Stande gebracht haben. Bertrand und Baucher erhielten bei ihren Untersuchungen in Cherbourg sechs Bactericnarten: Vibrio septique, B. pyocyaneus, Staphyl. pyog. aur. alb. und citreus, Staphyl. nonliquefaciens und Sarcina lutea. Janowski fand gelegentlich einer Warschauer Ruhrepidemie (1892-94) niemals Amöben, sondern nur Bakterien.

Wir sehen, von verschiedenen Forschern sind die verschiedenartigsten Bakterien, Kokken, Bacillen, Diplokokken etc. als ursächliches Homent der Dysenterie rerantwortlich gemacht worden. Dem gegenüber stehen eine Reihe von Untersuchungen, die Amöben gefunden haben. Man kann nicht annehmen, dass letztere übersehen worden sind. Man kommt unwillkürlich zu der Folgerung, dass das typische Bild der Dysenterie durch verschiedene Ursachen hervorgerufen werden kann. Eine sehr gründliche, die gesammte Literatur berücksichtigende, kritische Arbeit zur Aetiologie der Ruhr hat neuerdings Janowski in dem Centralblatt für Bakteriologie und Parasitenkunde geliefert. Auf Grund seiner umfangreichen Studien fasst er sein Gesammturtheil folgendermaassen zusammen: "Die Dysenterie ist eine ätiologisch nicht einheitliche Krankheit und wird aller Wahrscheinlichkeit nach nie durch die Einwirkung eines einzelnen Parasiten, sondern durch Zusammenwirkung mehrerer Varietäten auf den Organismus hervorgebracht. Aus den bis heute in der Literatur vorhandenen Daten kann man schliessen, dass die Ursache der gewöhnlichen Dysenterie (epidemischen) irgend eine Bakterienassociation ist; eine ihrer Formen aber, die sich in klinischer und anatomischer Hinsicht von den ïbrigen unterscheidet, die sogenannte Tropendysenterie, wird aller Wahrscheinlichkeit nach durch die Association einer bestimmten Amöbenspecies mit Bakterien hervorgerufen."

Anderer Ansicht sind Celli und Fiocca; sie nehmen einen einheitlichen Erreger der Ruhr an auf Grund ihrer Untersuchungen einer grösseren Zahl von Fällen typischer Dysenterie. Sie betrachter. die Amöben nicht als directe Ursache dieser Krankheit, da es Fälle giebt von epidemischer, endemischer und sporadischer Dysenterie ohne irgend welche Amöben. Durch Impfung von dysenterischen Faeces oder von Culturen, ¿die Amöben und Bacterien enthalten, lässt sich eine amöbenfreie Dysenterie erzeugen, ebenso kann man die Amöben durch Erhitzen auf 59-600 abtödten, auf diese Weise nur Bacterien und ihre Gifte einimpfen und gleichfalls Dysenterie hervorbringen. Die Amöben sind in der Umgebung sehr verbreitet; in Egypten ist die Amoeba coli sehr häufig, daher ihre grosse. Häufigkeit im Darm der Dysenterischen; sie findet sich in analoger Weise im Darm der 
Gesunden, die weder Dysenteric haben, noch hatten. In den dysenterischen Dejectionen ist stets vorhanden das Bacterium coli commune, gewöhnlich in Gesellschaft einer typhusähnlichen Varietät, häufig auch von Streptokokken und manchmal auch eines Proteus. Experimentell lässt sich per os et rectum die Ruhr mit dem Bacterium coli und manchmal auch mit den beiden anderen Arten hervorbringen; es seheint sogar nach ihrer Ansicht, dass das Zusammenwirken der beiden letzteren eine der Ursachen im Darm und vielleicht auch in der Umgebung sei, die das Bacterium coli commune in die Varietät des Bacterium roli dysenteriac umwandelt, welches sich dann mit dieser specifischen Virulenz von Thier zu Thier dureh eine ganze Reihe erhält. Diese Varietät unterscheidet sich hauptsächlich dadurch, dass sie ein Toxin ausscheidet, welches fähig ist, die typische dysenterische Localisation hervorzubringen, wenn es per os et anum gegeben oder in das subcutane Bindegewebe eingeimpft wird. Celli hat diese Untersuchungen noch weiter fortgesetzt und formulirt seine Ansicht in einer späteren sehr gründlichen Arbeit in folgenden Sätzen: „Nit dysenterischen Fäces, mit Bacterium coli dysentericum von diesen gezüchtet, mit einem T'oxin dieses Bacteriums lässt sich bei Fleischfressern eine experimentelle Dysenterie zu Stande bringen. Die dysenterische Infection bei Menschen wird zuerst von einem Toxin dieses Bacterium coli dysentericum erzeugt. Die Darmgeschwüre sind von den pyogenen Bacterien des Darmes abhängig. Dieses Toxin kamn eine pyogene, dysenterische oder marantische Wirkung haben. Mit fortschreitender Dosis desselben können Thiere widerstandsfähig gegen die marantische und dysenterische Wirkung, aber nicht gegen die pyogene Wirkung werden. Die Widerstandsfähigkeit ist aber nur vorübergehend. Dieses Toxin kann man im Blute dysenteriseher Menschen und Thiere finden. Galli-Valerio kommt in einer Arbeit über die Aetiologie einer Serumtherapie der menschlichen Dysenterie zu ähnlichen Schlüssen. Er untersuchte verschiedene Krankheitsfälle in Valtellina und constatirte neben Amöben Bacillen, die nichts Anderes sind, als eine Varietät von Bacterium coli. Culturen desselben können eime experimentelle Dysenterie bei Hühnem und Hunden erzeugen. Mit wiederholten subcutanen Impfungen einer Cultur dieses Bacterium coli dysentericum bei Hunden lässt sich vollständige Immunität erzielen; mit dem Serum dieser immunisirten Hunde sind Meerschweinshen und Hunde gegen Infection mit Bacterium coli zu schützen.

Gegen die Theorie eines einheitlichen Erregers der Ruhr erhebt Kartulis Einspruch. Er spricht in seiner Schrift „Die Dysenterie": worin or seine Ansichten im Zusammenhange bespricht und vertheidigt, 
die Ueberzengung aus, dass es rerschiedene Formen der Rulır gicbt und auch verschiedene Erreger. Die epidemische Ruhr hält auch cr bakteriellen Ursprungs, es scheinen verschiedene Bakterien den einzelnen Epidemien zu Grunde zu liegen. Am meisten schuldbelastel ist das Bacterium coli commune. Die Ansichten der einzelnen Forscher gehen doch sehr auseinander, eine Einigung in Betreff des specifischen Mikroben hat sich noch nicht endgültig feststellen lassen. Anders die endemische oder Tropendysenterie. Hier hält er an seiner Amöbentheorie fest und vertheidigt sie gegen die Gegner. Es ist ron verschiedenen Seiten der Einwand gemacht worden, dass die Amöben nicht im Stande wären, Abscesse hervorzurufen und die Darmwand in so heftiger Weise zu schädigen. Es fehlt dazu, wie Baumgarten bemerkt, das Analogon. Kartulis aber vindicirt ihnen einen ziemlich breiten Raum bei der Genese der dysenterischen Veränderungen, des katarrhalisch entzündlichen wie des Verschwärungsprocesses. Nach ihm führen die Amöben durch den fortgesetzten Reiz, welchen sie auf die Dickdarmschleimhaut ausüben, eine Zerstörung des Epithels herbei, sie dringen dann durch die Zwischenränme (Lymphbahnen) der schlauchförmigen Drüsen ein und verursachen Entzündung, ob durch die Bewegung oder durch ein abgeschiedenes Gift, ist bis jetzt nicht klar. Das weitere Vordringen der Parasiten geschieht mit Durchbrechung des Muscularis mucosae. Kartulis nimmt an, nach Präparaten zu urtheilen, dass dieselben in einzelnen Exemplaren die Lymphbahnen der Muscularis mucosae passiren, um in die Submucosa zu gelangen. Hier besonders finden Amöbenansammlungen statt. Es erfolgt eine Einschmelzung der Submucosa. Durch die Erweichung der Muscularis mucosae und fortschreitende Zerstörung der Drüsenschicht bildet sich eine Oeffnung in der Schleimhaut. Diese ist zuerst nur gering, während der Substanzverlust in der Submucosa durch Vordrängen des erweichten Gewebes seitens der Amöben die Geschwürswände unterminirt. Kartulis glaubt, in Bezug auf die Frage, ob Bakterien oder Amöben bei der Bildung dieser Processe besonders betheiligt sind, was die uncomplicirten typischen Dysenteriegeschwüre anbelangt, die Bakterien ausschliessen zu müssen. Als Ausgangspunkt der Ulcera betrachtet er nicht nur die Submucosa allein, auch die Solitärfollikel, wenn auch seltener, lässt er daran theilnehmen. Die typischen Geschwüre der Amöbendysenterie besitzen verschiedene Grösse und Form, sie haben im Allgemeinen aufgetriebene Ränder und reichen bis in dic Submucosa, seltener bis an die Museularis oder gar die Serosa. Kartulis rechnet dazu folgende Formen: 1. Kleine Höhlen in der Submucosa, 2. runde, tiefe Geschwüre mit unterminirten 
Rändern, 3. unregelmässige Geschwüre mit unterminirten Rändern, 4. Gesehwüre verschiedener Grösse und Form mit nekrotischem Schorfe, 5. Folliculargeschwïre, 6. kleine Folliculargesclıwüre. Die fibrinösen, diphtheritischen oder croupösen Exsudationen, welche den Verschwärungsprocess begleiten können, sind nach Kartulis' Neinung secundärer Natur und bakteriellen Ursprungs. In Bezug auf die Einwürfe, die seiner Amöbentheorie im Allgemeinen gemaclit worden sind, entgegnet er Celli und Fiocea, dass er ihre Versuche bis aufs Einzelnste nachgeprüft und nicht bestätigt gefunden hat. Casagrandi und Barbagallo legen Gewicht darauf, dass die Einführung von amöbenhaltigen Fäces nach vorheriger Abtödtung mit Aqua destillata bei jungen Katzen ohne Erfolg ist. Kartulis entgegnet auf Grund ron Nachprïfungen, dass die egyptische Amoeba coli destillirtes Wasser sehr gut vertrage und mit destillirtem Wasser versetzte Amöbenfäces wie sonst auf Katzen wirken. Celli und Fiocea geben in ihren Schlussätzen an, dass sie mit Culturen von Bacterium coli dỵsentericum experimentell Dysenterie erzielt hätten; Kartulis gelang es nicht, mit aus endemischer Ruhr gezïchteten Colibacillen dasselbe zu erreichen. Ëne Hauptstütze für die Pathogenität der Amöben ist für Kartulis das Experiment von Kruse und Pasquale, welches auch or bestätigt gefunden hat, wonach intrarectale Injection von bakterienfreien amöbenhaltigen Leberabscesseiter bei Katzen Dysenteric erzeugte, gleichsam im Sinne einer Reincultur wirkend. Celli und Fiocea beanstanden die hier betonte Sterilität des Eiters; sie wenden ein, dass er nur anf Agar gezüchtet worden sei; auf Bouillon gezüchtet, sei derselbe doch bakterienhaltig. Kartulis erzielte auf beiden Nährböden im gegebenen Falle keine Bakteriencolonien. Auch Peyrot und Roger betonen bei ihrem beobachteten Leberabscess der Ruhr, dass auf den verschiedensten Nährböden derselbe sich als steril erwies. - Eine Reihe von Forschern ausser Celli und Fiocea, wie Grassi, Blanchard, Cunningham, Schuberg, Casagrandi, Barbagallo-Rapisardi ete., halten dic im gesunden und dysenterischen Darm gefundenen Amöben für nicht verschieden, sic sprechen diesen jede Pathogenität $a^{1}{ }^{1}$ ). Kartulis giebt zwar zu, dass Amöben

1) Casagrandi und Barbagallo sowie Fiori haben mit den auf Culturböden gezïchteten Amöben Versuche an gesunden und enteritiskranken Menschen sowie Katzen gemacht. Diese wurden im beweglichen und encystirten Zustand eingefülırt; selbst wenn sie sich entwickelten, blieben sie nicht viele Tage im Darm beweglich. - Calandruccio verschlnckte Amoeba coli im Cystenstadium, sie erhielten sich längere Zeit im Darm; er fand sie nach 12 Tagen in seinen normalen Entleerungen, 
auch bei Gesunden vorkommen. Diese seien aber, wie Kruse und Pasquale, Quincke und Roos gezeigt haben, verschieden von den dysenterischen und dürfen als nicht pathogene, harmlose Parasiten des Darmes betrachtet werden. Schliesslich macht er überhaupt den Gegnern den Torwurf, dass mit Ausnahme von Celli und Fiocea die endemische Ruhr Niemand in den lıeissen Gegenden selbsi studirt habe; letztere wiederum hätten das Material nicht nach jeder Hinsicht genau studirt, die pathologisch-anatomischen Verhältnisse nicht an Darmsehnitten näher verfolgt etc. Resumirend fasst Kartulis die Argumente für die Pathogenität der Dysenterieamöben in folgenden Sitzen zusammen: 1. Das constante Vorkommen der Amöben in jedem Falle von endemischer Ruhr; 2. das Vorkommen der Amöben in den dysenterischen Geschwürswandungen, ferner das Fehlen derselben bei Darmverschwärungen anderer Natur; 3. die. mit amöbenhaltigen Fäces dysenterischen Ursprungs stets gelingenden Uebertragungen der Dysenterie auf Katzen: 4. die mit amöbenhaltigem, von anderen Organismen aber freiem Leberabscesseiter dysenterischen Ursprungs gelingende Uebertragung der Dysenteric auf Katzen; 5. das negative Resultat des Versuches (Celli und Fiocea, Galli-Valerio ausgenommen) mit anderen im dysenterischen Stuhle vorkommenden Nikroben bei Thieren Dysenterie hervorzurufen; 6. das negative Resultat des Versuches mit anderen bei gesunden Menschen vorkommenden Amöben Katzen zu inficiren.

So sehen wir, wogt der Streit über die Aetiologie der Rulır noch hin und her; die widersprechendsten Meinungen stehen sich entgegen; aber das ist klar, diese Streitfrage lässt sich nicht auf dem Papier ausfechten bei noch so peinlicher Zusammentragung des gesammten literarischen Materials; es kanı nur zum endgültigen Abschluss führen eine Reincultur der Dysenterieamöben und die durch diese erreichte Erzeugung derselben Krankheit. Das ist der einzig mögliche exacte Beweis.

Erörtern wir zum Schluss die Frage: Sind die Dysenterieamöben bereits in Reinculturen geziichtet worden? so müssen wir mit Nein antworten. Es ist dies von einigen Forschern behauptet worden. Kartulis sagt: „Die Dysenterieamöben lassen sich auf unseren Nährböden nicht züchten. Nur in alkalischen Strohabkochungen gelingt es, wenn auch sehr selten, unreine Culturen zu erhalten. Unter Hunderten von Versuchen ist es mir nur einige Nale gelungen, die Dysenterieamöben in Strohabkochungen zu züchten. Einige Forscher, Schuberg, namentlich Kruse und Pasquale, halten, dieselben für Strohamöben. Demgegenüber bemerke ich, dass ich 3 Katzendärme 
besitze, welehe von Thieren herrühren, die mit derartigen Culturen inficirt waren. Eine Cultur stammt aus einem mikrobenfreien und amöbenhaltigen Leberabscesse. In den Geschwürswandungen der inficirten Thiere waren die Amöben fast in Reincultur vorhanden. Tivaldi gelangte auch mit seinen Culturversuchen zu ähnlichen Resultaten." Casagrandi und Barhagallo erkennen diese Kartulisschen und Vivaldi'schen Culturen nicht als ächte an, ebenso nicht die von Piccardi. lis sind alle möglichen ähnlichen Amöben, „nur nicht die eine ohne contractile Vacuole und mit mehrkerniger Cyste". Wie sehon erwähnt, wollen Celli und Fiocea unter anderen auf künstlichem Nährboden cultivirte Amöben auch die Amocba coli cultivirt haben. Sie beschreiben dieselbe als eine Varietät der Amoeba lobosa folgendermassen: „Sie stammt aus der Erde (aus Belluno) in der Nachbarschaft von dysenterischen Fïces, aus Wasser in dem Nilcanal, von wełchem dasselbe nach Alexandria hingeleitet wird, aus dem Darm Gesunder und an Dysenterie sowie an anderen Krankheiten Leidender. Im amöboiden Stadium haben sie eine lobuläre Gestalt (Tipo loboso), d. h. schicken lobuläre, hyaline, verhältnissmässig zahlreiche Pseudopodien aus; ihre Bewegungen sind nicht sehr lebhaft; ihre Grösse beträgt $4-8$ "; sie besitzen ein gleichmä̈ssig feinkörniges Entoplasma, ein spärliches, hyalines Ectoplasma, einen bläschenförmigen Keru, der nicht immer eine Vacuole enthält. Sie pflanzen sich durch Theilung fort. In Ruhestadium hat die Amoeba coli einfache Contouren, ein gleichförmig feinkörniges Protoplasma; ihre Grösse beträgt 1,5-2 “. Im encystirten Stadium besitzt dieselbe doppelte Contouren; die innere derselben ist dicker als die äussere, der Inhalt der Cysten ist feinkörnig. Was den Entwicklungscyklus anbelangt, so keimen die Amöben nach 12-15 Stunden aus den Cysten aus und nehmen amöboide Gestalt mit den dementsprechenden Bewegumgen an; nach 40-48 Stunden sind einzelne Amöben schon abgerundet und nach $60-65$ Stunden bereits alle eneystirt oder degenerirt." Wenn man, um nur einen Punkt hervorzubeben, auch erwägt, dass im Grossen und Ganzen die Amöben auf den künstlichen Nährböden sich kleiner repräsentiren, so stimmt doch die von Celli und Fiocea angegebene Grösse ihrer Amoeba coli von 4-8 " nicht überein mit der von Lösch angegebenen und von anderen Autoren bestätigten Grösse von $15-35 \|^{1}$ ). Es handelt sich

1) Ebenso stimmen die Grössenverhältnisse von Amoeba coli und der $\mathrm{Auer}$ bach'schen Amoeba princeps, an die Lösch dachte, nicht überein. Nach Auerbach ist die lelztere in liugeliger Form $70-140 \mu$, während Amoeba coli 
auch hier nur um eine ähnliche Form. Ganz abzuweisen sind nach Casagrandi und Barbagallo die Beyerinck'sche Amoeba zymophyla und die Schardinger'sche Amoeba coli, welche diese Autoren fïr möglicher Weise identisch mit der Dysenterieamöbe ansehen. Auch diese haben nur eine entfernte Aehnlichkeit. Kurz, die Zïchtung der wahren Dysenterieamöbe steht noch aus. Das Experiment ist klar vorgeschrieben: Züchtung derselben in Reincultur, Injection per os, im Cystenstadium, nach vorausgehender Vorbereitung des Darms, eventuell in Verbindung mit Culturen von Bacterium coli commune odẹr Eiterbakterien! Das muss der Zukunft überlassen bleiben.

Capitel VI.

\section{Die Ziichtung der Amöben.}

Die geniale That Koeh's auf dem Gebiete der Bakteriologie, die Isolirung und Reinzüchtung auf festem Nährboden, hat auf dem Felde der Protozoenforschung nicht sogleich ihres gleichen gefunden. Die Amöbenzüchtung hängt in ihren Anfängen innig zusammen mit der Isolirung und Züchtung der Protozoen überhaupt. Verschiedene Anläufe sind dazu gemacht worden. Die ersten Versuche waren primitiver Natur. Auerbach züchtete Amöben, indem er ins Wasser ein kleines Stück thierischen Gewebes legte und diese Mischung, sowie auch Pflanzenaufgüsse, Wasser und Schlamm der Sonne aussetzte. Daneben entwickelten sich Algen und Infusorien. Dann brachte er eine kleine mit destillirtem Wasser verrührte Portion in eine Glasschale uud die Amöben gediehen darin 8 Monate lang. - Leidy erhielt Amöben aus Sümpfen und Gräben. - Cunningham verwendete als Nährboden ein Decoct von sterilisirtem Kuhmist und Pferdemist. Er war der Ansicht, dass die von ihm cultivirten Amöben sich aus Trichomonaden entwickelten. - Grassi, welcher diese Experi-

15-35 $\mu$ misst. Die langgestreclite Form bei Amoeba princeps ist $=440 \mu$, bei Amoeba coli $40 \mu$. Die Fortsätze von Amoeba coli werden gewöhnlich an der Ursprungsstelle wieder eingezogen, bei $A$. princeps laufen die Fortsätze wie eine Welle ringsherum und werden dann erst eingezogen. - Leuckart betont die grosse Aehnlichkeit der Amoeba coli und Amoeba jelaginia, ohne jedoch beide für identisch erklären zu wollen. 
mente nachmachte, wies die vielen Fehler und Unhaltbarkeit dieser Meinung nach. - Gruber versuchte die Züchtung der Amöben in kleinen Glasschalen. - Balsamo Crivelli und Maggi cultivirten auf einem Nährboden ron Eiweiss mit oder ohne Zusatz $1 \%$ boo bis $1 \%$ iger Carbolsäure eine Amöbe, welche sie als Amoeba albuminis bezeichneten. Diese Nührböden hat in neuerer Zeit Rina Monti wieder aufgenommen, indem sie sich einer Lösung von Eiweiss in destillirtem Wasser $(2: 1)$ oder von Eiweiss (2 Th.) in durch $1 \%$ ige Carbolsäure angesäuertem Wasser (1 Th.) bei $14^{\circ} \mathrm{C}$. bediente. Sie züchtete ebenfalls Amoeba albuminis und empfahl diesen Nährboden auch für andere Amöben, z. B. Amoeba vulgaris. Unter anderem schlug Klebs feuchten Torf, Riva mit physiologischer Kochsalzlösung getränkte Kreide vor ete. Eine Reihe von Forschern wurde weiter zu Amöbenzüchtungen angeregt durch die Amöbenbefunde bei der Dysenterie. Kartulis gebrauchte ein sterilisirtes Strohinfus, behufs dessen wurden 20-30 g frisches Stroh 1/4 Stunde lang in 2 Liter Wasser gekocht, darauf filtrirt und sterilisirt. Kruse und Pasquale verwendeten als Culturflüssigkeit Strohaufguss mit Bouillon und Blutserum, reines Nilwasser oder Nilwasser mit Bouillon, Blutserum von Ochsen, ascitische und hydropische Flüssigkeit. Vivaldi nahm ein Decoct ron Heublättern, welches er schwach alkalisch machte, filtrirte und sterilisirte, Dock Fleischbrühe und Reissuppe, Fajardo Strohaufguss, und suchte sie auf der Oherfläche zu züchten; auch Peyrot und Roger bedienten sich des Strohinfuses etc. Welchen Erfolg diese Versuche im Hinblick auf die Amoeba coli Lösch hatten, haben wir im rorigen Capitel bereits erörtert.

Eine scharfsinnige Nethode zur Isolirung ron Infusorien erdachte Ogata, welche verdient, hier näher mitgetheilt zu werden. Er nahm grïnes Wassergras aus einem offenen Canale und liess dasselbe mit Wasser vermiseht in einer grossen Abdampfschale stehen. Dieses Gemisch enthielt bei der Untersuchung verschiedene Arten von Bakterien und Protozoen (Amöben und Infusorien); von letzteren war Polytoma urella sehr zahlreich. Hiervon wurden einige Tropfen in Reagensröhrchen gebracht, die mit folgender Nährlösung gefüllt waren $(50 \mathrm{ccm}$ des unreinen Wassers, in einem Kolben sterilisirt, mit Zusatz von 2,5 pCt. Traubenzucker, dann filtrirt). Nach 5-6 Tagen entwickelten sich zahilreiche Bakterien und Infusorien. Um nun eine bestimmte Art der Ciliaten zu isoliren, tauchte er $10-20 \mathrm{~cm}$ lange, $0,4-0,6 \mathrm{~mm}$ dicke Capillarröhrchen ${ }^{1}$ ) in die sterilisirte Nährlösung, so dass nur ein

1) Auch Danilewsky hat Capillarröhrchen, deren mittlerer Theil platt gedrückt ist, zur Isolirung einzelner Protozoen verwendet. 
leerer Raum von 1--2 cem zurückblieb, dann tauchte er in die bakterien- und infusorienhaltige Flüssigkeit, bis völlige Füllung stattfand. Darauf erfolgte die Zuschmelzung beider Enden in der Gasflamme. Nach 5-30 Minuten, je nach Umständen lassen sich lebhaft sich bewegende Infusorien 2, 3 oder mehr Centimeter von dem ursprünglichen Wasser entfernt in der klaren Nährlösung erkenmen. Die Bakterien gelangen nicht an so entfernte Stellen. Wenn nun die Infusorien mehrere Centimeter von der ursprünglichen Flüssigkeit sich entfernt haben, wird unter dem Mikroskop das Röhrehen an einer bestimmten Stelle markirt und abgebrochen. Das Ende schmilzt man abermals zu. So erzielte $0 \mathrm{~g}$ ata eine Isolirung von Polytoma uvella ohne Bakterien. Noch bessere Resultate hatte er, wenn er eine andere Nährlösung anwandte: $500 \mathrm{ccm}$ Fleischbrïhe aus $250 \mathrm{~g}$ Fleisch, 12,5 g Traubenzucker, 25,0 meist Porphyra vulgaris (Algengemisch, jap. Nori). Dieselbe wird gekocht, neutralisirt, filtrirt und in Reagensgläschen sterilisirt. In diese Nährsubstanz impfte er den infusorienhaltigen Capillarinhalt durch Hineinblasen; so erreichte er eine Reincultur von Infusorien. Entstehende Trübung bereits nach 2-3 Tagen bedeutet Bakterienbeimischung. Polytoma uvella wächst auch auf fester Nährgelatine. Aus Flüssigkeit, in welcher dasselbe reichlich enthalten ist, lạssen sich Plattenculturen machen. Bei Zimmerwärme ist die Colonie auf der Platte nach 1 Woche mit blossem Ange als weisses Pünktchen wahrzunehmen, welches in 2-3 Wochen einen Millimeter gross wird. Dabei wird der Nährboden nicht verflïssigt. Bei Stichculturen in Nährgelatine bemerkt man nach 1 Woche kleine weissliche, isolirte Pünktchen entlang dem Stichcanal. Ebenso züchtete Ogata auch Paramecium aurelia aus Wasser.

Weiter hat 0. Niller über aseptische Protozoenculturen berichtet. Unter Beobachtung aller aseptischen Cautelen in Bezug auf Abhaltung der Luft, Sterilisirung der Hände und Instrumente ging er von dem Grundsatz aus, die Bedingungen, unter welchen diese Lebewesen in der Natur vegetiren, möglichst zu reproduciren. Daher seien Wasser und feuchte Medien die Basis der Culturböden. Er verwendete Hanfaufguss, zur Weissweinfarbe verdünnt, neutralisirte Bouillon (2-4 Th. auf 100 Th. Wasser), 1/2 pCt. Glycerin mit einem Stückchen Sehne (ein cubisches Stück von $1 \mathrm{~mm}$ Grösse in jedem Glase), auch Heuinfus mit $1 / 2$ pCt. Traubenzucker oder $1 / 5$ pCt. Milchzucker. Nach Filtrirungen wurden diese Lösungen in Gläser gebracht, bis zu $1-1 \frac{1}{2} \mathrm{~cm}$ gefüllt und bei Körperwärme gehalten. So erzielte er Culturen von Protozoen, Amöben und Bakterien, stets jedoch zusammen. Miller giebt an, dass er Amöbenculturen $25 \mathrm{mal}$ umgeptlanzt habe. Die 
Arten bezeichnet er nicht speciell. Er hält zum Gedeihen der Amöben die Anwesenheit passender Bakterien für günstig.

Einen sehr bedentungsvollen Fortschritt in der Züchtung der Amöben machten Celli und Fiocea dadurch, dass sie einen festen Nährboden im Sinne der heutigen Bakterienforschung auskundeten. Sie hatten ausser den gewöhnlichen bakteriologischen Nährböden vorher mit ausserordentlicher Mühe alles erdenkliche Naterial als Nährböden benutzt, wie z. B. den Darminhalt der gesunden und an verschiedenen Darmkrankheiten leidenden Menschen, Scheiden- und Mundschleim, Darminhalt von Thieren, Wasser aus Canälen, Sumpferde und Wasser in gesunden und Malariadistricten, Trinkwasser, Thermalwasser, Hüuserstaub ete., - ohne Erfolg. Eine spärliche Cultur trat cin auf alkalinisirten Kartoffeln, auf Eiereiweiss und Ascitesflüssigkeit. Als besten Nährboden aber erkannten sie den Fucus crispus, auf dem sie prachtvolle Culturen erzielten. Derselbe wird 5 proc. wie Agar mit oder ohne Bouillon hergestellt und stets stark alkalisch gemacht. Es ist nicht durehaus nothwendig, ihn zu fiitriren; man kann ihn direct aus den Gefässen in die Petri'schen Schalen giessen. Bei Culturen im hängenden Tropfen muss er stets filtrirt werden. Um diese herzustellen, ist der gewöhnliche Fucus geeigneter und zwar ohne Bouillon und stark alkalisirt (auf $10 \mathrm{ccm}$ Nährboden $1 \mathrm{ccm}$ einer $1 / 10$-Normallösung von Kalilauge, oder 4-5 cem einer gesättigten Lösung kohlensauren Natrons). Bei Anwendung dieses Fucus-Nährbodens gelangten sie zu den Züchtungen der Amöben, welche wir früher in der Tabelle mitgetheilt haben, freilich nie ohne Beimengen ron Bakterien. Um bakterienfreie Culturen zu erlangen, haben sie die versehiedensten Tersuche rergeblich unternommen. Sie versuchten fractionirte Sterilisirungen zu 55-60 eine Stunde lang mit 10 maliger Wiederholung, wiederholte Waschungen und particlle Filtrirungen, Zusatz von Desinficirungsmitteln entweder zu dem Material oder zu dem Nährboden, Amöbeneysten in Gelatineplatten und Isolirung der bakterienfreien Zonen in der Hoffnung auf eine vereinzelte Amöbeneyste, die man dann auf Fueus cultiviren kann, Chemotaxis mit Capillaren und mit den für derartige Versuche gebräuchlichsten Substanzen, Einimpfungen in den Cireulationstrom, in die Leber, in das subcutane Gewebe verschiedener Thiere, in der Hoffnung, dass die Bakterien in ihnen zerstört würden und die Cysten überlebten, Isolirung mit Platinösen unter dem Mikroskop mit einem stark vergrössernden Objectiv und weiter Focaldistanz etc. Zur Isolirung gewisser Species geben Celli und Fiocea folgende Vorsehrift. Gewisse Trink- oder Thermalwässer enthalten nur eine Species. Wenn aber, wie im Boden und 
den Excrementen mehrere vorhanden sind, so wird das Amöbenmaterial in Petri'schen Schalen auf dem oben beschriebenen Fueus cultivirt, dann wartet man, bis der Entwickelungscyclus der Amöben abgelaufen ist und die Cysten gereift sind. Darauf macht man Culturen im hängenden Tropfen und von diesen ist es leicht, eine einzige Species oder Varietät zu erhalten, entweder durch aufeinanderfolgende Uebertragungen, in denen eine Form schliesslich überwiegt und indem man sich die verschiedene Dauer des Entwickelungscyclus und das Reifen der Cysten zu Nutze macht, oder indem man die verschiedenen Formen durch Platinösen isolirt. Aus dem Boden oder den Dejectionen entwickeln sich oft in der ersten Cultur einige Infusorien, die sich jedoch nach 1-3 Uebertragungen nicht mehr reproduciren. So trennt man die Amöben von den Infusorien.

Einen weiteren sehr wichtigen Beitrag zur Amöbenzüchtung lieferte Beyerinck. Auch er benutzte einen festen Nährboden und zwar Agarplatten, auf denen, wie or früher zeigte, das Nitritferment der Ammonsalze leicht gezüchtet werden kann, vorausgesetzt, dass die löslichen organischen, im Agar vorhandenen Körper daraus mittelst destillirten Wassers entfernt und die nothwendigen anorganischen Salze gegenwärtig sind. Zur Herstellung derselben giebt er folgendes Verfahren an: „Filtrirtes, in destillirtem Wasser gelöstes $\Lambda$ gar wird in einem Erlenmeyer'schen Kolben in nicht zu dicker Schicht zum Erstarren gebraeht, mit destillirtem Wasser übergossen und ruhig sich selbst überlassen. Die löslichen Körper diffundiren in das Wasser hinüber, und in diesem entsteht gewöhnlich eine spontane Bakteriencultur. Nach einigen Tagen wird das Wasser abgegossen, und dieses wird mehrmals wiederholt. Nach 1-2 Wochen, abhängig von der Dicke der auszulaugenden Schicht, sind die löslichen organischen Substanzen genügend aus dem Agar entfernt, um das Wachsthum der Nitritfermente zu ermöglichen. Die Mlasse wird mit dem zur Nitritbildung gecigneten Salzgemisch sowie mit einem präcipitirten Calciumcarbonat versetzt und damit aufs Neue gekocht, wodurch die einzelnen anhängenden Bakterien getödtet werden und nach dem Uebergiessen in cine Glasdose ein sich für das Wachsthum des Nitritfermentes ganz ausgezeichnet eignender steriler Culturboden erhalten wird. Von den zur Nitritbildung vorzuschlagenden Ammonsalzen empfiehlt Beyerinck ganz besonders das Phosphorsal\% $\left(\mathrm{NH}_{4} \mathrm{NaHPo}^{4}+4 \mathrm{H}_{2} \mathrm{O}\right)$, welehes beim Kochen das Agar nieht angreift und deshalb nicht zur Neubildung löslieher organischer Producte aus dem Agar Anlass giebt. Bei Phosphorsalz konnte bis 0,5 pCt. zugesetzt werden, ehe eine Verminderung des Oxydationsvorganges bemerkbar wurde, jedoch ist ein 
geringerer Gchalt $(0,2 \mathrm{pCt}$.) vorzuziehen. Neben dem Ammonsalze soll ca. 0,05 pCt. Chlorkalium zugesetzt werden. Durch die Kreide bleibt die Reaction neutral oder schwach alkalisch." Nach Uebergiessen der Agarplatten mit in Wasser aufgeweichter Gartenerde (aus der Nähe von Delft) entwickelte sich nebenbei eine Erdamöbe, von ihm Amoeba nitrophila genannt, wegen ihres gemeinsamen Vorkommens mit Nitritfermenten. Sobald nach fünf oder mehr Tagen die Nitritfermentcolonien durch das locale Durchsichtigwerden des Bodens sich markiren, sieht man mit der Lupe körnige Stellen auf der glänzenden Oberfläche der Agarplatte, welche ihren Glanz verloren haben und aus Ansammlungen ron Amoeba nitrophila bestehen. Durch Ausdehnung dieser Punkte bedeckt sich schliesslich die ganze Platte mit Amöben. Die Amöben kommen auch zur Entwickelung, wenn zufällig keine Nitrification eintritt, und Beyerinck hält deshalb die ausgewaschenen Agarplatten auch für die Cultur anderer Amöben geeignet. Sodann züchtete er aus Trauben, "welche durch Wespen angenagt und in spontane Gährung gerathen waren," auf einem Nährboden von Malzextractgelatine neben Sacharomyees apiculatus und Essigbakterien eine Amöbe, welche er Amoeba zymophila nannte. Nach Impfstrichen mit der Gährungsmasse krochen an bestimmten Stellen die Amöben in Scharen hervor und brachten auf der Platte stellenweise einen schleierartigen Belag hervor. Von diesem Schleier impfte er eine neue Malzextract-Gelatineplatte; es entstanden durch wiederholte Ueberpflanzungen Amöben nebst Essigbakterien und Apiculatushefe. Diese Culturreihe Amöben + Apiculatus und Amöben + Essigbakterien wie Amöben + Apiculatus + Essigbakterien lässt sich auch auf Fleischgelatine und Fleiscliagar in Reagensröhren fortführen, doch ist Malzextractgelatine vorzuziehen. Die Entwickelung geht einher mit starker Verflüssigung des Nährbodens. Es gelang jedoch Beyerinck nicht, ebenso wenig wie den italienischen Forschern, die Amöben ohne die Gegenwart von Bakterien und Hefezellen zu zïchten. Nach seiner Ansicht sind dieselben zu ihrer Existenz nothwendig. Er hat die Cultur von Amoeba zymophila über ein Jahr und mehr auf diese Weise fortgeführt im Laboratorium. Herr Beyerinck war so freundlich, mir im Juli d. J. eine Cultur von Apiculatushefe und Amoeba zymophila in einem Reagensröhrehen zuzusenden; ich muss seine Beobachtungen vollständig bestätigen, auch mir ist es gelungen, die Culturen in der angegebenen Weise fortzufülıren.

Im Anschluss an die Beyerinck'schen Resultate sei mitgetheilt, dass Gorini die Amoeba zymophila mit Apiculatushefe auch auf 
Kartoffeln ohne Alkalinisirung, gelben wie rosafarbenen, alten wie jungen weiterzüchtete. Dasselbe gelang mir auf Kürbisscheiben.

Einen weiteren interessanten Beitrag zur Frage der Züchtung von Amöben auf festem Nährboden hat Schardinger geliefert. Er ging zurück auf den schon früher angewendeten Heu- und Strohaufguss, dem er kohlensaures Natron und Agar zusetzte. Nach seiner zweiten Publication aus den letzten Jahren ist seine specielle Zusammensetzung folgende: ca. $30 \mathrm{~g}$ Heu werden in einem Liter Wasser suspendirt, nach Zusatz von $1-1,5 \mathrm{~g}$ gepulvertem Kalkhydrat wird kräftig umgeschüttelt und die Mischung 24-36 Stunden in den Brütofen gestellt. In der vom verwendeten Material durch Filtration befreiten Flüssigkeit wird der Kalk durch Phosphorsäure gefällt, event. mit Fleischwasser (bereitet in der gewöhnlichen Weise ohne Pepton und Kochsalz) zu gleichen Theilen vermengt, mit Soda alkalisirt und unter Zugabe von $1-11 / 2$ pCt. Agar wie gewöhnlich weiter rerarbeitet. Ein höherer Gehalt von Agar empfiehlt sich nicht, da zu wenig Condensationswasser entstcht, und ein möglichst hoher Feuchtigkeitsgehalt für die Cultur der Protozoen wesentlich erscheint. Schardinger impfte eine Oese des Kothes von einem an fieberhafter Diarrhoe leidenden Mannes in das Condensationswasser von Heuagar, schon am nächsten Tage zeigten sich einige Amöben, ähnlich der Amoeba coli, die er seit Jahren weiterzüchtet und die wịr früher bereits beschrieben haben. Schardinger's jetziger Züchtungsmodus ist folgender. Er überträgt das Aussaatmatcrial direct in das Condensationswasser seines Nährbodens und von drei zu drei Tagen nimmt er eine Uebcrimpfung von Condensationswasser zu Condensationswasser vor. Interessant ist dabei die Beobachtung des Aufwärtskriechens in frisch angelegten Culturen. Der Vormarsch der Amöben geschieht meistens in der ganzen Breite der schrägen Agarfläche und lässt sich Tag für Tag verfolgen. Die von den Amöben bedeckte Fläche sieht matt, wie bestäubt aus, die amöbenfreie glänzend. Am 3.-4. Tage sind die Amöben gewöhnlich bis an das Ende des Agars vorgedrungen, und die hier befindlichen sind frei von Amöben, aber nicht fortzüchtbar. Diese Amöben haben ein kümmerliches Aussehen, sind im hängenden Tropfen weniger beweglich nnd kaum halb so gross, als die mit den Bakterien gemeinsam gewachsenen ${ }^{1}$ ). Auch er kommt

1) Celli und Fiocea erwähnen Involutionsformen bei ihren Culturen ,aus noch nicht gut definirten Gründen", Amöbencysten, die auf das feinste granulirt sind, mehr oder weniger rundlich, mit stellenweise unregelmässiger wie unterbrochener Contour. 
zu der Ansicht, dass die Bakterien zum Gedeihen der Amöben nothwendig sind. Bei der Weiterzüchtung ist ein zeitweiliger Wechsel in den Nährböden - Henagar, Heufleischwasseragar - empfehlenswerth.

Weiter haben neuerdings II. Nencki, N. Sieber und W. Wyznikiewicz in der Berliner klinischen Wochenschrift bei Gelegenheit von Untersuchungen über den Erreger der Rinderpest und seiner Züchtung günstige Nährsubstrate für Flagellaten und Amöben gefunden. Sie bedienten sich hauptsïchlich zweier Culturböden, eines Nucinagar und eines Nährbodens von Agar mit anorganischen Salzen. Der erstere wird nach ihrer Vorschrift folgendermassen hergestellt: $1-2 \mathrm{~kg}$ frisch aus dem Schlachthause entnommener Submaxillardrüsen vom Rind werden herauspräparirt, fein zerhackt, mit dem 5 fachen Gewicht destillirten Wassers übergossen und unter häufigem Umrühren 20 bis 24 Stunden in der Kälte stehen gelassen. Darauf filtrirt man durch Fliesspapier und filtrirt das dickliche Filtrat sofort durch Chamberlandkerzen in sterile Gefässe. Die Kerzen sind vorher auf ihre Durchlässigkeit zu prüfen. Sie dürfen keine Bakterien durehlassen und andererseits nicht zu dick in der Wandung sein. Durch Fliesspapier lässt sich der wässrige Auszug der Speicheldrüsen gut filtriren. Aus dem neutral reagirenden Filtrate kann durch Zusat\% von so viel verdünnter Salzsäure, dass die Lösıng 1,5 pro Mille $\mathrm{HCl}$ enthält, das Mucin als schleimige Masse abgeschieden werden. Das gefällte und mit Wasser ausgewasehene Mucin kann von Neuem in Alkali gelöst und durch Zusatz von Agar zur Herstellung eines festen Nälírbodens - Mucinagar - verwendet werden. Die durch Fliesspapier filtrirte Mucinlösung trübt sich beim Kochen, wobei sich etwas Eiweiss abseheidet. Setzt man jedoch zu dem Filtrate soviel Kali- oder Natronhydrat hinzu, dass die Lösung $0,3-0,5$ pro Mille Alkali enthält, so bleibt die Lösung auch beim Kochen klar und kann auf diese Weise sterilisirt werden. Das Muein wird in sterile Röhrehen gegossen, andererseits kann es zu festen Nährböden zugefügt werden. - Der andere Culturboden: „Agar mit anorganischen Salzen" ist folgendermassen zusammengesetzt: $10-15 \mathrm{~g}$ Agar werden zunächst durch 2-3maliges Aufgiessen von destillirtem Wasser ausgelaugt, hierauf in einem Liter sehr heissen Wassers gelöst. Der Lösung werden hinzugefügt: $0,5 \mathrm{~g}$ phosphorsaures Kalium, $1 \mathrm{~g}$ calcinirte Soda, 2,5 g neutrales schwefelsaures Ammon und 5-10 g Kochsalz. Die Lösung wird filtrirt und im Autoclaven sterilisirt. Bei der Sterilisation verflüchtigt sich ein Theil des Ammoniaks: Dieser Umstand macht gerade den Nährboden für die Amöbencultur geeignet. Wenn die ge- 
nannten Autoren sofort nach dem Tode rinderpestkranker Thiere kleine Portionen von Erosionen an den Lippen oder Zunge, Eiterpfröpfe aus den Peyer'schen Plaques, Magen-, Darmschleimhaut auf anorganischen Agar übcrtrugen, und bei $37,5 \mathrm{C}$. stehen liessen, so sieht man meistens schon nach 16-24 Stunden uin den trüben Rand der hineingelegten Stücke mikroskopisch ausser Bakterien auch Amöben. Von hier auf flüssiges Mucin in Petrischalen überimpft, werden sie 18-24 Stunden bei Brït- und dann bei Stubentempcratur stehen gelassen. Empfehlenswerth ist es, jede neue Ueberimplung nur kurze Zeit bei Brut- und dann bei Zimmertemperatur zu belassen. Rathsam ist es auch, sic von Zeit zu Zeit auf anorganischen Agar zu übertragen. Auf Mucin und Agar halten sich solche Culturen 2 bis 3 Monate lang. Selbst wenn Austrocknung stattgefunden hat, ist es nur nothwendig, frische Mucinlösung zuzusetzen und kurze Zeit auf 37,5 C. zu lassen, um die eneystirten Amöben wieder beweglich zu machen. Sie sind bis zu 20 Generationen gezüchtet worden, jedoch gestehen diese Autoren auch ein, nie ohne Bakterien, wie ihre Vorgänger auf diesem Gebiete. Die Grösse der Amöbon schwankte zwischen 2-14 $\mu$; auf dünnflüssigem Nährboden (1 proc. Agar oder Mucin) sind dic Pseudopodienbewegungen viel lebhafter; sie lassen es unentschieden, ob sie es mit einer oder mehreren Species zu thun haben. Auf Heuinfus und Heuagar wuchsen sie schlecht. Für Wiederkäuer waren sie nicht pathogen, wie die Injectionen von Amöbenculturen in ca. 20 Versuchen bei Kälbern und Ziegen lehrten.

Uẻberblicken wir noch cinmal die erwähnten Mittheilungen, so sehen wir, dass eine ganze Reihe von Amöbenculturböden vorliegen. Dennoch ist dieses Problem nicht zum Abschluss gebracht. Im Laufe der Jahre hat sich die Amöbologie zu bestimmten Fragen zugespitzt. Fragen über die flüssigen und festen Nährböden, die Reaction der Cultursubstrate, über die Nothwendigkeit von Bakterien auf den Culturböden, über die absolute Reinzüchtung etc. sind in den Vordergrund des Interesses getreten. Besonders haben in neueren Arbeiten Casagrandi und Barbagallo sowie Frosch sich mit diesen strittigen Punkten beschäftigt. Es handelt sich darum, was gilt heute als gesicherter Standpunkt in dieser Angelegenheit und was ist Sache weiterer Forschung?

Darüber herrscht kein Zweifel mehr, dass heut zu Tage eine ganze Anzahl von Nährböden existiren, auf denen sich Amöben künstlich züchten lassen. Ausser den bereits genannten führt Frosch noch an: Kohlrüben, Runkelrübenschalen, pflanzliche Abkochungen und Lösungen aller Art, besonders Asparagin- und Glykogenlösungen ete. 
Sein Agarnährboden ist folgendermassen zusammengesetzt: $1 / 2 \mathrm{~g}$ Agar, $90 \mathrm{~g}$ Jueitungswasser, $10 \mathrm{~g}$ gewöhnliche alkalische Bouillon.

Casagrandi und Barbagallo züchteten unter anderen aus Bierhefe auf Gipsblöcken Amoeba guttula und spinosa. - Riva will auf Kreide mit physiologischer Kochsalzlösung getränkt Amöben und Trichomonaden cultivirt haben.

Welchen Werth haben diese Nährmaterialien und wie entsprechen sie den strengen Anforderungen der Wissenschaft?

Die flüssigen Nährböden, die Infusionen und Decocte sind im Allgemeinen von geringem Werth, wegen der sehr schwierigen Sterilisation selbst bei längerer Dauer. Dazu kommt das unreine Impfmaterial, das stets Mikroorganismen versehiedener Art enthält. Es darf dabei nicht Wunder nehmen, wenn in diesen flüssigen Medien ausser den Amöben sich nebenbei Ciliaten, Flagellaten, Faden-, Hefepilze und Bakterien entwickeln. Bei noch so oft wiederholter Uebertragung auf neue Nährböden ist schliesslich keine Isolirung möglich. Viel vortheilhafter sind dagegen feste Nährböden. Dic Eiweissnährböden geben im Allgemeinen günstige Resultate, ebenso die mit Infusen von Pflanzenmaterialien etc. festgemachten Agarnährböden : Heuinfusagar, Strohinfusagar, Mlucinagar etc. Der Agarnährböden bedienten sich auch Piccardi, Perroneito und Bosso. Freilich ist dabei eine gute Sterilisirung nothwendig, um Unreinlichkeit von Seiten des Materials ganz auszuschliessen. Ich empfeble einen Flachsinfusagamährboden, auf den ich kam, weil ich in einem Graben, in dem Flachs geröthet wurde, sehr reichlich Amoeba spinosa vertreten faud. Seine Zubereitung ist diese: $25 \mathrm{~g}$ Flachsstengel lässt man mit einem Liter Wasser gemischt 48 Stunden stehen, dieser Auszug wird filtrirt, dazu 1 pCt. Agar und kohlensaures Natron bis zur alkalischen Reaction, schliesslich 1 Stunde Sterilisation. Darauf habe ich mehrfach reichliche Culturen von Amoeba spinosa, oblonga ete. erzielt. - Sehr geeignet zu Amöbenzüchtungen ist der von Celli und Fiocea empfohlene Fucus Crispus; Casagrandi, Barbagallo und viele andere Amöbenforseher haben seine guten Eigenschaften bestätigt gefunden. Mit Hülfe dessen sei es bei Geduld möglich, Amöben schliesslich zu isoliren. Freilich haben alle diesc Cultursubstrate, auch der letzte, den Uebelstand, dass eine Reincultur ohne Bakterien bisher nicht möglich gewesen ist. Immẹr waren die isolirten Amöben mit Bakterien vermengt. Eine Reihe von Forschern sind daher der Meinung geworden, dass die Bakterien zum Gedeihen der Amöben nothwendig sind. Andere wiederum glauben, dass der Nährboden als solcher Nährstoffe liefere für die Erhaltung und Vermehrung der Amöben. Besonders 
hat Beyerinck die Mcinung vertreten, dass zum Gedeihen seiner Amoeba zymophila die Anwesenheit der Apiculatushefe durchaus nothwendig ist. Auch Frosch, der sehr scharfsinnige Untersuchungen in dieser Hinsicht angestellt hat, ist zu einem ähnlichen Resultat gekommen. Es giebt 2 Wege, diese schwierige Frage zu entscheiden, entweder einen Nährboden herzustellen, auf dem sich die mitausgesäeten Bakterien überhaupt nicht lebend crhalten können, oder die Amöbenaussaat von lebenden Bakterien zu befreien. Celli und Fiocca haben versucht durch starke Alkalescenz ihres Fucus Crispus die Vermehrung der Bakterien möglichst zu beschränken. In gewissem Sinne ist ihnen dies gelungen, doch nicht ganz. Trotz aller erdenklichen Manipulationen, die wir früher mittheilten, waren bei den Culturen stets Bakterien zu constatiren. Den zweiten Weg hat Frosch eingeschlagen. Er züchtete aus Gartenerde eine Amöbe, die wir vorher beschrieben; diese bildet Cysten, weiche er bei seinen Versuchen benutzte. Er fand ein Mittel, gewisse nicht sporenbildende Bakterien abzutödten durch 20 proc. Lösung der wasserfreien Soda (72-74 stündige Einwirkung bei Zimmertemperatur). Dabei erhielten sich die widerstandsfähigeren Cysten. Vorversuche hatten gezeigt, dass sich die betreffende Amöbenspecies in üppiger Weise auf gewöhnlichem, oberflächlich feuchtem, frischem Laboratoriumsagar mit Hilfe einer besonderen Bakteriencolonie entwickelten. Diese Bakterienart ist ein plumpes, an den Enden abgerundetes, unbewegliches Kurzstäbchen, welches keine Sporen bildet und dessen Vegetation auf Agar in Gestalt eines saftigen weisslichen Rasens erfolgt. Auf dem mit dieser bestimmten Erdbakterienart verimpften Agar keimen dann die Cysten zu Amöben aus, was auf keinem der anderen Nährboden geschah. Auch die Stoffwechselproducte oder die durch sie bewirkten chemischen Veränderungen der festen und flüssigen Nährböden liessen die Cysten nicht keimen, ebenso die abgetödteten Bakterien nicht. Frosch kommt deshalb auch zu der Ansicht, dass seine Amöbe bestimmter lebender Elemente zum Gedeihen benöthigt, betont jedoch ausdrücklich, dass er aus diesem einen Fall nicht allgemeine Schlüsse ziehen will.

Casagrandi und Barbagallo wollen von einer solchen Amöben-Bakterien-Symbiose nichts wissen. Sie erkennen solche Beziehungen zwischen einander nicht an. Das Fressen der Amöben von Bakterien und Hefe habe keine besondere Bedeutung, es sei eine allgemeine phagocytäre Eigenschaft derselben und auf gleiche Stufe zu setzen mit dem Fressen von Detritus überhaupt. Bei entsprechend alkalisch gemachtem Fucus könne man bei einiger Geduld die Bakterien 
auch von den Amöben trennen und diese letzteren machten trotzdem ihren Entwicklungseyklus auf den Culturen durch. Sie erinnern auch an die wiederholt bestätigte Thatsache, dass Leberabscesseiter bei der Dysenterie bakterienfrei befunden wurde - ein Beweis, dass die Amöben Bakterien zur Existenz nicht nöthig haben. Bemerkenswerth ist allerdings folgendes Factum. Schardinger berichtet, wie erwähnt, von dem Aufwärtskriechen der Amöben auf der schrägen Culturfläche. Er sagt wörtlich in seiner letzten Publication: „Am 3.-4. Tage sind die Amöben bis an das Ende des Agars gelangt und die hier befindlichen sind frei von Bakterien, aber nicht fortzüchtbar, wenigstens nicht auf den angegebenen Nährböden. Das Freisein von Bakterien (also eine wirkliche Reincultur) zeigt sich 1. durch das Ausbleiben jeglichen Wachsthums auf den damit geimpften frischen Nährböden, fest oder flüssig, bei Brut- oder Zimmertemperatur, 2. am Fehlen der Bakterien in gefürbten Deckglaspräparaten. Diese Amöben sehen kümmerlich aus, zeigen im hängenden Tropfen eine bedeutend geringere Beweglichkeit und kaum die Hälfte der Grösse gegeuüber den gemeinsam mit Bakterien gewachsenen." Daraus wäre auf den ersten Blick zu folgern, dass diesen Etwas zu ihrem Gedeihen fehlt. Ich bin augenblicklich damit beschäftigt, ob nicht dieser äussersten Avantgarde der Amöben auf schrägen Nährböden ein Surrogat für die fehlenden Bakterien in Gestalt von Blutkörperchen, Stärkekörnchen etc., welche auf diesen Theil des Nährbodens gebracht werden, zu schaffen ist. Jedenfalls bedarf es noch weiterer Untersuchungen, ehe diese Frage der Symbiose endgültig gelöst ist. Vielleicht liegt auch hier die Wahrheit in der Mitte. Die einzelnen Amöbenarten werden höchstwahrseheinlich versehieden zusammengesetzte Nährböden, auch solche mit organischen Bestandtheilen gemischte, nöthig haben, wie dies bei den versehiedenen Bakterienspecies der Fall ist.

Mehr Klarheit ist bereits geschafft in der Frage über die Reaction des Culturmediums. Im Allgemeinen passt für die Amöbeneulturen ein mässig alkalisches Substrat, es kam auch neutral sein. Stark alkalische und saure Medien sind durchschnittlich sehädlich, obwohl auch sicher Ausnahmefälle vorkommen. Es lassen sich Amöben von alkalischen Substraten allmälig auch auf saure überpflanzen durch Anpassung. Beyerinck erinnert an die saure Reaction von gährenden Trauben und Fruchtsäften. Er selbst züchtete seine Amoeba zymophila aus einer gährenden Weintraube. Er citirt ferner Lindner, welcher mittheilt: "Ausser auf Gipsblöcken konnte Verf. ein massenhaftes Auftreten von Amöben in einem stark gährenden Fruchtsafte, 
der einige Tage lang in einem offenen Gefässe im Zimmer gestanden hatte, constatiren. Der Saft war ziemlich stark sauer. Die Amöben zeigten sich äusserst lebendig und trieben auch hier ihre Jagd auf Hefezellen." - Schliesslich sei bemerkt, dass auch Amoeba coli einigemal in sauer reagirenden Dysenteriestühlen lebend gefunden wurde. - Casagrandi und Barbagallo machen schliesslich noch beherzigenswerthe Mittheilungen über die Cultivirbark eit der Amöben. Wie sie hervorheben, lassen sich nur die Amöben auf den Culturböden züchten, welche ein freies Leben führen, eine contractile Vaeuole und einkernige Cysten haben. Nicht züchtbar dagegen sind die parasitären Amöben, welche der contractilen Varicuole entbehren und bei denen mehrkernige Cysten vorkommen, Eigenschaften, wie sie den niedrigeren parasitären Protozoen eigenthümlich sind. Wenn man aus dysenterischen Stühlen Materie auf den Culturboden bringt, so runden sich die beweglichen Amöben ab und zerfallen allmälig. Die encystirten Formen degeneriren, bersten und verschwinden nach 8 bis 10 Stunden. Dasselbe beobachteten sie, wenn sie Excremente von Blatta, welche die Amoeba blattarum (Bütschli) im encystirten und nicht encystirten Zustande enthielten - grosse Amöben von genau bestimmten Eigenschaften -, auf die Nährböden brachten. Auch sie gingen bald unter.

Capitel VII.

\section{Technik der Untersuchung.}

Histologische und bakteriologische Untersuchungen haben es meist mit todtem Material zu thun. Anders bei den Protozoenuntersuchungen. Hier ist die Beobachtung am lebenden frischen Material wegen der Bewegungsvorgänge, des complicirten Lebenslaufes etc. unerlässlich. Ani vortheilhaftesten geschieht die Untersuchung in demselben Medium, in dem die Amöbe lebt, ohne Zusatz fremder chemischer Flüssigkeiten, da diese Organismen sehr empfindlich gegen jede chemische und physikalische Veränderung sind. Als Ersatz der Flüssigkeit kann eine physiologische Kochsalzlösung dienen. Das Deckglas wird am besten durch Glassplitter oder.Umschmelzen der 4 Ecken hochgehalten, um eine Quetschung der zarten Gebilde zu verhüten. Sehr empfehlens- 
werth sind 4 kleine Wachsfüsschen; durch Druck auf dieselben kann man die Flüssigkeit so corrigiren, dass die beweglicheren Formen sich innerhalb des Gesichtsfeldes leichter fixiren lassen. Ein Vaselinoder Wachsrand verhindert die Verdunstung der Flïssigkeit. Zur gewöhnlichen Untersuchung genügen Trockenlinsen, zum Studium der feineren Amöbenstructur ist Oelimmersion nothwendig. Entwickelungsvorgänge unter dem Deckglas oder im hängenden Tropfen müssen im Thermostaten verfolgt werden.

Was die Färbung der Amöben anbelangt, so haben sich charakteristische Farbenreactionen, welche in der Bakteriologie so hervorragende Dienste leisten, bisher nicht aufstellen lassen. Je nachdem verwendet man dazu die Anilinfarben etc.

Die Färbungen am lebenden Material sind nicht zu rathen, da meist Schrumpfungen oder Absterben der zarten Organismen dadurch hervorgerufen werden, ఒ. B. in Nethylenblaulösungen. Will man dennoch durch eine schwache Färbung die Beobachtung sich erleichtern, so eignen sich dazu Eosin und Bismarckbraun, gelöst in Humor aqueus, Amnionwasser.

Zur Erzielung gefärbter Dauerpräparate aus flüssigen Medien ist vorheriges Fixiren nothwendig. Dazu eignen sich Osmiumsäure-, Sublimat-, Goldchloridlösung etc. Sehr zu empfehlen ist in erster Linie concentrirte Sublimatlösnng. Schaudinn beobachtete bei Anfertigung von Dauerpräparaten der Leydenia gemmipara folgendes Verfahren, das sich gut bewährt hat: Deckgläser mit der Amöben enthaltenden frischen Ascitesflüssigkeit bestrichen, werden sofort in eine heisse Mischung von 2 Th. concentrirt wässriger Sublimatlösung mit 1 Th. Alcohol absolutus gethan und darauf mit 63 pCt. jodhaltigem Alkohol ausgewaschen, mit Grenacher'schem Hämatoxylin oder Eisenhämatoxylin nach Benda-Heidenhain gefärbt und in Canadabalsam eingebettet. Allerdings gelingt es nicht, die Pseudopodien ganz in der Ursprünglichkeit zu erhalten. Es findet stets bei der Berührung mit diesem Gemisch eine Contraction statt. Die Fixirung unter dem Deckglas scheitert meist daran, dass bei der Einbringung der Fixirungsflüssigkeit das Eiwciss am Rande gerinnt und ein schnelles Vordringen derselben vereitelt. - Schardinger macht über sein Verfahren folgende Angabe: Ilan bringt einen Tropfen sterilen Wassers auf ein reines Deckglas und beschickt diesen mit einer Platinösc amöbenhaltigen Culturmaterials, welche der schrägen Agarfläche entnommen ist. Das lufttrockene Präparat kommt 2-3 Minuten in ein Gemisch von gleichern Theile Alkoholäther und wird nach neuerlicher Trocknung in einer wässerigen Jösung von Methylenblau gefärbt. So 
erhält man schöne Amöbenpräparate, in denen zuweilen auch die verschiedenen Bewegungsphasen und Theilungsvorgänge fixirt sind.

Zur Untersuchung der Dysenterieamöben speciell seien noch einige Notizen gemacht. Die Stuhlentleerungen müssen ganz frisch, in ungefärbtem Zustand, auf das Objectglas gebracht werden. Behufs dessen sind, sie in einem der Körpertemperatur entsprechend erwärmten sterilen Gefäss aufzufangen. Ton düunen Dejectionen bringt man einfawh cinen Tropfen auf den Objectträger. Zu bevorzugen sind dabei blutiggefärbte Schleimflocken, auch gelblich gefärbte Flocken und froschlaichartige Klïmpchen. Consistenter Stuhl wird mit erwärmter Kochsalzlösung aufgewässert. Fajardo gebraucht zur Verdünnung lauwarmes Wasser sowie eine schwache Chlornatrium- oder schwefligsaure Natronlösung. Von geformten Massen streicht man den Schleim ab. Indicirt sind fortlaufende Untersuchungen in gegewissen Zeiträumen, da ein oder wenige Präparate trügen. Bei ca. 500 facher Vergrösserung sieht man in den Präparaten unter zahlreichen rothen und weissen Blutkörperchen Epithelien, Detritus, Massen von Bakterien und Nahrungsresten etc., sich durch Grösse und Bewegung auszeichnende glänzend erscheinende Amöben von den Eigenschaften, wie sie bei der Beschreibung der Amoeba coli Loesch vorher geschildert wurden. Nicht selten bemerkt man im Inneren derselben rothe Blutkörperchen, Amylumkörnchen, Bakterien etc., welche als Nahrung aufgenommen sind; bemerkt sei, dass sie auch Trichomonaden und lebende llegastomen rerschlingen können. In die Augen fällt das Aussenden und Wiedereinziehen stumpfer, homogener Fortsätze ${ }^{1}$ ), seltener verlaufen die hyalin herausquellenden Iassen wellenartig um den Körper herum. Eine Theilung im Darm ist anzunehmen, aber noch nicht beobachtet worden. Freilich nicht lange lässt sich dieses Spiel beobachten. Die Bewegungen lassen allmälig nach; die Parasiten ziehen sich wieder zusammen, der Unterschied zwischen Ecto- und Entoplasma verwischt sich. Bei gewöhnlicher Zinumertemperatur verliert sich das amöboide Stadium nach wenigen Stunden, ausnahmsweise kann die Beweglichkeit in heissen Sommer-

1) Instructiv für den angehenden Amöbenforscher ist das Beobachten von Struhamöben. Diese kann man sich sehr einfach verschaffen dadurch, dass man Stroh mit Wasser in einem mit durchlöchertem Papier bedeckten Glase stehen lässt. Bereits am dritten Tage entwickeln sich dann Amöben. Der an der Oberfläche sich bildende Schleim auf den Objectträger gebracht, zeigt sich sehr lebhaft bewegende und lobäre Fortsätze ausstreckende Amöben mit Kern und Vacuolen. Der Unterschied von Leucocyten wird klar, wenn man Strohamöben mit Eiter oder Wundsecret vermischt bei gleicher Temperatur. 
tagen 7-24 Stunden anhalten. Fajardo konnte bei Zimmertemperatur lebende Amöben in einem frischen Präparat aus einem Leberabscess noch nach 30 Stunden constatiren. Durch zeitweises gelindes Erwärmen des Objectträgers wird die bereits erloschene Beweglichkeit wieder in Thätigkeit versetzt. Dies kann mehrere Male hintercinander geschehen. Interessant ist auch dieser Vorgang. Wenn man den Objectträger mit.beweglichen Amöben schnell durch eine Flamme hin und herbewegt, so crkennt man, wie die Amöben sich abgerundet habien, um alsbald wieder in die amöboide Bewegung zu gerathen. Zur dauernden Beobachtung eignet sich am meisten der Thermostat. Er birgt den Vortheil lebendigerer Beweglichkeit der Parasiten. Auf diese Weise ist es auch möglich, sie länger vor dem Absterben zu bewahren; aber durchschnittlich nach 24 Stunden pflegt alles Leben erloschen zu sein.

Die zur Ruhe gekommene Amocba coli degenerirt nach und nach, indem sie entweder homogen, fettähnlich glänzend wird oder körnig zerfällt. Mlikroskopisch unter gewöhnlichem Deckglaspräparat kann man sie nicht länger als zwei Tage auffinden. Wenn man einen dysenterischen Stuhl erst am zweiten, dritten Tage untersucht, wird man auf eine sichere Diagnose nicht mehr rechnen können. Anders verhält es sich mit den encystirten Formen, welche im Allgemeinen kleiner $(10-12 \mu)$, von runder Gestalt und schärfer, zuweilen doppeltcontourirt sind. Diese Dauerzellen sind länger widerstandsfähig. Noch nach Verlauf von drei Wochen hat man diese unter dem Deckglas beobachtet. Quincke, welcher den Stuhl länger aufhewahrte, konnte sie nach einem Monat nicht mehr wahrnehmen.

Aehnlich gestaltet sich die mikroskopische Untersuchung des Eiters dysenterischer Jeber-, Lungenabscesse etc. Ein Tröpfchen des Eiters wird frisch auf das Deckglas gebracht. Ein geübtes Auge vermag die beweglichen Amöben unter den Leukocyten deutlich zu unterscheiden; auch in den Abscesswandungen sind sie nachgewiesen. Der Sicherheit halber sind auch hier stets mehrere Präparate anzufertigen, da nicht jeder Tropfen Eiter Amöben in sich schliesst.

Zum Nachweis der Amöben im Gewebe, in Darmschnitten eignen sich verschiedene Farbstoffe. IIethylenblau-, Gentianaviolett-, Hämatoxylinlösung, Eosin etc. Eine specifisches tintoriclles Verfahren yiebt es nicht. In den Schnitten erscheinen die Amöben meist rundlich oder oval. Fajardo machte die Schnitte mit dem Schanz'schen Mlicrotom, nachdem die Stückchen in Alkohol absolutus oder Chloroformbehandlung in Paraffin eingebettet waren. Er färbte mit saurer Häematoxylinlösung. Councilmann und Lafleur härteten die Ge- 
websschnitte in Flemming'scher Lösung und färbte mit Carmin, Methylenblau oder Hämatoxylin. Versehiedene Forscher, besonders Kartulis, haben an Leichen von an Dysenterie Verstorbenen sowie von inficirten Katzen die pathologisch-anatomischen Verhältnisse und die Lagerung der Amöben 'in den einzelnen Darmschichten studirt. Bereits früher haben wir Kartulis' Ansicht über die Genese der Amöbengeschwüre angeführt. Abgesehen von dem histologischen Befund sind in dem entzündlich katarrhalischen Stadium der Ruhr, das selten beobachtet wird, die Amöben auf der Oberfläche vorhanden, zuweilen findet man sie bis in die intraglandulären Räume vorgedrungen. Wichtiger sind die Verhältnisse bei dem Verschwärungsprocess, welche Kartulis in seiner Monographie über die Dysenterie durch verschiedene Abbildungen näher veranschanlieht hat. Hier liegen. sie mehr oder weniger tiefer, je nachdem der geschwürige Process in der Tiefe vorgesehritten ist. Hauptsächlich finden sie sich in der Submucosa. Auch in den Capillaren und den Wandungen sind sie nachgewiesen. Nach Kartulis' Beschreibung kommen in der Submucosa neben den Amöben entzündliche Vorgänge vor, auf welche man sonst bei Versehwärungen anderer Natur nicht stösst. Grosse Zellen von Amöbengrösse, rundlicher Form, einfacher Contour, kleinem Kern werden wahrgenommen. Sie unterscheiden sich aber von den Parasiten dadurch, dass ihnen die Vaeuolen fehlen, sie die Anilinfarben schlecht annehmen, ihr Kern viel kleiner ist ete. Er fasst sie als Bindegewebszellen auf. Bei chronischer Dysenterie lagern die Amöben meist am Rande der ausgedehnten, in der Basis verdickten Geschwüre. Sie nehmen die Anilinfarben nur schwierig an und bergen im Innern sich stark mit Anilinfarben tingirende Gebilde, die an plumpe dicke Bacillen erinnern. Bei den diphtheritischen und nekrotischen Processen der Dickdarmschleimhaut sind Amöben in der Submueosa nur spärlich vorhanden, dagegen massenhaft in den Geschwüren Schizomyceten vertreten, von denen besonders Streptokokken, Bacterium coli, Staphyloecus pyogenes albus und aureus etc. dominiren. 
Capitel VIII.

\section{Literatur.}

\section{a) Allgemeine Literatur über Amöben.}

1763. II. F. Ledermïller, Mikroskopisehe Augen- und Gemüthsergötzungen. Nïrnberg.

1835. Dujardin, Observations sur les Rhizopodes. Comptes rendus 1835. Histoire naturelle des zoophytes. Paris. 1841. - Articl. Rhizopodes in Diction. univers. d'histoire natur. Paris. Vol. XI. 1848.

1838. Ehrenberg, Die Infusionsthierchen als vollkommene Organismen. 1838. Leipzig. - Ueber noch jetzt zahlreich lebende Thierarten der Kreidebildung und den Organismus der Polythalamien. Abhandl. der Academie zu Berlin 1839. - Uebersicht der seit 1847 fortgesetzten Untersuchungen über d. von der Atmosphäre unsichtbar getragene Leben. Abh. d. Berl. Acad. aus dem Jahre 1871. Berlin. 1872.

1\$44. d'Orbigny, Articl. Foraminifères in Dict. univ. d'hist. natur. 'T. V. 1884. S. 662 .

1852. M. Perty, Zur Kenntniss der Kleinsten Lebensformen in der Schweiz. Bern. 1852.

1854. Max Sigm. Schultze, Ueber den Organismus der Polythalamien nebst Bemerkungen über die Rhizopoden im Allgemeinen. Leipzig.

1856. Lieberkïhn, Zeitschr. f. wissensch. Zoologie. 1856. Bd. VIII. - Acad. belgique. Mémoires des savants étrangers. Tome XXVI. Fol. XI.

"L. A uerbach, Ueber die Einzelligkeit der Amoeben. Zeitschr. f. wissensch. Zool. Bd. VIl. 1856. p. 391. - Amoeba bilimbosa ibid. S. 274.

1858. W. C. Williamson, On the recent Foraminifera of Great-Britain. London. 1858.

1858 - 1861. Claparède und L a chman n, Études sur les Infusoires et les Rhizopodes. 2 vol. Genève.

1859. Parker and Jones, On the nomenclature of the Foraminifera. Ann. mag. nat. hist. 1859 u. ff. Part. I-XV.

1861. Reuss, Entwurf einer systematischen Zusammenstellung der Foraminifera. Wien 1861. Sitzungsber. d. k. k. Acad. d. Wissenseh. zu Wien.

1862. Carpenter, Introduction to the Study of the Foraminifera. Roy. Society. London.

1864. H. B. Brady, On the rizopodal-fauna of the Shetlands Transact Linnean. soc. T. XXIV. 1864 - of the Hebrids. Rejort. Brit. Assoc. Nottingham Meeting 1866. - The foraminifera of tidal rivers. Ann. mag. nat. hist. 3 ser. T. VI. 1870. - Notes on some Reticularian Rhizopoda of the "Challenger" expedition. I. On new or little known arenaceous types. Qu. journ. of mierose. sc. No. 5. Bd. XIX. II Addit. to the knowledge of porcellanous and hyal. typ.

1867. Waldenberg, Mrch. f. path. Anat. Bd. 40. S. 438.

1868. G. Haeckel, Das Protistenreich. Monographie der Moneren. Jena. Zeitschr. f. Ned. u. Naturk. Bd. IV. 1868. - Ueber den Sarcodekörper 
der Rhizopoden. Zeitschr. f. wissensch. Zool. Bd. XV. 1865. - Zur Morphologie der Infusorien. 1873 etc.

1872. Jahresberichte der Commission zur wissenschaftlichen Untersuchung der deutschen Meere in Kiel für das Jahr 1872-1873. II. I. III. Jahrg. 1875. F. E. Schultze, Rhizopoden der Nord- und Ostsee.

1874. F. E. Schulze, Rhizopodenstudien. Arch. f. mikrosk. Anat. I. u. II. Bd. X. 1874. III. u. IV. Bd. XI. 1875. Bd. XIII. 1877 etc.

R. Hertwig und Lesser, Ueber Rhizopoden und denselben nahestehende Organismen. Arch. f. mikr. Anat. 1874. Bd. X. Supplement. Süsswasserformen. - R. Hertwig, Bemerkungen zur Organisation und systematischen Stellung der Foraminifera. Jena. Zeitschr. f. Med. u. Naturwissensclı. Bd. X. 1876.

") J. Leidy, Proceedings of the Acad. of natur. scienc. of Philadelphia 1874. u. 1577 etc.

Frommentel, Étndes sur les milirozoaires. Paris.

1876. Maggi, Atti dell' Instituto Lombardo. 1876.

" L. Cienkowsky, Ueber einige Rhizopoden und verwandte Organismen. Arch. f. mikrosk. Anat. Bd. XII. 1876.

" Archer, Résumé of recent contributions to the knowledge of freshwater Rhizopoda. - Qu. journ. microsc. XVl п. XVII. 1876-1877.

1877. B. Ey ferth, Die mikroskopischen Süsswasserbewohner. Braunschweig.

1878. von Mereschkowsky, Amoeba jelaginia. Arch. f. mikr. Anat. 1875. Bd. XI. S. 592. -- Studien über die Protozoen des nördlichen Russlands. Arch. f. mikr. Anat. XVI. p. 204. 1878.

A im. Sehneider, Sur les rhizopodes terrestres. Rér. scientif. 1878.

1879. Leuckart, Die Parasiten des Menschen. Jeipzig. 1879-90 etc.

18S0. A. Gruber, Der Theilungsvorgang bei Englypha alveolata, die Theilung der monothalamen Rhizopoden. Untersuchungen über einige Protozoen, über Kerntheilungsvorgänge bei einigen Protozoen. Zeitschr. f. wissensch. Zool. Bd. XXXY-XXXVlII. - Studien über Mmöben. Zeitsch. f. wissensch. Zool. Bd. 41. 1885 .

1882. Lanessan, Traité de zoologique. I. Protozoaires.

, Zürn, Die Schmarotzer auf und in dem Körper unserer Hausthiere. II. Aufl. Weimar. 1882-1887.

1883. G. Klebs, Ueber die Oryanisation einiger Flagellatengruppen und ihre Beziehungen'zu Algen und Infusorien. 1883.

1884. A. Brass, Die thierischen Parasiten des Menschen. Cassel.

"Balbiani, Études sur Ia reproduction des Protozoaires. Journ. de Ia phys. Tom. HI. Leçons sur les sporozoaires. Paris.

1887. F. Blochmann, Zur Kenntniss der Fortpflanzung von Euglypha alveolata. Morph. Jahrbuch. XIII. 1887.

"W. Schewiakoff, Ueber die karyokinet. Kerntheilung bei Englypha alveolata. Morph. Jahrb. 1887. Bd. XIII.

1888. Neumann-Toulouse, Traité des maladies parasitaires non-microbiennes chez les animaux domestiques. Paris.

1889. H. G. Bronns, Klassen und Ordnungen des Thierreichs in Wort und Bild. I. Bd. Protozoen neu bearbeitet ron O. Bütschli. I. Abth. Sarcodina und Sporozoa. Leipzig u. Heidelberg. C. F. Winter's Verlagsbuchh. 1889. 
und Maladies parasitaires, parasites animaux, parasites végétaux àl'exclusion des Bacteries. Traité de Pathol. génér. T. II. p. 649-932. Paris. 1895.

1890. Baumgarten,. Die pathologische Mycologie. Bd. II. 1890; - ferner Jahresberichte ïber die Fortschritte in der Lebre von den pathogenen Mikroorganismen. $1885 \mathrm{u}$. ff.

1891. L. Pfeiffer, Die Protozoen als Krankheitserreger. II. Aufl. 1891. Jena. G. Fischer etc.

„C. Klaus, Lehrbuch der Zoologie. Marburg 1891. Elwert'sche Buchhdlg.

1892. Verworn, Die Bewegung der lebendigen Substanz. Eine vergleichende physiologische Unters. bei Contractionserscheinungen. Gust. Fischer. Jena.

, R. Hertwig, Lehrbuch der Zoologie. 1892. Jena. Gust. Fischer.

" R. Pfeiffer, Beiträge zur Protozoenforschung. Die Coccidienkrankheit der Kaninchen.

1893. 0. Hertwig, Die Zelle und die Gewebe.

1894. A. Labbé, Recherches zoologiques et biologiques sur les parasites endoglobulaires du sang des Vertébrés. Arch. de zool. expérim. III.Série. T'. Il. p. $55-258$.

" F. Klemperer und E. Lewy, Grundriss der klinischen Bacteriologie. Berlin 1894. A. Hirschwald.

1895. M. Braun, Die thierischen Parasiten des Menschen. 1895. II. Aufl. Würzburg. Adalhert Stubert's Verlagsbuchl.

" Schneidemühl, Lehrbuch der vergleichenden Pathologie und Therapie des Menschen und der Hausthiere. 1895. Leipzig. Wilh. Engelmann.

1896. Dantec et Bérard, Les sporozoaires et particulièrement les coccidies pathogènes. Paris.

" von Wasielcwski, Sporozoenkunde. Jena. Gust. Fischer.

" O. Lubarsch und R. Ostertag, Ergebnisse der allgemeinen Aetiologie der Menschen- und Thierkrankheiten. 1896. Wiesbaden.

\section{b) Specielle Literatur über parasitäre Amöben.}

1849. G. Gros, Fragments d'helminthologie et de physiol. microscop. Bullet. de la soc. Insp. de Natural de Moscou. 1849. I. 2. p. 555.

1860. W. Lambl, Beobachtungen und Studien aus dem Gebiete der patholog. Anatomie und Histologic. Aus dem Franz Josef-Kinderhospital in Prag. 1860. S. 362.

1862. Sternberg, Zeitschrift für neuere Medicin. 1862. No. 20-24. Herausgegeben von Walter in Kiew (russ.).

1869. Rasch, Anatomische und klinische Untersuchungen ïber Dysenterie. Virchow's Arch. Bd. 45. 1869. S. 204.

1870. Lew is, Sixt. ann. rep. san. Commiss. with the Govern. of India, Calcutta 1870.

1870-71. Balsamo-Crivelli und Maggi. Ueber Cultur von Autoamoeba albuminis. Rend. del R. Instituto Lombardo. Serie II. Vol. III u. IV.

1870. Cunningham, Seventh. ann. rep. of the. san. Comm. Govern. of India, Calcutta 1870. - On the development of certain miliroskopic Organism occuring in the intestinal canal. Quart. journ. microsc. sc. XXI. 1881. p. 234. 
1875. F. Loesch, Massenhafte Entwickelung von Amöben im Dickdarm. Virchow's Archiv. Bd. XLV. 1875. S. 196.

1879. B. Grassi, Dei protozoi parassiti e specialmente di quelli che sono nell' nomo (Sunto preventivo). Gazetta medica italian. 1879. p. 45. - Intorno ad alcuni protisti endoparassiti et appartenenti alle classi dei flagellati, lobosi, sporozoi e ciliati. Atti della societa Italiana di scienze naturali. Vol. XXIV. Milano 1882. - Significato patologico dei protozoi parassiti dell'uomo. Atti della Real. Accad. dei Lincei Rendiconti. IV. 1888. p. 83 etc.

" Normand, Note sur deux cas de colite parasitaire. Arch. méd. Nar. XXXII. 1879. p. 211.

1882. Perroncito, Parassiti dell' uomo e degli animali utili. Milano.

1883. E. Baelz, Ueber einige neue Parasiten des Menschen. Berl. klin. Wochenschrift. 1883. S. 237.

1884. Petrone, Nota sull' infezione dissenterica. Lo sperimentale. 1884. Maggio. p. 509.

1885. Kartulis, Ueber Riesenamöben bei chronischer Darmentzündung der Aegypter. Virchow's Arch. XCIX. 1885. S. 145. - Zur Aetiologie der Dysenterie in Aegypten. Virchow's Arch. CV. 1886. S. 521. - Zur Aetiologie der Leberabscesse. Centralbl. für B. und P. II. 1887. No. 25. S. 745. - Ueber tropische Leberabscesse und ihr Verhältniss zur Dysenterie. Virchow's Arch. CXVIII. 1889. S. 97. - Einiges über die Pathogenese der Dysenterieamöben. Centralbl. für B. und P. IX. 1891. No. 11. S. 365. Ueber weitere Verbreitungsgebiete der Dysenterieamöben. Centralbl. für B. und P. VII. 1890. S. 54. - Ueber pathogene Protozoen beim Menschen. Zeitschr. für IIygiene und Infectionskrankh. XIII. 1893. S. 2. -- Amöben im Eiter eines Submaxillarabscesses und im necrotischen Gewebe. Ibid. S. 9. - Dysenterie. V. Bd. III. Abth. in der speciellen Pathol. n. Therap., herausg. von Nothnagel. Wien 1896. Alfred Hoelder.

1887. R. Koch und G. Gaf1ky, Arbeiten aus dem Kaiserl. Gesundheitsamt. ILI. Berlin 1887. Bericht über die 'Thätigkeit der zur Erforschung der Cholera im Jahre 1883 nach Egypten und Indien entsendeten Commission.

" O. Hlava, Ueber die Dysenterie. Zeitschr. für böhmische Aerzte in Prag. 1857. Ref. im Centralbl. f. B. und P. 1887. No. 18 S. 537.

" Ribbert, Ueber einen bei Kaninchen gefundenen pathogenen Spaltpilz. Deutsche med. Wochenschr. 1887. No. 8.

" H. M. Biggs, History of an epidemie of dysentery at the Alonchousc, Blackwells Island, New-York. New-York. med. Journal. 1887. p. 13.

1888. Chantemesse et Widal, Sur le microbe de la dysentérie épidémique. Bullet. de l'Acad. de médécine. 'T. XXX. 1888. p. 522.

1889. Jürgens, Verbandlungen des Vereins für innere Medicin. 1889. Deutsch. med. Wochenschr. 1892. No. 20. S. 454.

"Massiutin, Ueber die Amöben als Parasiten des Dickdarms. Wratsch. 1889. No. 25. Ref. im Centralb]. für B. und P. 1889. S. 451.

1890. W. Osler, Ueber die Dysenterie und im dysenterischen Leberabscess vorhandene Amöben. Centralbl. für B. und P. 1890. No. 23. S. 736 . Johns Hopkins Hospit. Bullet. Vol. I. 1890. No. 5. S. 53.

"Calandruccio, Animali parassiti dell' nomo in Sicilia. Atti dell' Accademia Gioenia. Serie IV. Vol. II. 1890. S. 95. 
1890. J. Fenoglio, Entéro-colite par Amoebe coli. Arch. italiennes de médecine. T. XIV. 1890. p. $62-70$.

$" \quad$ Musser, University medical Magazine. Vol. IlI.

"Simon, John Hoplins Hospital Bulletin. 1890.

$" \quad$ A. Stengel, Acute Dysentery and the Amoeba coli. Philadelphia medical. News 1890 Nov. p. 500. - The amoeba coli. Unirersity medical Magazine. 1892 January.

1891. Nasse, Ueber einen Amöbenfund bei Leberabscess und Dysenterie. Deutsche med. Wochenschr. 1891. S. 881.

" W. P. Councilman and II. A. Lafleur. Amoebic dysentery. John Hopkins Hospital Reports 1891. II. p. 395-548. Ref. im Centralbl. für B. und P. 1892 . p. 524.

" Riva, Amöbenculturen, Lavori dei Congressi di medicina internat. IV. Congresso tenuta a Roma nel 1891.

" E. Cahen, Ueber Protozoen im kindlichen Stuhle. Dentsche med. Wochenschrift. 1891. No. 27. p. 853 .

" A. Lutz, Zur Kenntniss der Amöben bei Enteritis und Hepatitis. Centralblatt für B. und P. Bd. X. 1851. No. 8. S. 241.

" G. Dock, Observations on the Amoeba coli in Dysentery and abscess of the liver. Daniel's 'lexas medical Journal. 1891. p. 419-431.

"Eichberg, Hepatic abscess and the Amoeba coli. 'Tlue medical News. Vol. LIX. 1891. No. 8. p. 201.

1892. Flexner, Amoebae in an abscess of the jaw. Johns Hopkins Hospital. Bulletin No. XXV. Sept. 1892. Ref. im Centralblatt für B. und P. XIV. 1893. p. 288.

" Ogata, Zur Aetiologie der Dysenterie. Centralbl. für B. und P. Bd. Xl. 1892. No. 9-10. S. 264. - Ueber dic Reincultur gewisser Protozoen (Infus.). Centralbl. für B. und P. Bd. XIV.. 1893. No. 6. S. 165.

"J. Kovács, Beobachtungen und Versuche über die sogenannte Amöbendysenterie. Zeitschr. f. Heilkunde. Bd. XIII. 1892. p. 509. Referat in Baumgarten's Jahrbücher. Bd. VIII. 1892, p. 425 u. Centralbl. f. allgem. Pathol. 1893. No. 3. p. 119.

" Wesener, Unsere gegenwärtigen Kenntnisse über Dysenterie in anatomischer und ätiologischer Hinsicht. Centralbl. f. allgem. Patholog. Bd. III. 1892. No. 12. p. 484 u. No. 13. p. 529.

" A. Maggiora, Einige mikroskopische und bakteriologische Beobachtungen während einer epidemisch-dysenterischen Darmentzündung. Centralbl. f. Bakteriol. u. Parasitenk. Bd. XI. 1892. No. 6-7. p. 123.

" E. Zieg]er, Handbuch d. speciell. path. Anatomie. 7. Anfl. G. Fischer. 1892. p. 544 .

$" \quad$ Harold, Case of Dysentery with Amoeba coli in the stools. British med. Journal. 1892. Vol. II (31. X1I.). p. 1429.

"W. Janowski, Kritische Uebersicht der Methoden der Behandlung der Dysenterie. Kronika Lekarslia. 1892. No.12. p.783. - Ueber Flagellaten im menschlichen Stuhl und ihre Bedeutnng in der Pathologie des Darıncanals. - Zur Aetiologie der Dysenterie. Centralbl. f. B. u. P. 1897. XXI. Bd. No. 3. p. 88. No. 4. p. 151. No. 5. p. 194. No. 6, 7. p. 234.

1893. Zancarol, Pathol. des abscès du foie. Revue de chirurg. 1893. No.8. Dysent. tropicale et abscès du foie. Le progrès méd. 1895. No.24. p. 393. 
1893. A. Schuberg, Die menschliche Amöbe des Dickdarms. Centralbl. f. B. u. P. Bd. XIII. 1893. No. $18-22$.

C. Posner, Ueber Amöben in Harn. Berliner klin. Wochenschr. Jahrgang XXX. 1893. No. 28. p. 674.

H. Quincke und G. Roos, Ueber Amöbenenteritis. Berl. klin. Wochenschrift. 1893. No. 45. p. 1089.

Kruse und Pasquale, Eine Expedition nach Aegypten zum Studium der Dysenterie und des Leberabscesses. Deutsche med. Wochenschrift. 1893. No. 15. p. 354. No. 16. p. 378. - Untersuchungen ïber Dysenterie und Leberabscess. Zeitschr. f. Hygiene. 1894. p. 1-148.

" Laveran, Étiologie de la dysentérie. Sem. méd. 1893. p. 508.

L. Bertrand et Baucher, Nouvelle étude bactériologique des selles dans la dysentérie nostras epidémique. Gaz. hebd. 1893. No.40. p. 474.

A. Ebstein, Beobachtungen über Cercomonas hominis und Amoeba coli. Prager med. Wochenschr. 1893. p. 38-40.

$" \quad$ F. Schardinger, Reincultur der Amöben auf festem Nährboden. Centralblatt f.. B. u. P. Bd. XIII. 1883. No. 18-22. - Protozoenculturen. Nachtrag. Centralbl. f. B. u. P. Bd. XXII. No. 1, 3.

1594. E. Roos, Zur lienntniss der Amöbenenteritis. Arch. f. experim. Pathol. u. Pharmak. Bd. 33. 1894. p. 389.

" Rossi Doria, Amöbenbefund bei Endometritis chronica glandularis. Arch. f. Gynäk. Bd. 47. Heft I.

N. Lobas, Aus der Casuistik der amöb. Erkrankung. Wratsch. 1894. No. 30. p. 845 .

Piccardi, Amöbenculturen. R. Accad. di med. di Torino. Sed. del. 14. Dic. 1894 und Aleuni protozoi delle feci dell'uomo. Giornale della reale Accademia di medicina di Torino. Vol. I. 1895. Fasc. 3-4. M. Tivaldi, Le amebe della dissenterica. La riforma medica. Anno X. 1894. No. 238.

F. Berndt, Protozoen in einem Leberabscess. Dentsche Zeitschr. f. Chir. Bd. 40. 1894. Heft 1 u. 2. p. 163.

E. Silvestri, Contributo allo studio dell'etiologia della dysenteria. La riforma medica. 1894. No. 22.

0. Arnaud, Recherches sur l'étiologie de la dysentérie aiguë des pays chauds. Annal. d'Inst. Pasteur. 1894. No. 7. p. 495.

Ma dan, La disentéria en Playa de Indios. Crónica med. quirurgica de la Habana. 1894. p. $395-405$.

$" \quad$ C. O. Miller, Ueber aseptische Protozoenculturen und die dazu verwendeten Methoden. Centralbl. f. B. u. P. Bd. XVI. 1894. No. 7.

A. Celli und R. Fiocca, Beiträge zur Amöbenforschung. Centralbl. f. B. u. P. Bd. XV. 1894. No. 13-14. p. 470. - Contributo allo cognoscenza della vita delle amebe. La riforma medica. 1894. No. 187, p. 435 und Centralbl. f. B. u. P. Bd. XVI. 1894. No. 8-9. p. 329 . -- Ueber die Aetiologie der Dysenterie. Centralbl. f. B. u. P. Bd. XVII. 1895. No. 9 u. 10. p. 309. - Intorno alla biologia delle amebe. Bulletino della R. Academia medica di Roma. Anno XXI. 1894-1895. Fascicolo V. Roma. Abgekürzt Deutsch. Centralbl. f. B. u. P. Bd. XIX. 1896. No. 14 u. 15. p. 537. - Atti dell'Accademia. Gioenia di Catania. Seduta del 24. Nov. 1895. p. 537. 
1894. Mosler und Peiper, Specielle Patholog. u. Therapie, herausgegeben von Nothnagel. Bd. VI. Wien.

1895. Lind ner, Mikroskopische Betriebscontrolle im Gährungsgewerbe. 1895. p. 35. J. Gasser, Notes sur les causes de la dysentérie. Arch. de méd. expérim. No. 2. Mars 1895. p. 198.

" Casagrandi e Barbagallo-Rapisardi, Sull'amoeba coli Loesch, ricerche biologiche e clinice. Accad. Gioenia di science natural. di Catania. Seduta del 27. I. Catania 1895. 8. p. 15 und seduta del 24. X1. 1895. p. 13. - Ueber die Cultur von Amöben. Centralbl. f. B. u. P. Bd. XXI. 1897. No. 24 u. 25. p. 926.

$" \quad$ Bosco und Perroncito, Amöbenculturen. K. Accad. di med. di Torino. Sed. del 29. Nor. 1895 u. 10. Genn. 1896.

"V. Babes et V. Figura, Étude sur l'entéro-hépatite suppurée endemique. Annales de l'Instit. de pathol. et de Bactériol. de Bucarest. 1895. p.211-255.

" John Carnow, Hepatic abscess followed by amoebic dysentery, operation, recovery. Lancet. 1895. Vol. I. No. 3740. May. p. 1109.

" R. Monti, Cultur von Amöben. Bolletino scientifico. No. 1. Pavia Marzo. 1895 u. Arch. Ital. de Biologie. 1895. p. 174.

1896. Rendu, Deux cas d'abscès tropicaux du foie. Sem. méd. 1896. To.36.p. 285.

" F. Fajardo, Ueber amöbische Hepatitis und Enteritis in den Tropen (Brasilien). Centralbl. f. B. u. P. Bd. XIX. 1896. No. 20. p. 753.

" A. Celli, Eziologia della dissenteria. Ne' suoi Rapporti col B. Coli e colle sue Tossine. Annali d'Igiene sperimentale. Vol. VI. Fascicolo II. 1896.

" J. Boas, Ueber Amöbenenteritis. Deutsche med. Wochenschrift. No. 14. p. 214-218.

" Borchardt, De l'entérite amébienne. Sem. méd. 1896. No. 11. p. 87.

"F. Manner, Ein Fall von Amöbendysenterie und Leberabscess. Wiener klin. Wochenschr. 1896. No. 8 u. 9.

" Peyrot et Roger, Abscès dysentérique du foie arec amèbes. La médic. moderne. 1896. p. 232. Ref. im Centralbl. f. Bact. u. P. Bd. XX. 1896. No. 22 u. 23. p. 815.

E. Cramer, Neuere Arbeiten über Tropenruhr oder Amöbendysenterie. Centralbl. f. allgemeine Pathol. Bd. VII. 1896. No. 4. p. 138.

". M. W. Beyerinck, Culturversuche mit Amöben auf festem Substrate. Centralbl. f. B. u. P. Bd. XIX. 1896. No. 18. p. 25\%. - Amöbencultur auf festem Snbstrate. Centralbl. f. B. u. P. 1897. Bd. 21. No. 3. p. 101. " Gorini, Die Cultur der Amöben auf festem Substrate. Centralbl. f. Bact. Bd. XIX. 1896. No. 20. p. 785.

" Leyden und Schaudinn, Leydenia gemmipara Schaudinn, ein neuer in der Ascitesflüssigkeit des lebenden Menschen gefundener amöbenartiger Rhizopode. Sitzungsberichte der Königl. Preuss. Acad. d. Wissenschaften zu Berlin. Bd. 39. 1896. p. 13.

1897. P. Frosch, Zur Frage der Reinzüchtung von Amöben. Centralbl. f. B. u. Bd. XXI. 1897. No. 24 u. 25. p. 926. 


\section{Erkliirung der Tafel.}

Figur 1. Amoeba proteus, nach Leidy. $\mathrm{n}=$ Kern, $\mathrm{cr}=$ contractile Vacuole, $\mathrm{N}=$ Nahrungsballen, en $=$ Körnerplasma, ek = Hautplasma.

Figur 2. Amoeba (Dactylosphaera) polypodia, nach F. E. Schulze. $\mathrm{N}=\mathrm{Nu-}$ cleus, $\mathrm{Pv}=$ pulsirende Vacuole.

Figur 3. Hyalosphenia lata, nach Rawitz. $1=$ Kern, $2=$ Vacuolen.

Figur 4. Amoeba spinosa, nach Celli and Fiocea.

Figur 5. Difflugia oblonga, nach Stein. $\mathrm{p}=$ Pseudopodien, $\mathrm{n}=$ Nucleus.

Figur 6. Amoeba blattarum, aus dem Darm von Blatta orientalis, nach L. P feiffer.

Figur 7. Amoeba Limax, aus dem Darm von Limax, nach L. Pfeiffer.

Figur 8. Amoeba spinosa, nach Celli nnd Fiocca.

Figur 9, 10, 11. Amoeba arborescens in Ruhe- (10) und Cystenstadium (11), nach Celli und Fioeca.

Figur 12. Amoeba coli Loesch im Darmschleim mit Blut- und Eiterkörperchen. Nach L Iösch.

Figur 13. Strohamöben, aus einem Strohinfus nach eigener Zeichnung.

Figur 14. Amoeba intestinalis vulgaris, mit Ruhe- und Cystenstadium, nach eigener Zcichnung, aus dem Darm cines Gesunden, nach Bitterwasser.

Figur 15. Sporenkeimung von Amoeba nitrophila Beyerinck. $\mathrm{N}=$ Zellkern, $\mathrm{P}=$ pulsirende Vacuole, $\mathrm{n}=$ Nebenvacuolen, en $=$ Endospor.

Figur 16. Amoeba zymophila, nach Beyerinck, mit eingeschlossenen Essigbakterien, diese theilweis in Nahrungsvacuolen. Kern sehr deutlich. $\mathrm{N}=$ Zellkern, $\mathrm{r}=$ ruhende Vacuole.

Figur 17. Apiculatushefe mit Amoeba zymophila, nach Beyerinck. $v=$ ruhende Vacuole.

Figur 18. Strich e von Essigbakterien mit Schleier z Amoeba zymophila auf Nährgelatine, nach Beyerinck.

Figur 19. Junge Amöben sich theilend in den Stadien $\alpha \beta \gamma$. Bei $\gamma$ pulsirende Vacnole mit Nebenvacuolen sichtbar. $\mathrm{p}=$ pulsirende Vacuole, $\mathrm{n}=$ Nebenvacnole. Nach Beyerinal.

Figur 20. Amoeba nitrophila, nach Beyerinck. $\mathrm{N}=$ Zellkern, $\mathrm{v}=$ ruhende Vacuole, $\mathrm{p}=$ pulsirende Vacuole.

Figur 21. Essigbakterien mit Amoeba zymophila. $\mathrm{N}=$ Zellkern, $\mathrm{v}=$ ruhende Vacuole. Nach Beyerinck.

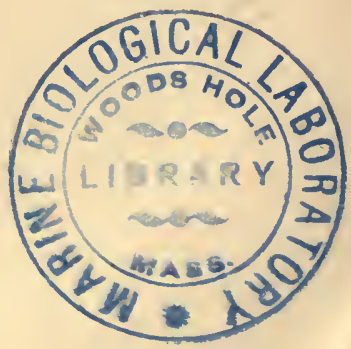





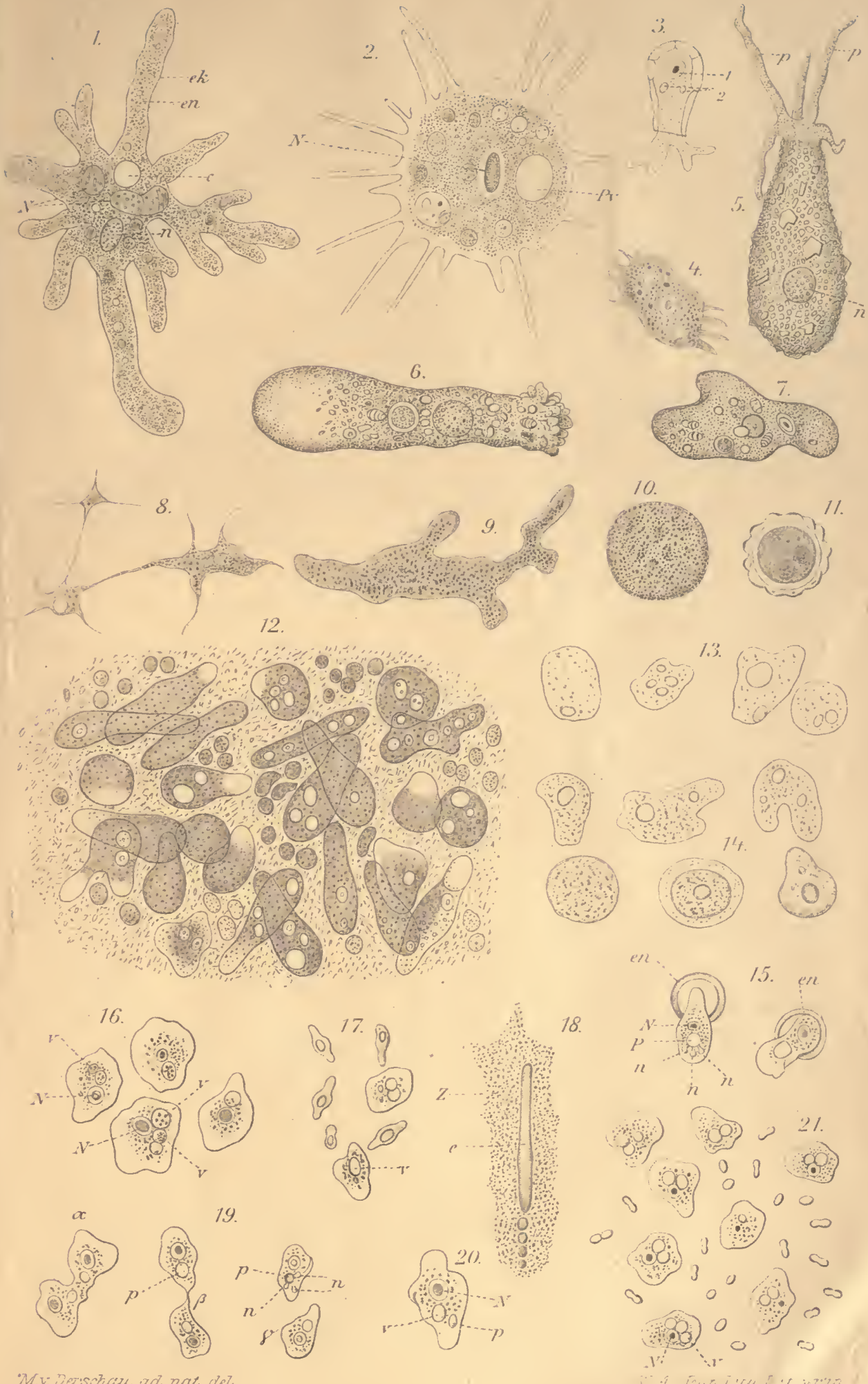




Verlag von August Hirschwald in Berliu.

\title{
Mikrophotographischer
}

\section{Atlas der Bakterienkunde}

\author{
von Prof. Dr. C. Vräukel und Prof. Dr. R. Pfeiffer.
}

Zweite Auflage. In 15 Lieferungen. 1895. gr. 8. à Lfg. 4 M.

Preis des vollständigen Atlas elegant in Leder gebd. $62 \mathrm{M}$.

\section{Die Hefen als Krankheitserreger} ron Privatdocent Dr. O. Busse.

1897. gr. 8. Mit 2) Bunttafeln und 9 Eiguren.

Preis 3 M. 60 Pf.

\section{Beiträge zur P'rotozoen-Forschung} von Professor Dr. R. Preifter.

1. Heft. Die Coccidienkrankheit der Kaninchen.

1892. gr. S. Mit 12 mikrophotogr. Tafelı. $10 \mathrm{M}$.

\section{Die mikroskopische Diagnose}

\section{der bösartiogen (a)chwiilste}

von Prof. Dr. b. Hansemann.

1897. gr. S. Mit S3 Fig. 7 Mark.

\section{Practicum \\ der pathologischen Histologie.}

Leitfaden für Studirende und Aerzte vun Professor Dr. Oskar Israel. Zweite vermehrte Auflage.

1893. gr. \&. M. $15 \mathrm{~S} A \mathrm{bb}$. und 7 Taf. I'reis $15 \mathrm{M}$.

Pathologisch-anatomische Diagnostik

ncbst Anleitung zur Ansführung von Obductionen sowie von pathologisch-histologischen Untersuchungen von Prof. Dr. Joh. Orth.

F ïnfte neu bearb. Aufl. 1S94. gr. 8 . Mit +10 Abbildungen. $16 \mathrm{M}$.

\section{Hundert Jahre allgemeiner Pathologie.} von Rurlalf Virehuw. 1895. gr. S. 1 Mark.

\section{Die Sections-Technik}

in Leichenhause des Charité-Krankenhauses, mit besonderer Rüchsicht auf gerichlsäıztliche Praxis erürtert von

Rudolf Virchow.

Im Auhange: Das Regulativ für das Verfahren der Gerichtsärzte ete.

Vierte Auflage. gr. 8 . Mit 4 Abb. im Text. 1S93. $3 \mathrm{M}$. 

